KARINA RIBEIRO DA SILVA

\title{
INVESTIGAÇÃO DAS BASES MOLECULARES DA \\ IMUNODEFICIÊNCIA PRIMÁRIA DA PROTEÍNA \\ C3 DO SISTEMA COMPLEMENTO HUMANO
}

Dissertação apresentada ao Programa de Pós-

Graduação em Imunologia do Instituto de

Ciências Biomédicas da Universidade de São

Paulo, para obtenção do Título de Mestre em

Ciências.

Área de concentração: Imunologia

Versão original

São Paulo

2014 
KARINA RIBEIRO DA SILVA

\section{INVESTIGAÇÃO DAS BASES MOLECULARES DA IMUNODEFICIÊNCIA PRIMÁRIA DA PROTEÍNA C3 DO SISTEMA COMPLEMENTO HUMANO}

Dissertação apresentada ao Programa de Pós-Graduação em Imunologia do Instituto de Ciências Biomédicas da Universidade de São Paulo, para obtenção do Título de Mestre em Ciências.

Área de concentração: Imunologia

Orientadora: Prof $^{\mathrm{a}} \mathrm{Dr}^{\mathrm{a}}$ Lourdes Isaac

Versão original

São Paulo

2014 
DADOS DE CATALOGAÇÅO NA PUBLICAÇÃo (CIP)

Serviço de Biblioteca e Informação Biomédica do

Instituto de Cièncias Biomédicas da Universidade de São Paulo

reproduçăo nåo autorizada pelo autor

\section{Silva, Karina Ribeiro da.}

Investigação das bases moleculares da imunodeficiência primária da proteína C3 do sistema complemento humano / Karina Ribeiro da Silva. - São Paulo, 2014.

Orientador. Profa. Dra. Lourdes Isaac.

Dissertaçäo (Mestrado) - Universidade de Säo Paụlo. Instituto de Ciências Biomédicas. Departamento de Imunologia. Área de concentraçäo: Imunologia. Linha de pesquisa: Sistema complemento.

Versäo do título para o inglès: Investigation of molecular basis of the primary immune deficiency $\mathrm{C} 3$ protein of the human complement system.

1. Sistema complemento 2. C3 3. Imunodeficiência 4. Deficiência de C3 5. Deleçäo de éxon 6. Mutaçäo I. Isaac, Profa. Dra. Lourdes II. Universidade de Säo Paulo. Instituto de Ciências Biomédicas.

Programa de Pós-Graduação em Imunologia III. Título. 
UNIVERSIDADE DE SÃO PAULO

INSTITUTO DE CIÉNCIAS BIOMÉDICAS

\begin{abstract}
Candidato(a):
Karina Ribeiro da Silva.

Título da Dissertação

Investigação das bases moleculares da imunodeficiência primária da proteína C3 do sistema complemento humano.
\end{abstract}

Orientador(a):

Profa. Dra. Lourdes Isaac.

A Comissão Julgadora dos trabalhos de Defesa da Dissertação de Mestrado, em sessão pública realizada a ... ..... considerou

( ) Aprovado(a)

( ) Reprovado(a)

Examinador(a):

Assinatura:

Nome:

Instituição:

Examinador(a): $\quad$ Assinatura:

Nome:

Instituição:

Presidente: Assinatura:

Nome:

Instituição: 
UNIVERSIDADE DE SÄO PAULO

INSTITUTO DE CIÊNCIAS BIOMÉDICAS

Cidade Universitária "Armando de Salles Oliveira"

Av. Prof. Lineu Prestes, 2415 - cep. 05508-000 Săo Paulo, SP - Brasi

Telefone :(55) (11) 3091.7733 telefax : (55) (11) 3091-840

e-mail: cep@ icb.usp.b

São Paulo, 10 de outubro de 2012.

\section{PARECER 1080/CEP}

A Comissão de Ética em Pesquisas em Seres Humanos do ICB, nesta data APROVOU O projeto intitulado: "Investigação das bases moleculares da imunodeficiência primária da proteína c3 do sistema complemento humano" dos autores Profa. Dra. LOURDES ISAAC e aluna KARINA RIBERIO DA SILVA.

Cabe os Pesquisadores executantes elaborarem e apresentar a este Comitê, relatórios anuais (parciais ou final ), de acordo com a resolução 196/06 do Conselho Nacional da Saúde, item IX. 2 letra c.

O primeiro relatório deverá ser encaminhado à Secretaria deste CEP em 10.10.2013.

Atenciosamente,

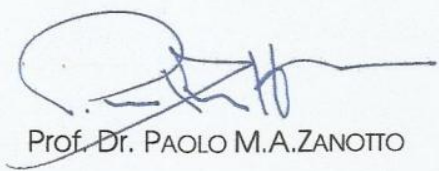

Coordenador da Comissão de Ética em

Pesquisas com Seres Humanos - ICB/USP

Comissão de Ética em Pesquisa com Seres Humanos do Instituto de Ciências Biomédicas / USP Aprovada pela Comissão Nacional de Ética em Pesquisa - CONEP, em 10 de fevereiro de 1998. 


\section{AGRADECIMENTOS}

Agradeço a minha mãe, a sra Eliana Chagas por ter me dado a vida, pelo apoio e paciência desde o início da faculdade até hoje, e por todas as orações para que tudo desse certo. A minha irmã Flávia Regina por todo apoio, ao meu namorido Rosemberg de Jesus Farias que esteve ao meu lado nos momentos difíceis e me fez sorrir deixando as coisas mais fáceis, obrigada pela compreensão. Tenho um agradecimento especial á professora, escritora, palestrante, vizinha, amiga, madrinha e segunda mãe, sra Dora de Amarante Romariz por estar presente na minha família, e na minha vida desde meu nascimento, por me ajudar no pior momento da minha vida me estendendo a mão e colaborando ativamente na minha formação, sem sua ajuda seria impossível realizar esse sonho, saiba que nunca vou te esquecer e que reside eternamente em meu coração.

Gostaria de agradecer a Profa Dra Lourdes Isaac pela orientação e pela confiança no desenvolvimento desse trabalho, por dividir seu conhecimento e parte de sua vida na minha formação profissional, foram três anos dos quais nunca me esquecerei, muitos momentos bons e alguns momentos ruins que fizeram parte do meu crescimento individual, afinal nas adversidades é que aprendemos, se você não cai não aprende a levantar, certo!

Agradeço também a todos os colegas do laboratório de complemento, Adriana Patrícia Martinez Granado, Íris Arantes de Castro, Leandro Dantas Breda, Lorena Bavia, Marlene Pereira de Carvalho Florido, Mónica Marcela Castiblanco Valencia, Tatiana Rodrigues Fraga. Eu aprendi muito com todos e esse trabalho tem um pedacinho de cada um de vocês que me ajudaram e estiveram ao meu lado.

Meus agradecimentos também a todos os demais professores do Instituto de Ciências e Biomédicas da USP, pelas aulas e discussões de trabalhos que auxiliaram no meu aprimoramento e desenvolvimento profissional.

Agradeço também a Luci Deise Navarro e ao Instituto de Química pelo sequenciamento das minhas amostras e rápida prontidão na entrega dos resultados. 
Aos colegas de trabalho e amigos do Instituto Pasteur como Adriana Candido Rodrigues por ouvir meus desabafos, a Juliana Galera Castilho Kawai pelo ajuda no sequenciamento das amostras, a Andreia de Cássia Rodrigues da Silva pelas inúmeras trocas de horário para conclusão desse trabalho.

Agradeço também as agências Fapesp e CNPq pelo auxílio financeiro fornecido durante toda a execução deste projeto.

Mais uma vez, muito obrigada a todos! 
"Quando seus esforços forem visto com indiferença, lembre-se que o sol dá um espetáculo todas as manhãs e muitos continuam dormindo". Autoria desconhecida. 


\section{RESUMO}

Silva KA. Investigação das bases moleculares da imunodeficiência primária da proteína C3 do Sistema Complemento Humano. [dissertação (Mestrado em Imunologia)]. São Paulo: Instituto de Ciências e Biomédicas, Universidade de São Paulo; 2014.

O sistema complemento participa da imunidade natural e da imunidade adquirida. Este sistema pode ser ativado por três diferentes vias: a via clássica, a via alternativa e a via das lectinas, desencadeando uma cascata proteolítica que irá resultar na possível eliminação de microorganismos e, por sua vez, no restabelecimento da homeostasia do indivíduo. A proteína C3 possui um papel central participando das três vias deste sistema. Sua clivagem gera fragmentos que estão associados a várias funções biológicas como opsonização, quimiotaxia, anafilatoxinas, além da formação da C3-convertases, que amplificam a via de ativação efetora contra patógenos. A completa deficiência de C3 é rara, está comumente associada a repetidas infecções, ao desenvolvimento de doenças mediadas por imunocomplexos e glomerulonefrite. Neste trabalho nós investigamos as bases moleculares desta deficiência em uma paciente com histórico de consanguinidade. Nosso estudo identificou uma mutação genética responsável pela completa deleção do éxon 27, implicando na perda de 99 nucleotídeos (região 3450 até 3549 correspondente ao cDNA do C3). O sequenciamento do gene $C 3$ da região 6690313 até 6690961 mostrou uma troca de nucleotídeos $\mathrm{T}$ por um $\mathrm{C}(\mathrm{T} \rightarrow \mathrm{C})$ na posição 6690626 , causando a exclusão do o éxon 27 e deficiência da proteína $\mathrm{C} 3$ do complemento humano nessa paciente. Também confirmamos o padrão de herança autossômica recessiva desta deficiência. Verificamos ainda que os fibloblastos da paciente estimulados com LPS por $24 \mathrm{~h}$ foram incapazes de secretar a proteína C3, o que nos leva a suspeitar que esta proteína mutante seja rapidamente degradada ainda dentro da célula, impedindo sua liberação para o meio extracelular.

Palavras-chave: Sitema Complemento. Deficiência de C3. Exclusão de éxon. 


\begin{abstract}
Silva KA. Investigation of molecular basis of the primary immune deficiency C3 protein of the human complement system. (Mestrado em Imunologia). São Paulo: Instituto de Ciências e Biomédicas, Universidade de São Paulo; 2014.

The complement system participates in the natural immunity and acquired immunity. This system can be activated by three different pathways: the classical pathway, the alternative pathway and the lectin pathway, triggering a proteolytic cascade that will possibly result in the elimination of microorganisms and, in turn, in restoring the homeostasis of the individual. The $\mathrm{C} 3$ protein has a central role in the activation of all pathways. Its cleavage produces fragments that are associated with various biological functions such as opsonization, chemotaxis, and production of anaphylatoxins. In addition, the $\mathrm{C} 3$ participates in formation of $\mathrm{C} 3$ convertase of the alternative pathway which amplifies the activation of effector against pathogens. The complete C3 deficiency is rare and commonly associated with recurrent infections, development of diseases mediated by immune complexes and glomerulonephritis. In this work, we investigated the molecular basis of this deficiency in a patient family with a history of consanguinity. Our study has identified a genetic mutation responsible for the complete deletion of exon 27, resulting in the loss of 99 nucleotides (region 3450 to 3549 of the cDNA corresponding to C3). The sequencing of the $C 3$ region 6690313 to 6690961 showed a $\mathrm{T}$ nucleotide exchange to $\mathrm{C}(\mathrm{T} \rightarrow \mathrm{C})$ at position 6690626 causing deletion of exon 27 leading to deficiency of the human complement protein C3 in this patient. We also confirmed the autosomal recessive patters of this patient deficiency in the family. We observed that patient fibroblasts stimulated with LPS for $24 \mathrm{~h}$ were unable to secrete C3, which leads us to suspect that this protein is degraded within the cell preventing its release into the extracellular.
\end{abstract}

Keywords: Complement system. C3 deficiency. Exon skipping. 


\section{LISTA DE ILUSTRAÇÕES}

Figura 1 - Representação das três vias de ativação do sistema do complemento e a formação do MAC .17

Figura 2 - Representação da ligação tiól-éster encontrada e C3 e C4 do sistema complemento 19

Figura 3 - Formação do MAC 22

Figura 4 - Clivagem e regulação da proteína $\mathrm{C} 3$ do complemento. 29

Figura 5 - Reguladores do complemento...................................................................... 30

Figura 6 - Modelo baseado na estrutura cristalográfica de $\mathrm{C} 3$ humano ……………….......... 32

Figura 7 - Representação esquemáticadas regiões do cDNA de C3 que foram amplificadas e sequenciadas 54

Figura 8 - Heredograma da família objeto de estudo .......................................................... 58

Figura 9 - Análise por Western blotting da presença de C3 nos soros da família ................... 60 Figura 10 - Eletroforese em gel de agarose (1\%) com fragmentos amplificados por RT-PCR62 Figura 11 - Eletroforese em gel de agarose (1\%) com fragmentos amplificados por RT-PCR da

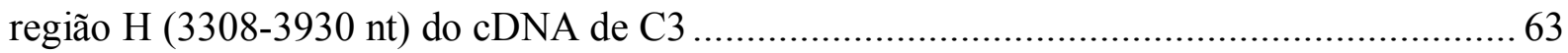

Figura 12 - Sequenciamentodos nucleotídeos do fragmento H de cDNA de C3.................... 64

Figura 13 - Sequenciamento dos nucleotídeos da região 6690313 até 6690961 do gene C3 correspondente aos limites do íntron 27- éxon 27 e éxon 27-íntron 28. 65

Figura 14 - Análise por Western blotting do sobrenadante de fibroblastos estimulados com LPS por $24 \mathrm{~h}$ 66

Figura 15 - Modelo baseado na estrutura cristalográfica de C3 humano ................................ 71

Figura 16-Mecanismo de transcrição, splicing em RNAm e tradução para síntese proteica . 72 Figura 17 - Representação do mecanismo de splicing .......................................................... 74

Figura 20 - Formação de splicing alternativo em eucariotos................................................. 75 


\section{LISTA DE TABELAS}

Tabela 1 - Quantificação das concentrações sérica de C3, C4 e imunoglobulinas ................ 45

Tabela 2 - Contagem diferêncial de leucócitos no sangue da paciente A.S.S .................... 46

Tabela 3 - Iniciadores e posição do nucleotídeos (nt) utilizados para as reações de RT-PCR e reaçao de sequenciamento. 53

Tabela 4 - Quantificação da concentração de proteínas FB, FH, FI e C3 por imunodifusão radial

Tabela 5 - Atividade hemolítica mediada pela via alternativa do sistema complemento ....... 59

Tabela 6 - Atividade hemolítica mediada pela via classica do sistema complemento........... 59

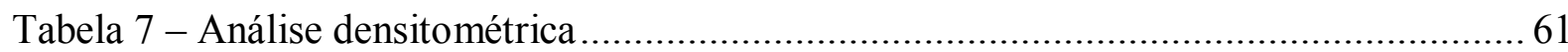




\section{LISTA DE ABREVIATURAS E SIGLAS}

aa -

ANA -

AP50 -

Arg -

$\mathrm{Ca}^{2+}-$

C1INH -

C4BP -

cDNA -

CEPSH -

CH50 -

CPN -

CR-1 -

CR-2 -

CR-3 -

CR-4 -

CUB -

Cys -

DAF -

DEMEN -

DNA -

dNTP -

C3adesArg -

DC -

DAF -

EDTA -

ESE -

ESS -

FB -

FD -

FH -

FI -

Glu -

Gln -

hCG $\beta$ -

HRF -

Ig -

IgG -

IgM -

ISE -

$\mathrm{kDa}$ -

$\mathrm{kb}-$

$\mathrm{kg}-$

aminoácidos

domínio proteico anafilatoxina

ensaio hemolítico da via alternativa do complemento

arginina

cálcio

do inglês $\mathrm{C} 1$-inhibitor

do inglês $\mathrm{C} 4 \mathrm{~b}$-binding protein

DNA complementar

Comissão de Ética em Pesquisa Envolvendo Seres Humanos

ensaio hemolítico da via clássica do complemento

carboxipeptidase

receptor 1 do complemento

receptor 2 do complemento

receptor 3 do complemento

receptor 4 do complemento

domínio proteico de $\mathrm{C} 3$

cisteína

do inglês decay-accelerating factor

Dulbecco's modified Eagle's medium

ácido desoxirribonucléico

desoxirribonucleotídeo trifosfato

$\mathrm{C} 3 \mathrm{a}$ que teve a arginina $\mathrm{C}$-terminal removida por carboxipeptidase $\mathrm{N}$

células dendríticas

do inglês Decay-accelerating factor

do inglês ethylenediamine tetraacetic acid

do inglês exonic splicing enhancers

do inglês Exonic splicing silencers

Fator B

Fator D

Fator $\mathrm{H}$

Fator I

ácido glutâmico

glutamina

gonadotrofina coriônica humana $\beta$

do inglês Homologous restriction factor

imunoglobulina

imunoglobulina $\mathrm{G}$

imunoglobulina $\mathrm{M}$

do inglês intronic splicing enhancers

kilodalton

kilobase

Quilograma 


\begin{tabular}{|c|c|}
\hline $\begin{array}{l}\text { LPS - } \\
\text { MAC - }\end{array}$ & $\begin{array}{l}\text { lipopolissacarídeo } \\
\text { complexo de atague à membrana }\end{array}$ \\
\hline $\begin{array}{l}\text { MAC - } \\
\text { MASP 1/2/ }\end{array}$ & MASP $1 / 2 / 3$ - do inglês mannose-binding lectin associated serine protease $-1 / 2 / 3$ \\
\hline $\begin{array}{l}\text { MASP 1/2/ } \\
\text { MBL - }\end{array}$ & do inglês mannose binding lectin \\
\hline MCP- & proteína cofactor de membrana \\
\hline Mg - & miligrama \\
\hline $\mathrm{Mg}^{++}-$ & magnésio \\
\hline $\begin{array}{l}\text { MG 1-8 - } \\
\text { mL - }\end{array}$ & $\begin{array}{l}\text { domínios de macroglobulinas } 1 \text { - } 8 \text { da proteína } \mathrm{C} 3 \\
\text { mililitro }\end{array}$ \\
\hline $\mathrm{N}-$ & indivíduo normal \\
\hline ng - & nanogramas \\
\hline $\mathrm{nt}-$ & nucleotídeos \\
\hline $\mathrm{NaCl}-$ & cloreto de sódio \\
\hline $\mathrm{NaHCO}_{3}-$ & bicarbonato de sódio \\
\hline NK - & do inglês natural killer \\
\hline NO - & óxido nítrico \\
\hline P - & paciente \\
\hline pb - & pares de base \\
\hline PBS - & do inglês phosphate buffer saline \\
\hline PCR - & reação em cadeia da polimerase \\
\hline PMN - & polimorfonuclear \\
\hline RNA - & ácido ribonucleico \\
\hline RNAm - & ácido ribonucleico mensageiro \\
\hline RT-PCR - & do inglês real time polymerase chain reaction \\
\hline SCR - & do inglês short consensus repeat \\
\hline SDS - & dodecil sulfato de sódio \\
\hline snRNA - & RNA nuclear \\
\hline SLE - & lúpus eritematoso sistêmico \\
\hline Ser - & serina \\
\hline SFB - & soro fetal bovino \\
\hline SFBi - & soro fetal bovino inativado \\
\hline SR - & proteínas reguladoras \\
\hline $\mathrm{T}-$ & timina \\
\hline $\mathrm{TCD}^{+}{ }^{-}$ & linfócito $T$ citotóxico \\
\hline TED - & thioester - containing domain \\
\hline Tris - & Trizma base \\
\hline$\mu \mathrm{g}-$ & micrograma \\
\hline$\mu \mathrm{L}-$ & microlitro \\
\hline$\mu \mathrm{M}-$ & micromolar \\
\hline VEGFR-2 & receptor 2 fator de crescimento endotelial vascular \\
\hline
\end{tabular}




\section{SUMÁRIO}

1 INTRODUÇÃ O

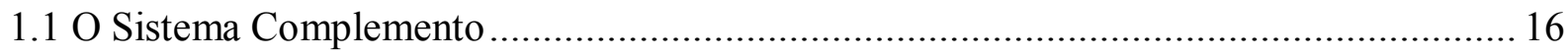

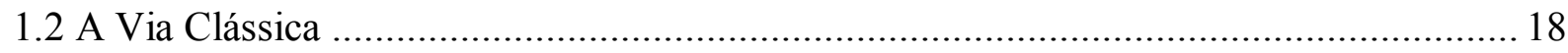

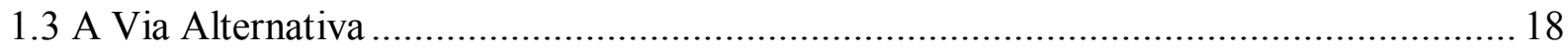

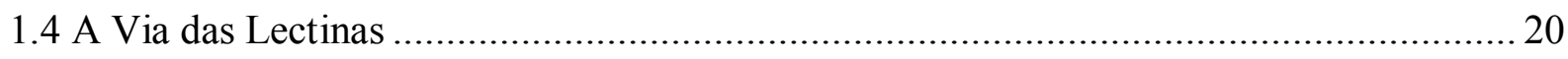

$1.5 \mathrm{MAC}$

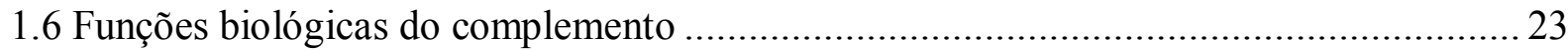

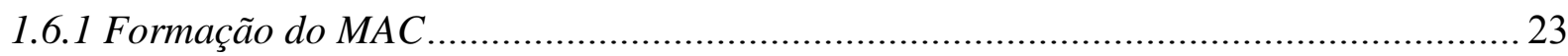

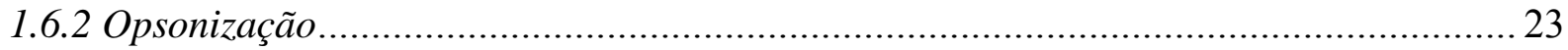

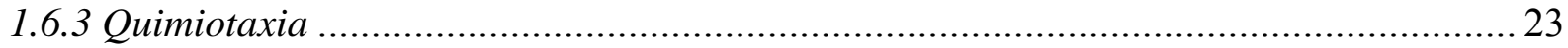

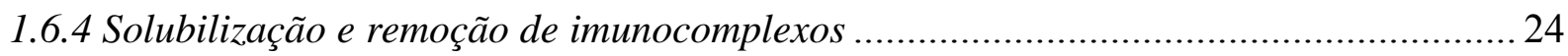

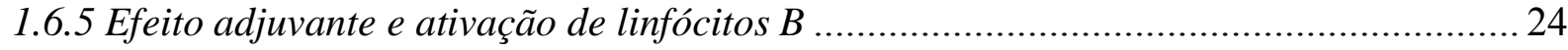

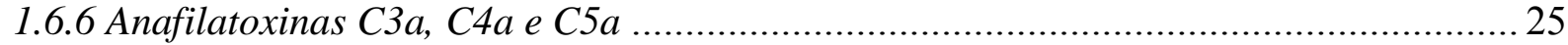

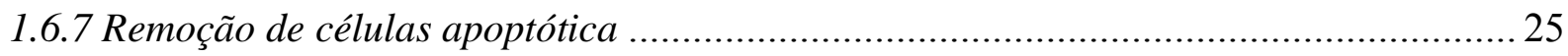

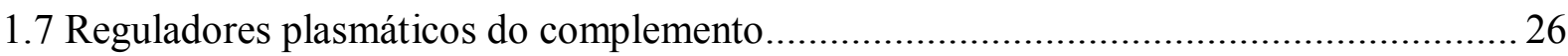

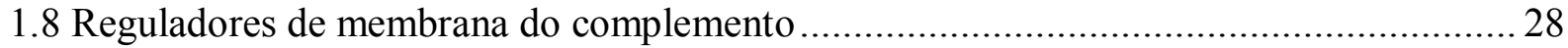

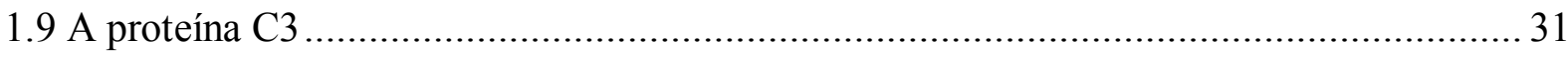

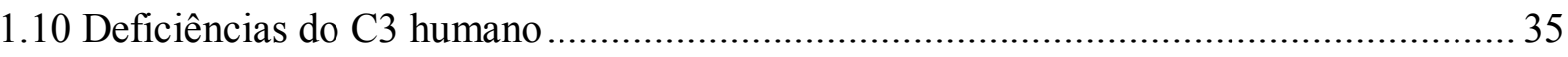

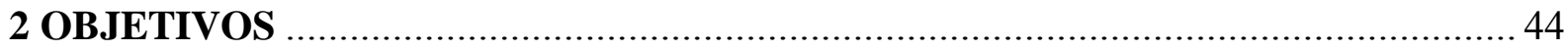

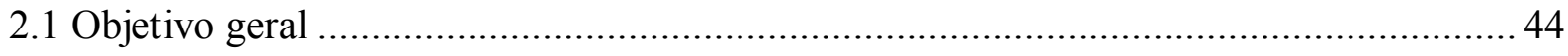

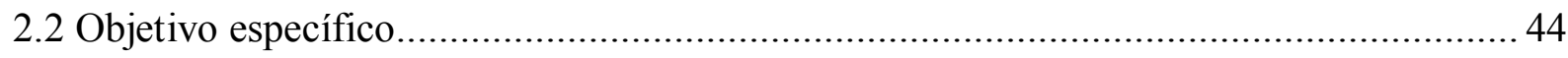

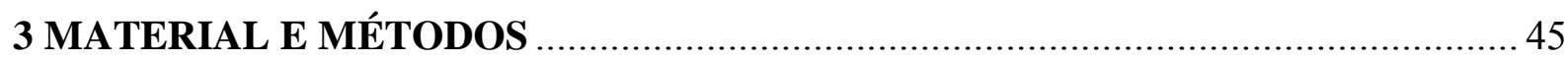

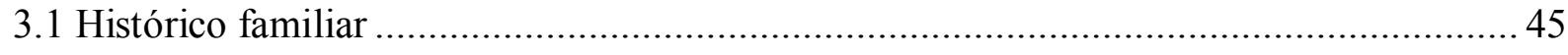

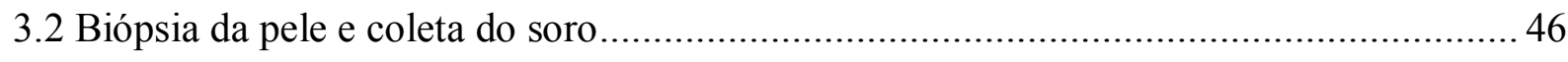

3.3 Determinação da concentração de proteínas por imunodifusão

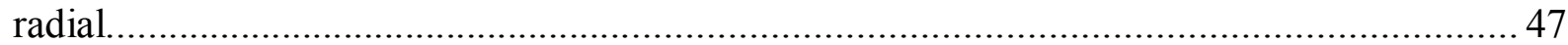

3.4 Atividade hemolítica mediada pela via alternativa do sistema complemento ....................4 47

3.5 Atividade hemolítica mediada pela via clássica do sistema complemento ........................ 48 
3.6 Cultura de fubroblastos e estímulo com LPS ............................................... 49

3.7 Extração de RNA de fibroblastos e estímulo com LPS ............................................. 50

3.8 Extração de DNA genômico de fibroblastos .............................................................. 50

3.9 Síntese de cDNA empregando transcriptase reversa e amplificação por reação em cadeia

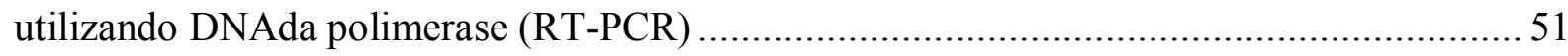

3.10 Purificaçãodos produtos da reação de RT-PCR ........................................................ 51

3.11 Sequenciamento do cDNA de C3 humano e DNA genômico do gene de C3 ............... 52

3.12 Concentração de sobrenadante de fibroblastos estimulado com LPS .......................... 55

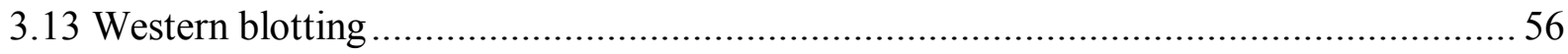

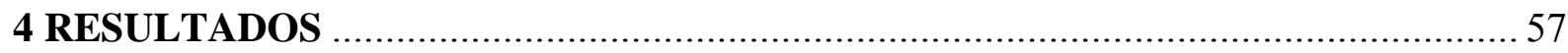

4.1 Análise da concentração de proteínas por imunodifusão radial .................................. 57

4.2 Análise da atividade hemolítica da via alternativa do sistema complemento ................. 58

4.3 Análise da atividade hemolítica da via clássica do sistema complemento..................... 59

4.4 Análise por Western blotting da presença de C3 nos soros da família e análise densitométrica 60

4.5 Análise do gel de agarose com regiões do cDNA de C3amplificadas por RT-PCR ........ 62

4.6 Análise do gel de agarose do fragmento $\mathrm{H}$ amplificadas por RT-PCR......................... 63

4.7 Análise do sequenciamento genético da região $\mathrm{H}$ do cDNA de $\mathrm{C} 3$ e do gene $C 3$........... 63

4.8 Análise por Western blotting da presença de C3 no sobrenadante em cultura de fibroblastos

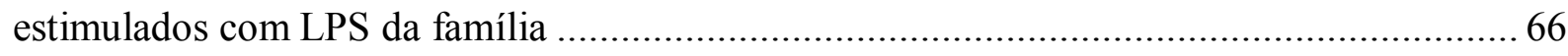

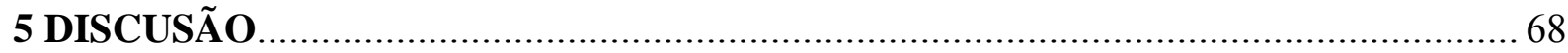

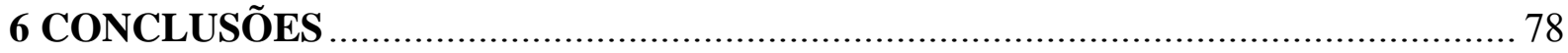

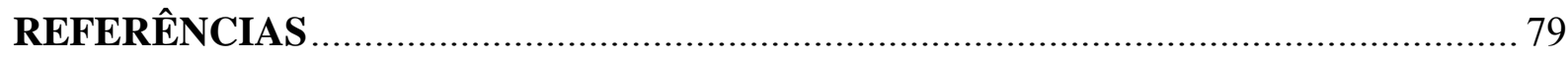




\section{INTRODUÇÃO}

\subsection{O Sistema Complemento}

O sistema complemento é importante para defesa contra patógenos e participa tanto da resposta imune inata, quanto da resposta imune adquirida. Pesquisas realizadas durante a última década mostram como o complemento discrimina tecidos saudáveis do hospedeiro, restos celulares, células apoptóticas, células neoplásicas e patógenos e ainda sincroniza uma resposta imunológica eficiente (Ricklin et al., 2010).

Composto por aproximadamente 40 proteínas, este sistema está presente tanto no plasma quanto na superfície de vários tipos celulares (Trouw et al., 2011). Estas proteínas interagem entre si e com outras moléculas do sistema imunológico de forma altamente regulada para a eliminação do microorganismo, geralmente sem causar danos ao indivíduo. O principal local de síntese da maioria das proteínas do complemento é o fígado, embora algumas proteínas como C3 possam ser sintetizadas localmente por macrófagos, células dendríticas e fibroblastos (Katz et al., 1989; Reis et al., 2006; Reis et al., 2007; Trouw et al., 2011; Walport, 2001). Suas principais funções biológicas envolvem o reconhecimento e eliminação de patógenos, remoção de imunocomplexos, além de servir como uma ponte entre a resposta imune inata e a resposta imune adaptativa. O sistema complemento quando ativado também promove reações inflamatórias pela geração das anafilatoxinas $\mathrm{C} 3 \mathrm{a}, \mathrm{C} 4 \mathrm{a}$ e C5a, além da ativação de células como leucócitos e células endoteliais (Ricklin et al., 2010).

Sua ativação depende de uma cascata proteolítica de serino proteases caracterizadas pela alta conservação dos sítios catalíticos de serina, histidina e aspartato (Amara et al., 2011). Esta ativação pode ocorrer por três vias distintas, a via clássica, a via alternativa, e a via das lectinas que culminam em uma via terminal comum que leva à formação do Complexo de Ataque à Membrana (MAC), responsável pela lise osmótica da célula alvo (Figura 1). 
Figura 1 - Representação das três vias de ativação do sistema do complemento e a formação do MAC

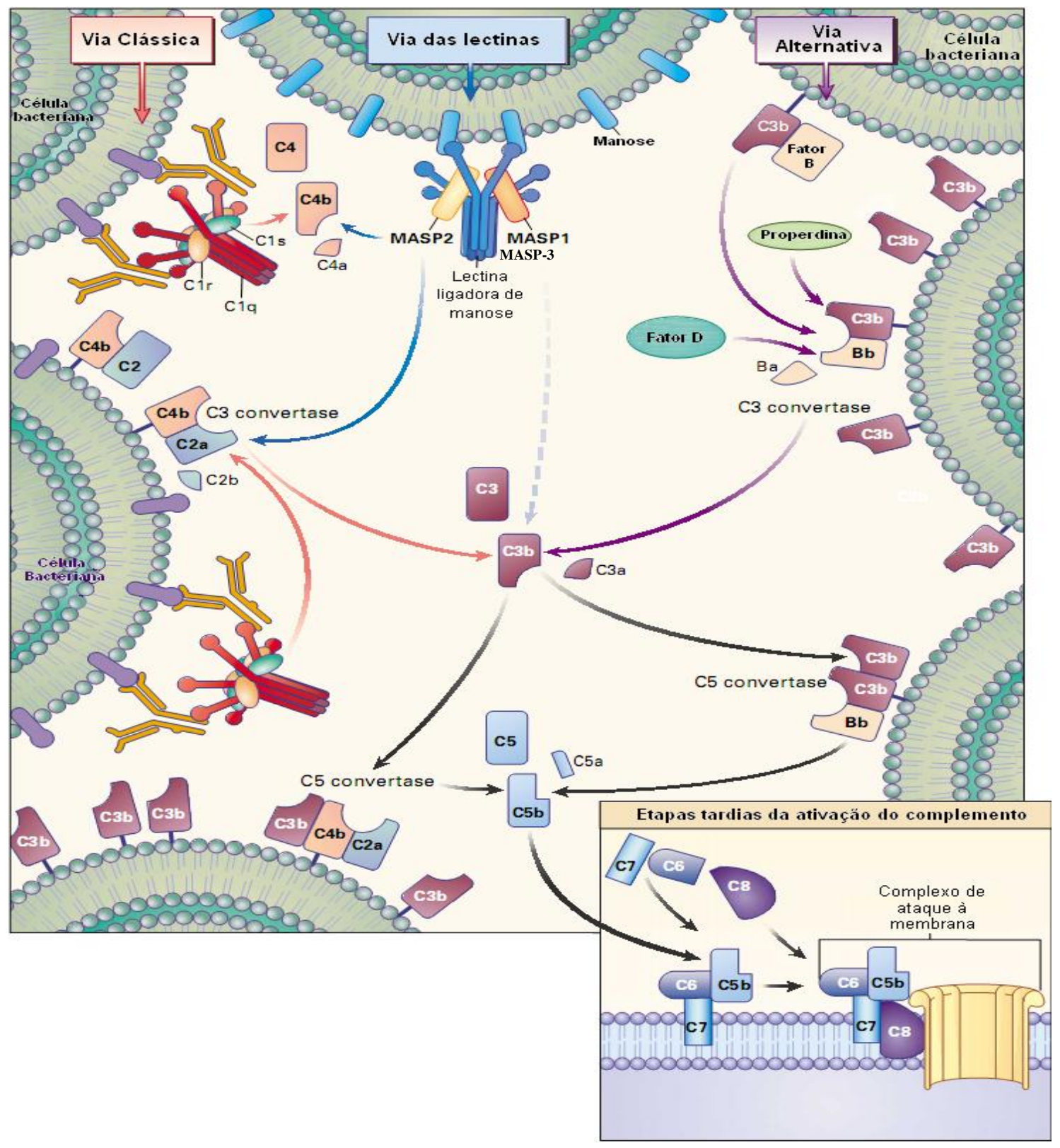

Vias de ativação do sistema complemento. A via clássica pode ser ativada por IgM e IgG específicas ligadas ao antígeno. A via das lectinas pode ser ativada pela ligação da mannose binding lectin (MBL) a resíduos de manose ou outros tipos de açúcares. MBL pode ser encontrada associada às serino proteases (MASP) 1, 2 e 3. A via alternativa é iniciada pela hidrólise espontânea da ligação tiól-éster encontrada na cadeia $\alpha$ do C3 nativo com formação de $\mathrm{C} 3$ convertase e geração dos fragmentos $\mathrm{C} 3 \mathrm{~b}$. As três vias culminam em uma via terminal comum que leva à formação do complexo de ataque à membraba (MAC) a partir da associação de $\mathrm{C} 5 \mathrm{~b}$ as proteínas $\mathrm{C} 6 \mathrm{e} \mathrm{C}$. $\mathrm{Na}$ sequência, $\mathrm{C} 8$ se liga a $\mathrm{C} 7$ e várias proteínas $\mathrm{C}$ 9 se ligam a $\mathrm{C}$.

Fonte: Adaptado de Walport, 2001. 


\subsection{A Via Clássica}

A via clássica foi historicamente a primeira a ser descrita e pode ser ativada de formas diferentes (Walport, 2001), mas principalmente na presença de imunocomplexos. Esta via pode ser iniciada pela interação de pelo menos uma molécula de $\operatorname{IgM}$ ou duas moléculas de $\operatorname{IgG}$ específicas ligadas à superfície do antígeno. Este imunocomplexo se liga à subunidade $\mathrm{C} 1 \mathrm{q}$ do complexo $\mathrm{C} 1$ pela porção $\mathrm{Fc}$, domínios $\mathrm{CH}_{2}(\operatorname{IgG})$ ou $\mathrm{CH}_{3}$ (IgM). $\mathrm{O}$ componente $\mathrm{C} 1$ é formado por uma molécula de C1q, e duas de C1r e C1s. A molécula de C1q é composta por 18 cadeias polipeptídicas ( 6 cadeias A, 6 cadeias B e 6 cadeias C). Já as moléculas C1r e C1s são proteases

formadas cada uma por uma cadeia única de $90 \mathrm{kDa}$ e $85 \mathrm{kDa}$, respectivamente. A molécula $\mathrm{Clq}$ apresenta um peso molecular de $400 \mathrm{kDa}$ (Campbell et al., 1979; Lacroix et al., 1989; Yonemasu et al., 1980) e, ao se ligar ao complexo antígeno-anticorpo se ativa e cliva a subunidade C1r, que por sua vez cliva a subunidade $\mathrm{C} 1 \mathrm{~s}$, ativando-a. Esta clivagem ativa $\mathrm{C} 1 \mathrm{~s}$ que irá clivar o componente $\mathrm{C} 4$ gerando os fragmentos $\mathrm{C} 4 \mathrm{a}$ e $\mathrm{C} 4 \mathrm{~b}$ (Figura 1). Após hidrólise da ligação tiól-éster em C4, há deposição covalente de C4b no local da sua ativação (Ricklin et al., 2010). O componente $\mathrm{C} 2$, uma vez ligado ao fragmento $\mathrm{C} 4 \mathrm{~b}$, será clivado por $\mathrm{C} 1 \mathrm{~s}$ dando origem aos fragmentos $\mathrm{C} 2 \mathrm{a}$ e $\mathrm{C} 2 \mathrm{~b}$ (Golan et al., 1982). O fragmento $\mathrm{C} 2 \mathrm{~b}$ é liberado, dando origem ao complexo $\mathrm{C} 4 \mathrm{~b} 2 \mathrm{a}$ que atua como uma $\mathrm{C} 3$-convertase que, por sua vez, irá clivar a proteína $\mathrm{C} 3 \mathrm{em}$ $\mathrm{C} 3 \mathrm{a}$ e C3b. O fragmento C3b poderá também se ligar à C4b2a formando C4b2a3b (C5convertase) a qual clivará a proteína C5, gerando os fragmentos C5a e C5b (Janssen et al., 2007; Zipfel, Skerka, 2009). O fragmento C5b irá se ligar a C6 formando o complexo C5b6 ao qual C7 se ligará (C5b67) que por sua vez irá se ligar a C8 e sequencialmente várias moléculas de C9, dando origem a uma via terminal comum com formação do complexo de ataque à membrana (C5b6789n) (MAC) (Figura 3) (Ricklin et al., 2010).

A proteína C-reativa pertence à família das pentraxinas e também pode ativar a via clássica do complemento, independente de anticorpos específicos (Kaplan, Volanakis, 1974). Em condições inflamatórias agudas ou injúria tecidual, a proteína C-reativa é encontrada no plasma em maior concentração ligando-se à molécula $\mathrm{C} 1 \mathrm{q}$, deslocando o $\mathrm{C} 1$-inibidor, desencadeando da mesma forma a cascata proteolítica da via clássica.

\subsection{A Via Alternativa}


A via alternativa, segunda via a ser descrita, é a mais antiga evolutivamente e a mais empregada na defesa contra patógenos. Sua ativação tem início a partir da hidrólise espontânea da ligação tiól-éster (Figura 2) localizada na cadeia $\alpha$ do $\mathrm{C} 3$, gerando $\mathrm{C} 3\left(\mathrm{H}_{2} \mathrm{O}\right)$ (Walport, 2001). Acompanhado por mudança conformacional, o $\mathrm{C} 3\left(\mathrm{H}_{2} \mathrm{O}\right)$ é capaz de se ligar à proteína plasmática Fator B (FB). O FB é uma pró-enzima com $93 \mathrm{kDa}$ que interage com a superfície do $\mathrm{C} 3\left(\mathrm{H}_{2} \mathrm{O}\right)$ formando o complexo $\mathrm{C} 3\left(\mathrm{H}_{2} \mathrm{O}\right) \mathrm{B}$. Nessa condição o FB é clivado por outra enzima, o Fator D (FD). O FD encontrado na forma ativa no plasma humano com peso molecular de $25 \mathrm{kDa}$ (Fearon et al., 1974; Pangburn et al., 1986). Quando o C3( $\left.\mathrm{H}_{2} \mathrm{O}\right) \mathrm{B}$ é clivado pelo FD, esta reação gera os fragmentos $\mathrm{Ba}$ e $\mathrm{Bb}$ (Figura 1). $\mathrm{O}$ fragmento $\mathrm{Bb}$ permanece ligado ao $\mathrm{C} 3\left(\mathrm{H}_{2} \mathrm{O}\right.$ ), formando a $\mathrm{C} 3$-convertase $\left[\mathrm{C} 3\left(\mathrm{H}_{2} \mathrm{O}\right) \mathrm{Bb}\right.$ ] a qual na presença de íons $\mathrm{Mg}^{++}$atua como serinoprotease, clivando $\mathrm{C} 3$ em $\mathrm{C} 3 \mathrm{a}$ e $\mathrm{C} 3 \mathrm{~b}$.

$\mathrm{O}$ fragmento $\mathrm{C} 3 \mathrm{~b}$ também pode interagir com $\mathrm{FB}$ formando $\mathrm{C} 3 \mathrm{bB}$. Uma vez complexado o FB agora poderá ser clivado igualmente por $\mathrm{FD}$ em $\mathrm{Bb}$ e Ba gerando $\mathrm{C} 3 \mathrm{bBb}$ que atua também como uma C3-convertase, clivando mais moléculas de $\mathrm{C} 3$, amplificando esta via de ativação. Como a C3-convertase é um complexo instável que pode ser rapidamente dissociado, sua estabilidade é assegurada pela properdina, que se liga à C3-convertase, estabilizando-a, regulando-a positivamente e aumentando a meia vida deste complexo (Fearon, Austen, 1975).

Figura 2 - Representação da ligação tiól-éster encontrada em C3 do sistema complemento

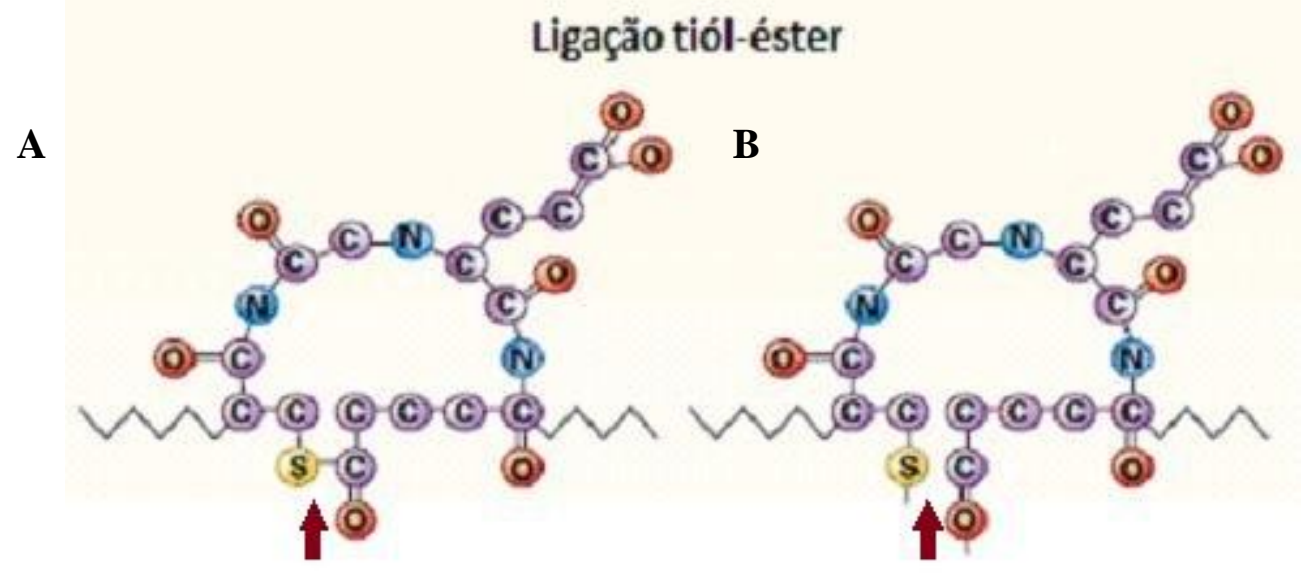

Em A: C3 intacto com ligação tiól-éster entre carbono e enxofre (seta) íntegra. Em B: C3 ativado, hidrólise da ligação tiól-éster entre carbono e enxôfre (seta) inicia a ativação da via alternativa do sistema complemento. Fonte: Adaptado de Walport, 2001. 
A hidrólise da ligação tiól-éster do componente C3 permite a ligação covalente de $\mathrm{C} 3\left(\mathrm{H}_{2} \mathrm{O}\right)$ e $\mathrm{C} 3 \mathrm{~b}$ em grupamentos amina ou hidroxila, na superfície da célula alvo ou de moléculas aceptoras. Esta ativação inicial pode ser rapidamente amplificada em células ou microorganismos estranhos, mas é imediatamente regulada no hospedeiro (Müller-Eberhard, Pangburn, 1980; Ricklin et al., 2010).

Quando $\mathrm{C} 3 \mathrm{~b}$ se liga à enzima $\mathrm{C} 3 \mathrm{bBb}$, forma o complexo $\mathrm{C} 3 \mathrm{bBb} 3 \mathrm{~b}$ que atua como $\mathrm{C} 5$ convertase, capaz de clivar o componente C5 gerando os fragmentos C5a e C5b. Como resultado, o fragmento C5b irá se ligar a C6 e C7, C7 se liga a C8 que se liga em séria sequencialmente a proteínas C9, formando assim C5b6789(n) (MAC) capaz de lisar o patógeno (Ricklin et al., 2011; Ware et al., 1981).

\subsection{A Via das Lectinas}

A via das lectinas é ativada em resposta ao reconhecimento da lectina ligante de manose (MBL) de polissacarídeos microbianos presentes em vários patógenos como bactérias, leveduras, protozoários e vírus. A MBL é uma proteína que pertence à família das colectinas com $650 \mathrm{kDa}$ com 18 subunidades de $31 \mathrm{kDa}$ e, na presença de íons $\mathrm{Ca}^{2+}$ é capaz de se ligar a Nacetilglicosamina, frutose e resíduos de manose de polissacarídeos (Ohta et al., 1990). A MBL possui uma estrutura semelhante à de C1q. Esta proteína está associada a serino-proteases MBLassociated serine protease (MASP)-1, MASP-2 e MASP-3. A MASP-1 é uma molécula com 83 $\mathrm{kDa}$ formada por uma cadeia pesada de $66 \mathrm{kDa}$ e uma cadeia leve de $31 \mathrm{kDa}$ responsável pela sua atividade proteolítica (Matsushita, Fujita, 1992). Já a MASP-2 possui uma massa molecular de 76 $\mathrm{kDa}$ e é formada por duas cadeias, a cadeia A com $52 \mathrm{kDa}$, e a cadeia B com $31 \mathrm{kDa}$ (Thiel et al., 1997). Em 2001, Dahl e sua equipe descreveram outro membro do complexo MBL, a MASP-3, assim designada devido à sua homologia estrutural com MASP-1 e MASP-2 (Dahl et al., 2001).

As MASP-1 e MASP-2 possuem estruturas e funções semelhantes àquelas encontradas em C1r e C1s. A MBL ao se ligar ao açúcar presente na parede celular do patógeno sofre uma mudança conformacional, e sua proteína associada MASP-2 é alterada estruturalmente tornandose ativa. A MASP-2 será responsável por clivar o componente $\mathrm{C} 4$ em C4a e C4b (Figura 1). O fragmento $\mathrm{C} 4 \mathrm{~b}$ irá se depositar covalentemente no local da sua ativação, seguido pela ligação de C2. Esta ligação permite que a MASP-2 também atue sobre a cadeia $\alpha$ polipeptídica única de C2 
clivando esta proteína em $\mathrm{C} 2 \mathrm{a}$ e $\mathrm{C} 2 \mathrm{~b}$. O fragmento $\mathrm{C} 2 \mathrm{a}$ permanece associado ao fragmento $\mathrm{C} 4 \mathrm{~b}$ originado dessa clivagem, formando $\mathrm{C} 4 \mathrm{~b} 2 \mathrm{a}$, que atua como uma $\mathrm{C} 3$-convertase clivando a cadeia $a$ de $\mathrm{C} 3$ em C3a e C3b. O fragmento $\mathrm{C} 3 \mathrm{~b}$ se liga à $\mathrm{C} 4 \mathrm{~b} 2 \mathrm{a}$ formando $\mathrm{C} 4 \mathrm{~b} 2 \mathrm{a} 3 \mathrm{~b}$, que por sua vez atua como uma C5-convertase clivando o componente C5 em C5a e C5b. Novamente o fragmento C5b irá se ligar a $\mathrm{C} 6$ e $\mathrm{C} 7, \mathrm{C} 7$ se liga a $\mathrm{C} 8$ que se liga sequencialmente a várias proteínas C9, formando assim o MAC (Mollnes et al., 2002).

Assim como MBL, as ficolinas também pertencem à família das colectinas, compartilhando com elas a presença de uma região estruturalmente semelhante ao colágeno e um domínio globular com afinidade a determinados carboidratos presentes em abundância em certos patógenos. Quando ocorre a ligação deste domínio globular ao patógeno, ocorre também a ativação da MASP-2 desencadeando uma atividade proteolítica contra os componentes $\mathrm{C} 2, \mathrm{C} 4 \mathrm{e}$ C3, iniciando a ativação da via das lectinas e a resposta imune contra o patógeno (Matsushita et al., 2000). Endo et al. (2012), utilizando camundongos nocaute para as ficolinas A e B (Fcna ${ }^{-/}$, $\mathrm{Fcnb}^{-/}$e $\mathrm{Fcna}^{-/} \mathrm{b}^{-/}$) mostraram sua importância na defesa contra infecção por Streptococcus pneumoniae. Quando a defesa do hospedeiro (camundongos) foi avaliada através da infecção transnasal com uma estirpe de Streptococcus pneumoniae capaz de ser reconhecida apenas pelas ficolinas $\mathrm{A}$ e $\mathrm{B}$ e não por $\mathrm{MBL}$, a taxa de sobrevivência bacteriana foi consideravelmente reduzida nos camundongos $\mathrm{Fcna}^{-/}, \mathrm{Fcnb}^{-/}$e $\mathrm{Fcna}^{-/} \mathrm{b}^{-/-}$em comparação aos animais controle. Isso mostra a incapacidade de ativação da via das lectinas na ausência dessas ficolinas, sugerindo que ambas são essenciais na infecção contra Streptococcus pneumoniae (Endo et al., 2012).

\subsection{MAC}

Todas as vias do sistema complemento culminam em uma via terminal comum e na formação do MAC. A C5-convertase gerada pelas vias clássica, alternativa e das lectinas, cliva a proteína C5 em C5a e C5b. Conforme já mencionado anteriormente, o componente C5 possui peso molecular de $190 \mathrm{kDa}$, e em muito se assemelha aos componentes C3, C4 e a2macroglobulina mas, ao contrário dessas proteínas, não apresenta ligação tiól-éster. O peptídeo C5a é um dos principais fatores quimiotáticos de células inflamatórias, participando ativamente do processo inflamatório (Aleshin et al., 2012; Bokisch et al., 1970). Já o fragmento C5b se associa a C6 (C5b6) ao qual C7 será acoplado. Em seguida a molécula de C8 será incorporada ao 
complexo formando C5b678. A ligação de C8 ao complexo C5b-7 aumenta drasticamente a interação hidrofóbica entre essas moléculas acentuando a ligação de várias unidades da proteína C9 (Aleshin et al., 2012; Ware et al., 1981). A glicoproteína C9 (71 kDa) possui alta afinidade pela membrana celular, facilitando sua inserção na bicamada lipídica.

Durante a associação de várias proteínas C9 (que pode ser de 12-18 moléculas de C9), ocorre a polimerização (poli-C9) fundamental para a formação do MAC (Figura 3). O MAC permitirá a entrada descontrolada de água, o extravasamento de material intracelular de baixo peso molecular e a saída de sais e íons que levam a célula ao desequilíbrio osmótico, ruptura da membrana celular e morte do patógeno (Ricklin et al., 2011; Ware et al., 1981).

Figura 3 - Formação do MAC.

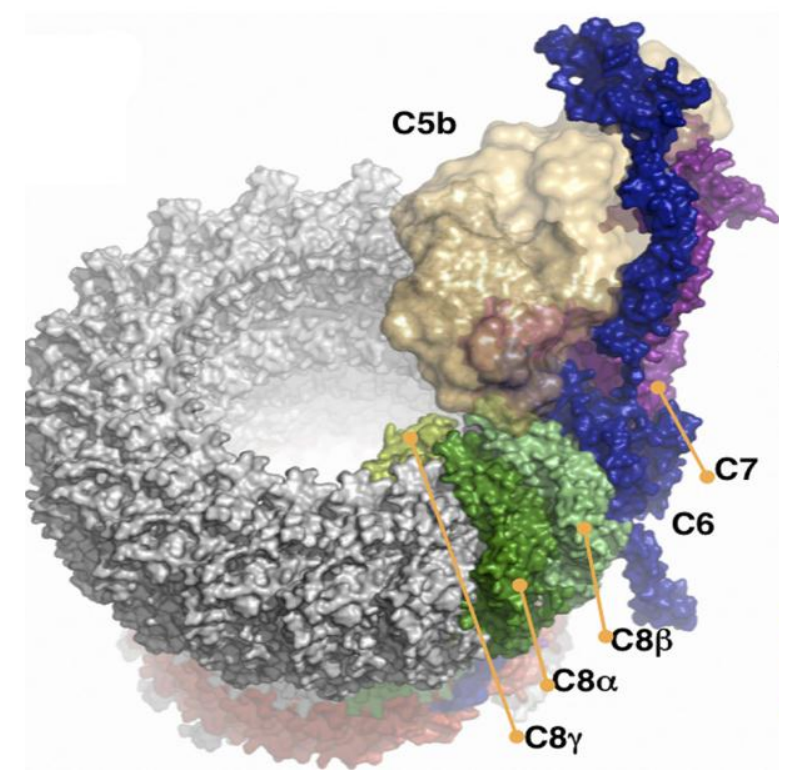

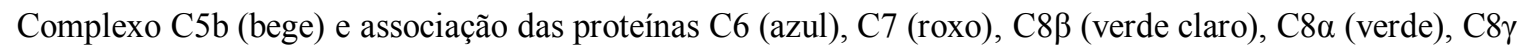
(verde musgo) e várias moléculas de C9 (cinza) que vão se inserir na membrana celular e após a polimerização dando origem ao MAC.

Fonte: Aleshin et al., 2012.

A perforina, encontrada em linfócitos $\mathrm{TCD}^{+}$e células natural killer $(\mathrm{NK})$, e a proteína C9 possuem muitas semelhanças tanto estruturalmente quanto funcionalmente. Ambas possuem um importante domínio altamente conservado que lhes permite a inserção na membrana celular, formando um canal responsável pelo seu papel lítico. Ambas também apresentam uma 
considerável homologia na sequência de aminoácidos (aa) dispostos na região N-terminal (Shinkai et al., 1988; Young et al., 1986).

1.6 Funções biológicas do complemento

\subsubsection{Formação do MAC}

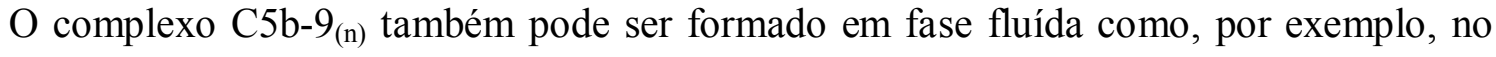
soro humano. Isso ocorre com a formação de um complexo C5b-9 hidrofílico que não exerce mais atividade lítica. Este complexo pode se associar à S-proteína que se liga de forma apolar a superfícies nascentes de moléculas C5b-7, alterando estruturalmente este complexo e o seu potencial de ligação à membrana celular permanecendo na fase fluída (Bhakdi et al., 1978). Muito se discute o papel do MAC na sua fase fluida, mas pouco se sabe até o momento.

\subsubsection{Opsonização}

A fagocitose é um importante mecanismo de remoção de células apoptóticas, necessário para a restauração da homeostase e resolução do processo inflamatório. Os fragmentos C3b, C4b

e iC3b participam ativamente desse processo facilitando a fagocitose. Esses fragmentos recobrem patógenos, produtos liberados durante lise celular e células apoptóticas, facilitando sua remoção pelos fagócitos via receptor CR1 (C3b e C4b), receptor CR2 (C3d e iC3b) e receptor CR3 e CR4 (iC3b) do complemento (Lambris et al., 1988).

Kemper et al. (2008) descreveram a função da properdina como opsonina, facilitando a fagocitose de células $\mathrm{T}$ apoptóticas. $\mathrm{O}$ complexo $\mathrm{C} 3 \mathrm{bBbP}$ pode se ligar a células $\mathrm{T}$ apoptóticas que expressam proteoglicanas específicas que irão mediar a opsonização pelos fagócitos via C3b do complexo.

\subsubsection{Quimiotaxia}

O fragmento do sistema complemento mais importante para o processo quimiotático é o C5a. Desde a década de 70, estudos mostram sua contribuição na quimiotaxia de polimorfonucleares durante o processo inflamatório para sua resolução (Snyderman et al., 1971). Este fragmento aumenta a síntese de moléculas de adesão por células endoteliais, a atração de leucócitos circulantes para o sítio inflamatório, aumentando a capacidade de eliminação do 
patógeno, além de aumentar a síntese e liberação de citocinas por diferentes tipos celulares (Manthey et al., 2009)

\subsubsection{Solubilização e remoção de imunocomplexos}

Imunocomplexos podem ser intercalados por $\mathrm{C} 3 \mathrm{~b}$ e $\mathrm{C} 4 \mathrm{~b}$ formando uma rede (Czop, Nussenzweig, 1976) e assim serem solubilizados evitando seu depósito em paredes vasculares e ativação do complemento que pode levar a reação inflamatória local. A remoção desses imunocomplexos pode ocorrer pelo receptor de complemento (CR) -1 do complemento, presente em eritrócitos e demais células sanguíneas. Os imunocomplexos recobertos por C3b e C4b se ligam ao CR1 e, ao passarem pelo fígado, são fagocitados pelas células de Kupffer (Cornacoff et al, 1983).

Helmy et al. (2005) mostraram a expressão do receptor CR1g (receptor pertencente à super-família das imunoglobulinas) nas células de Kupffer. Esse receptor se liga aos fragmentos $\mathrm{C} 3 \mathrm{~b}$ e iC3b do complemento aumentando sua eficiência no processo de fagocitose e, assim como CR1, removem os imunocomplexos da circulação.

\subsubsection{Efeito adjuvante e ativação de linfócitos $B$}

$\mathrm{O}$ efeito adjuvante do fragmento $\mathrm{C} 3 \mathrm{~d}$ do complemento foi explorado inicialmente por Dempsey et al. (1996). O estudo mostrou que a construção de um modelo de antígeno recombinante à base de lisozima de ovo de galinha ligado a uma, duas ou três moléculas de C3d imunogênica, estimulava a síntese específica de IgG1 logo após a primeira imunização.

Wang et al. (2004) construíram um antígeno recombinante utilizando a gonadotrofina corionica humana (hCG) e uma trinca de C3d (hCG $\beta$ ) como adjuvante. Seus resultados mostraram um aumento significativo nos níveis de anticorpos anti-hCG $\beta$ eficientes na neutralização da bioatividade da hCG.

Pepys et al. (1974) propuseram que o sistema complemento poderia estimular os linfócitos B para produção de anticorpos, e desde então, muitos autores investigaram essa função biológica. Bohnsack et al. (1988) estudaram os diferentes tipos de ligantes do CR2 para a

ativação dos linfócitos B. Carter et al. (1992) comprovaram que CD19 (uma proteína de membrana pertencente à superfamília das imunoglobulinas) presente nos linfócitos B, participa da sua ativação, sinalização e resposta imunológica. Dempsey et al. (1996) mostraram que os 
fragmentos C3d e C3dg ligados ao antígeno são capazes de estimular a síntese de anticorpos específicos por meio da ligação desses fragmentos ligados ao antígeno ao receptor receptor CR2 (CR2/CD19) presente nos linfócitos B concomitantemente a IgM de membrana específica. Camundongos foram imunizados com um modelo antigênico recombinante utilizando lisozima (de ovo de galinha) fundida com duas ou três cópias de C3d. Este antígeno foi de 1000 a 10000 vezes mais imunogênico do que a lisozima de ovo de galinha sozinha. No mesmo ano, Croix et al. (1996) estudando animais CR2 deficientes verificaram que a expressão desse receptor nos linfócitos B é fundamental para a resposta imunológica T-dependente.

\subsubsection{Anafilatoxinas C3a, C4a e C5a}

Os fragmentos C3a, C4a e C5a são conhecidos por sua atividade anafilática, isto é, sua capacidade de se ligar a mastócitos e basófilos (via receptor presente nessas células) desencadeando a liberação de mediadores pró-inflamatórios como heparina e histamina aumentando a síntese de moléculas de adesão pelas células endoteliais, recrutando leucócitos circulantes para o foco inflamatório (Manthey et al., 2009). C3a e C5a também podem estimular a produção de espécies reativas de oxigênio em neutrófilos aumentando sua ação microbiana (Elsner et al., 1994; Manthey et al., 2009).

Os fragmentos $\mathrm{C} 3 \mathrm{a}$ e $\mathrm{C} 3 \mathrm{a}_{\text {desARG }}$ (C3a que teve a arginina $\mathrm{C}$-terminal removida por carboxipeptidase N) podem agir aumentando a síntese e expressão de TNF- $\alpha$ e IL-1 $\beta$ em monócitos localizados em sítios inflamatórios, dessa forma modulando a resposta inflamatória (Takabayashi et al., 1996).

O fragmento C5a medeia a síntese e liberação de citocinas como IFN- $\gamma$ por diferentes tipos celulares além de participar do processo de reparação tecidual, promoção da angiogênese e produção de fatores de crescimento durante a resolução do processo inflamatório (Manthey et al., 2009; Mastellos et al., 2001).

\subsubsection{Remoção de células apoptóticas}

A remoção das células apoptóticas depende de C1q que se liga de à superfície das vesículas de células apoptóticas, impedindo a exposição de auto-antígenos para o sistema imune e 
prevenindo a formação de auto-anticorpos que podem desencadear o desenvolvimento de doenças auto-imunes (Korb et al.,1997). O reconhecimento molecular envolve as proteínas C1q e MBL da via clássica e lectinas respectivamente via receptor para $\mathrm{C} 1 \mathrm{q}$ (presente em células endoteliais e plaquetas). Essas proteínas têm uma ligação direta com a remoção de células apoptóticas e necróticas, facilitando sua opsonização pelas células dendríticas, e remoção do microambiente (Nauta et al, 2004).

Em 1996, Takizawa et al. (1996) mostraram que moléculas de iC3b se depositavam em células apoptóticas facilitando sua opsonização via CR3 e CR4. Mais tarde, Mevorach et al. (1998) mostraram que o bloqueio desses receptores reduzia significativamente a fagocitose de células apoptóticas recobertas por iC3b, comprovando sua importância na remoção dessas células.

\subsection{Reguladores plasmáticos do complemento}

O inibidor de $\mathrm{C} 1(\mathrm{C} 1 \mathrm{INH})$ é uma proteína que pertence a uma família de serino proteases envolvidas com o sistema de coagulação. Possui uma única cadeia conservada evolutivamente com 104 kDa composta por 370-390 aa e sua concentração no plasma é de aproximadamente 200 $\mu \mathrm{g} / \mathrm{mL}$ (Ziccardi, 1982).

O C1INH é capaz de inibir a ativação do complexo C1 (Ziccardi, 1982) bloqueando os sítios catalíticos de $\mathrm{C} 1 \mathrm{r}$ e $\mathrm{C} 1 \mathrm{~s}$, e que terminam por se dissociarem das moléculas de C1q, impedindo assim a ativação da via clássica do complemento (Figura 4) (Sim et al., 1979). Essa interação com C1 consiste em uma ligação irreversível em um sítio estrutural contendo de 30-40 aa na sua região carboxi terminal (Potempa et al., 1994). De forma semelhante, este regulador pode se associar às MASPs (MASP-1 e MASP-2), interrompendo a ativação da via das lectinas.

O Fator I (FI) pertence à família das serino proteases e sua concentração no plasma é $64 \pm 13 \mu \mathrm{g} / \mathrm{mL}$ (Ferreira de Paula et al., 2003). Esta proteína se apresenta na forma de um dímero com $88 \mathrm{kDa}$ contendo duas subunidades, uma cadeia pesada de $50 \mathrm{kDa}$ e uma cadeia leve de 38 $\mathrm{kDa}$. A cadeia leve do FI possui três sítios de glicosilação e uma região catalítica com aa importantes para o desempenho da sua função. A cadeia pesada de FI também possui três sítios de glicosilação e é composta por 32 aa (Catterall et al., 1987; Pangburn et al., 1977).

O FI é responsável pela clivagem da cadeia $\alpha$ tanto do $\mathrm{C} 3 \mathrm{~b}$ quanto do $\mathrm{C} 4 \mathrm{~b}$, porém é necessária a presença de co-fatores como Fator H (FH), proteína de membrana com atividade de 
cofator (MCP), CR1 ou a proteína ligante de C4b (C4BP) (Figura 4). Quando isso acontece, o $\mathrm{C} 3 \mathrm{~b}$ é clivado em iC3b e posteriormente nos fragmentos $\mathrm{C} 3 \mathrm{c}$ e $\mathrm{C} 3 \mathrm{dg}$; $\mathrm{C} 4 \mathrm{~b}$ é clivado em $\mathrm{C} 4 \mathrm{c}$ e C4dg, dessa forma interrompendo a formação da C3-convertase e a continuidade da cascata de ativação do complemento (Pangburn et al., 1977).

O FH é uma glicoproteína de cadeia única composta por 1231 aa com peso molecular de

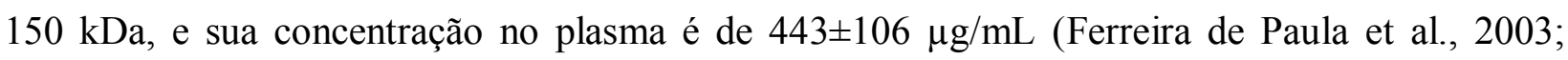
Ripoche et al., 1988; Whaley, Ruddy, 1976). O FH age sobre C3b promovendo o deslocamento de $\mathrm{Bb}$ acelerando o decaimento do complexo $\mathrm{C} 3 \mathrm{bBb}$, consequentemente regulando a via alternativa do complemento. Este componente também desempenha o papel de cofator favorecendo a clivagem do C3b pelo FI e o decaimento funcional da C3-convertase (Pangburn, 1986).

A C4BP é um importante cofator de FI com concentração plasmática de aproximadamente $335 \pm 83 \mu \mathrm{g} / \mathrm{mL}$ (Ferreira de Paula et al., 2003; Rezende et al., 2004; Scharfstein et al., 1978). Liga-se a C4b promovendo a dissociação e impedindo a formação do complexo C4b2a (C3convertase), acelerando seu decaimento e impossibilitando a continuação da cascata de ativação da via clássica, além de atuar como co-fator de FI (Fujita et al., 1978; Gigli et al., 1979; Scharfstein et al., 1978). Assim como outros reguladores do complemento, a C4BP compartilha com FH domínios comuns denominados short consensus repeat (SCR) formadas por aproximadamente 60-70 aa cada. C4BP pode ser encontrada em três isoformas compostas por diferentes subunidades originadas a partir de diferentes combinações entre as cadeias $\alpha$ e $\beta$. A forma mais comum é composta por sete cadeias $\alpha$ com oito SCRs cada, e uma cadeia $\beta$ com três SCRs (Sanchez-Corral et al., 1995).

A S-Proteína foi descrita por Podack e Müller (1979). Ela foi descoberta durante o estudo do complexo terminal C5b-9 na sua fase fluída, e somente em 1985, Janne e Stanley (1985) mostraram que a S-Proteína era idêntica à vitronectina, nome pelo qual esta proteína também é conhecida. A S-Proteína atua inibindo o local de interação entre os sítios de ligação de heparina e o complexo C5b-7, dessa forma, interrompendo sua interação com a membrana celular e a formação do MAC (Figura 3) (Milis et al., 1993). Seu peso molecular é de $75 \mathrm{kDa}$ e sua concentração no plasma em adultos normais varia entre 59,8 e 171,2 $\mu \mathrm{g} / \mathrm{mL}$ (Ferreira de Paula, 2002). 
A Proteína S-40,40 (Figura 5) foi identificada pela primeira vez em 1988, por Murphy et al. (1988) depositada no glomérulo renal em pacientes com gomérulonefrite. Hoje conhecida por clusterina, é uma proteína heterodimérica com $80 \mathrm{kDa}$ formada por duas cadeias (uma subunidade $\alpha$ e uma subunidade $\beta$ ) de $40 \mathrm{kDa}$ cada. Sua principal fonte são as células de Sertoli e sua concentração no plasma de indivíduos normais pode variar entre 35 a $105 \mu \mathrm{g} / \mathrm{mL}$. Semelhante à S-Proteína, este regulador se liga ao complexo C5b-7 impedindo sua interação com a membrana celular, a associação de C8-9 e formação do MAC (Fritz, 1992; Murphy et al., 1998).

A properdina é uma glicoproteína com $56 \mathrm{kDa}$ que pode formar dímeros, trímeros ou até tetrâmeros na sua forma ativa ou inativa. É o único regulador positivo do complemento e sua concentração no plasma é $25 \pm 5 \mu \mathrm{g} / \mathrm{ml}$ (Ferreira de Paula et al., 2003). Sua principal função é estabilizar o complexo C3bBb aumentando sua meia vida (Ferries et al., 1988).

A carboxipeptidase-N (CPN) foi descoberta em 1960, por Erdös e Slone (1960) como uma enzima plasmática capaz de inativar a bradicinina, após a remoção de resíduos de arginina C- terminal nela presentes. Anos mais tarde se descobriu que a CPN é um importante inativador de anafilatoxinas (Gerard, Hugli 1981). A CPN é uma enzima tetramérica com peso molecular de $280 \mathrm{kDa}$, formada por duas subunidades, uma com $48 \mathrm{kDa}$ que é responsável pela sua ação enzimática, e uma subunidade com $83 \mathrm{kDa}$ que promove a estabilização da molécula. Sua concentração no plasma é de aproximadamente $30 \mu \mathrm{g} / \mathrm{mL}$ (Bokisch et al., 1970; Levin et al., 1982). A CPN age em C3a, C4a e C5a da mesma forma que age na bradicinina, removendo a arginina presente na porção C-terminal dessas moléculas, interrompendo a ação anafilática e inflamatória dessas moléculas (Hugli, 1984).

\subsection{Reguladores de membrana do complemento}

O CR1 ou CD35 foi o primeiro receptor a ser descrito desempenhando um papel muito importante na regulação do complemento. O gene que codifica este receptor está localizado no cromossomo 1, na região q32 (banda 32 do braço longo do cromossomo). O CR1 atua como cofator de FI ao clivar os fragmentos $\mathrm{C} 3 \mathrm{~b}$ e $\mathrm{C} 4 \mathrm{~b}$. O iC3b gerado pode então ser novamente clivado pelo FI na presença de cofatores como FH, C4BP ou o próprio CR1 (que pode ser encontrado também na forma solúvel), dando origem aos fragmentos C3c e C3dg (Figura 4). O fragmento C3dg será então clivado por outras proteases gerando C3d e C3g (Weiss et al., 1989). 
Figura 4 - Clivagem e regulação da proteína C3 do complemento

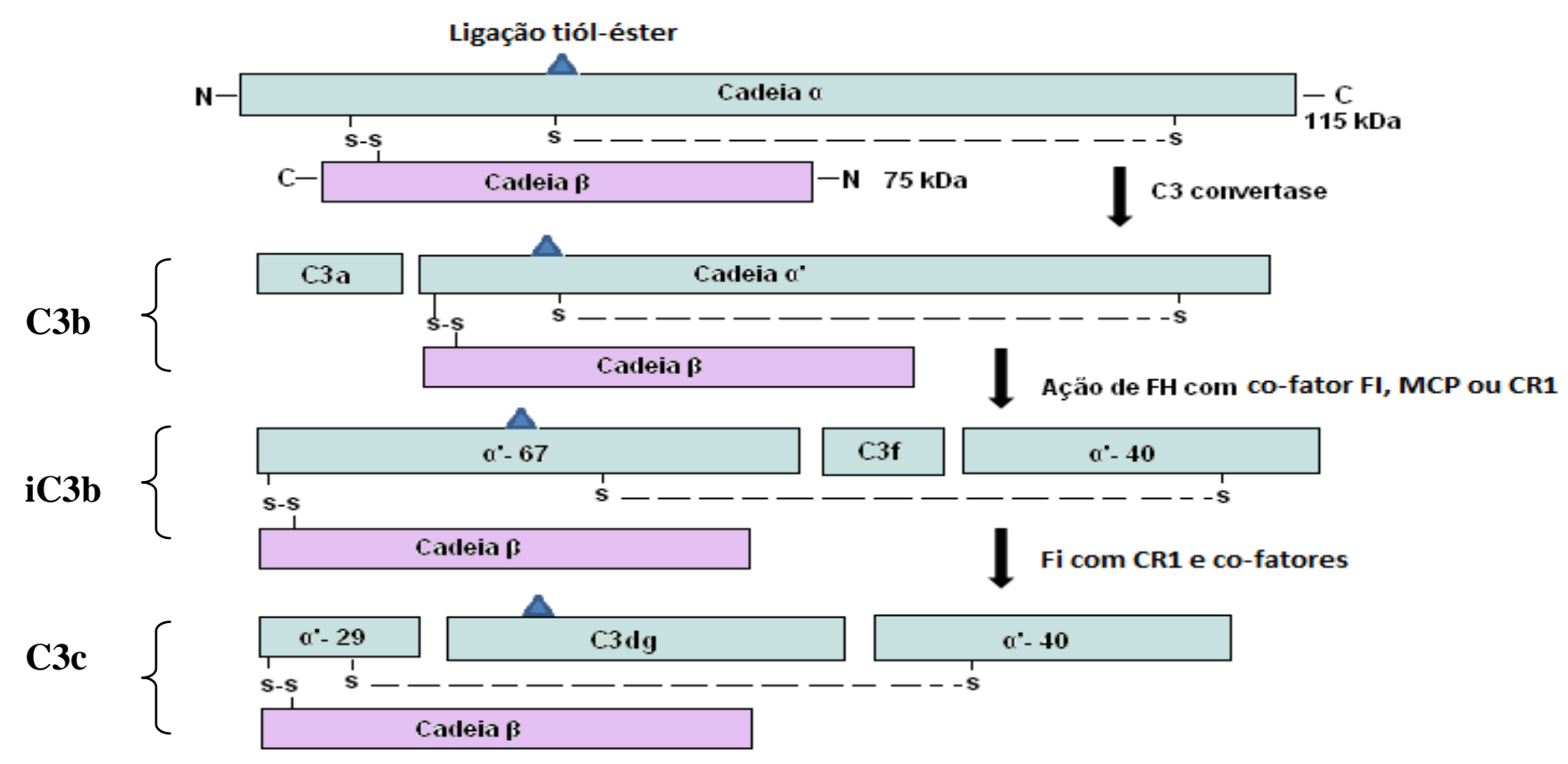

Degradação dos produtos da $\mathrm{C} 3$ convertase gerando C3a e C3b que é clivado por FI e cofatores que podem ser $\mathrm{FH}, \mathrm{MCP}$ e CR1. O C3b pode sofrer uma nova clivagem pelo FI na presença de co-fatores gerando iC3 e C3f. O fragmento iC3b pode sofrer uma clivagem pelo FI na presença de co-ftores dando origem a C3c e C3dg. C3c e C3dg irão sofrer ação de outras proteases que irão clivar esses fragmentos.

Fonte: Modificado de Agarwal et al., 2001.

O CR1 é uma glicoproteína de cadeia única com peso molecular de aproximadamente 220 $\mathrm{kDa}$ que pode ser encontrada ancorada na membrana celular por uma curta cauda citoplasmática, ou está presente na forma solúvel no plasma. Este receptor é encontrado em vários tipos celulares como eritrócitos, neutrófilos, eosinófilos, monócitos e macrófagos, células dendríticas, linfócitos T e B e células de Langerhans (Ahearn et al., 1989; Weiss et al., 1989).

A MCP ou CD46 (Figura 5) está presente em vários tipos celulares como fibroblastos, linfócitos T e B, células endoteliais, e em todos os demais leucócitos, exceto em eritrócitos. Esta proteína possui uma cadeia com 45-70 kDa, composta por uma cauda hidrofóbica transmembrana com 31 aa seguida de 14-23 aa citoplasmáticos, e uma porção N-terminal com sítios de glicosilação. A MCP atua como cofator de FI na clivagem de C3b e C4b inibindo a formação das convertases das três vias de ativação (Matsumoto et al., 1992; Seya et al., 1986). 
Figura 5 - Reguladores do complemento

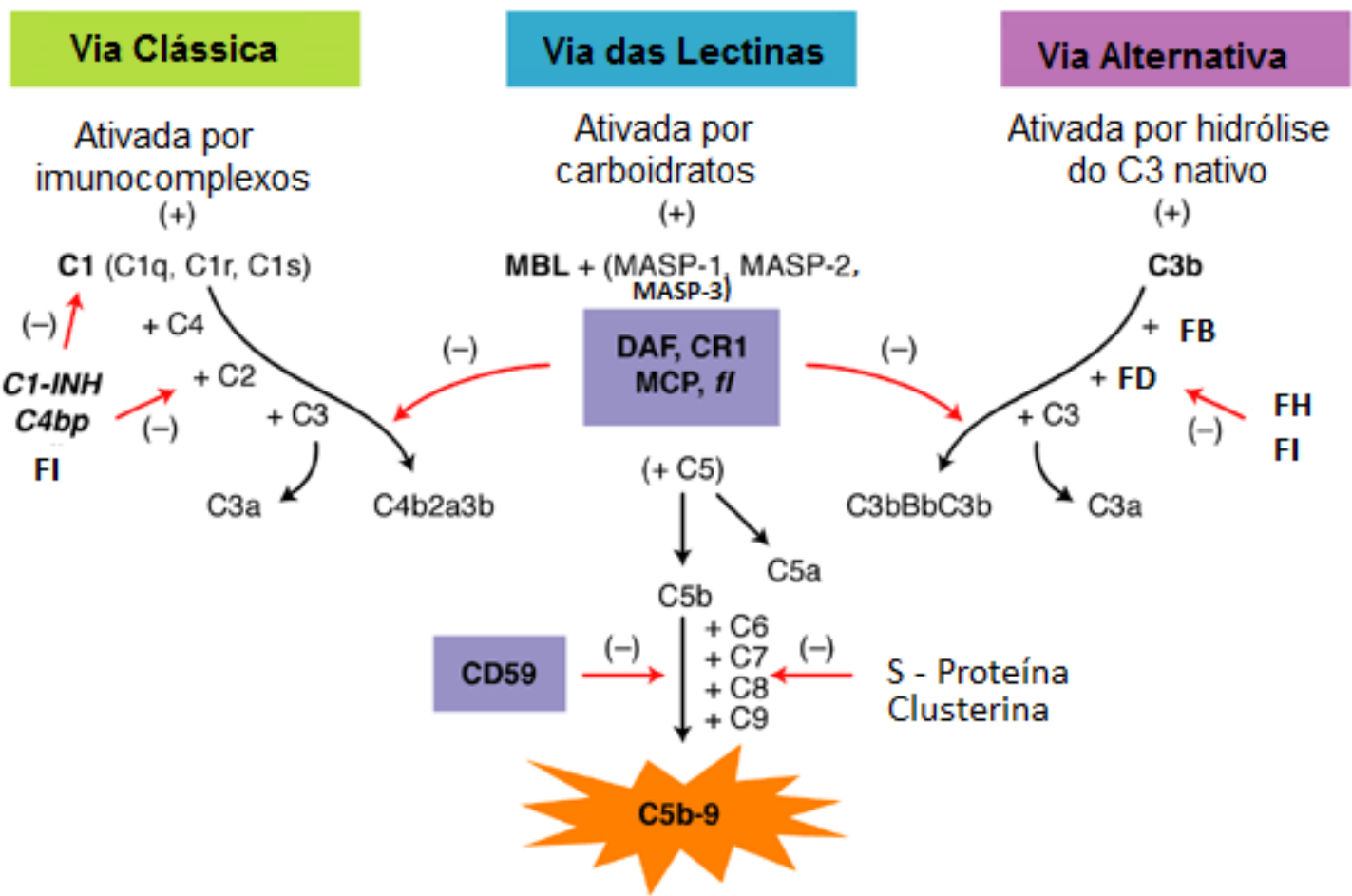

C1-INH: inibidor de C1. C4bp: proteína ligante de C4b. FI: Fator I. MBL: lectina ligante de manose. DAF: fator de aceleração de decaimento. CR1: receptor de complemento 1. MCP: proteína de membrana com atividade de co-fator. CD59: inibidor de lise de membrana. Clusterina e S-Proteína. FH: Fator H. Masp-1,2 33 (Mannose binding lectin-associated serine protease).

Fonte: Modificada de Francis et al., 2003.

A proteína Decay-accelerating factor (DAF) possui aproximadamente $70 \mathrm{kDa}$ e encontrase distribuída em vários tipos celulares como células epiteliais glomerulares, eritrócitos e leucócitos. A DAF está inserida na membrana celular por uma âncora de glicosil-fosfatidilinositol responsável por transmitir sinais intracelulares, mas também pode ser encontrada solúvel no plasma. Sua principal função é acelerar o decaimento da $\mathrm{C} 4 \mathrm{~b} 2 \mathrm{a}$ da via clássica ou $\mathrm{C} 3 \mathrm{bBb}$ da via alternativa da C3-convertase e C5-convertase, respectivamente (Figura 5), dissociando a ligação desses complexos (Lublin et al., 1989; Richard et al., 1989).

O homologous restriction factor (HRF) assim como a DAF está presente em vários tipos celulares e encontra-se inserido na membrana através da âncora de GPI. Esta proteína com 65 $\mathrm{kDa}$ possui alta afinidade pelos componentes C8 e C9 da via terminal comum e sua ligação ao complexo C5b-8 e C5b-9 impede a formação do MAC (Martin et al., 1987, Tandon et. al., 1992). 
A glicoproteína CD59 (Figura 5) é um importante regulador do sistema complemento e assim como as proteínas DAF e HRF está ancorada a membrana celular por GPI. O CD59 humano possui $20 \mathrm{kDa}$ e encontra-se amplamente distribuído em linfócitos, células epiteliais, endoteliais e sanguíneas. Sua ligação ao componente C8 ou C9 bloqueia a inserção dessas moléculas na bicamada lipídica, a polimerização e formação do MAC (Davis et al., 1989, Meri et al., 1990).

\subsection{A proteína C3}

O gene C3 humano está localizado no cromossomo 19 (Whitehead et al., 1982) que compreende $42 \mathrm{~kb}$ com 41 éxons e um peso molecular aproximado de $190 \mathrm{kDa}$. A proteína C3 que pertence à família da $\alpha 2$-macroglobulina tem aproximadamente 1663 aa que formam duas cadeias distintas $\alpha$ e $\beta$, ligadas por uma ponte de sulfeto (Figura 4) (Bruijn et al., 1984; Fong et al., 1990; Janssen et al., 2005).

A cadeia $\beta$ (Figuras 6 e 7) possui $75 \mathrm{kDa}$ abrangendo os 23-667 aa codificados pelos 16 primeiros éxons. Durante todo o processo de clivagem da proteína C3, esta cadeia se mantém íntegra sem sofrer clivagem proteolítica. Já a cadeia $\alpha$ (Figura 6) possui $115 \mathrm{kDa}$ que abrangem 672-1663 aa codificados pelos 25 éxons restantes. Nesta cadeia está localizada a ligação tiol-éster (Bruijn et al., 1984; Janssen et al., 2005).

A concentração desta proteína no plasma é aproximadamente 1,3 mg/mL (Vik et al., 1991) e sua principal fonte de síntese são os hepatócitos (Alper, Rosen, 1976). Porém, estudos mostraram que este componente pode ser sintetizado por vários tipos celulares como células endoteliais (Warren et al., 1987), monócitos (Whaley, 1980), macrófagos (Cole et al., 1980), fibroblastos, leucócitos polimorfonucleares, além de células dendríticas (Reis et al., 2006; Reis et al., 2007). 
Figura 6 - Modelo baseado na estrutura cristalográfica de C3 humano

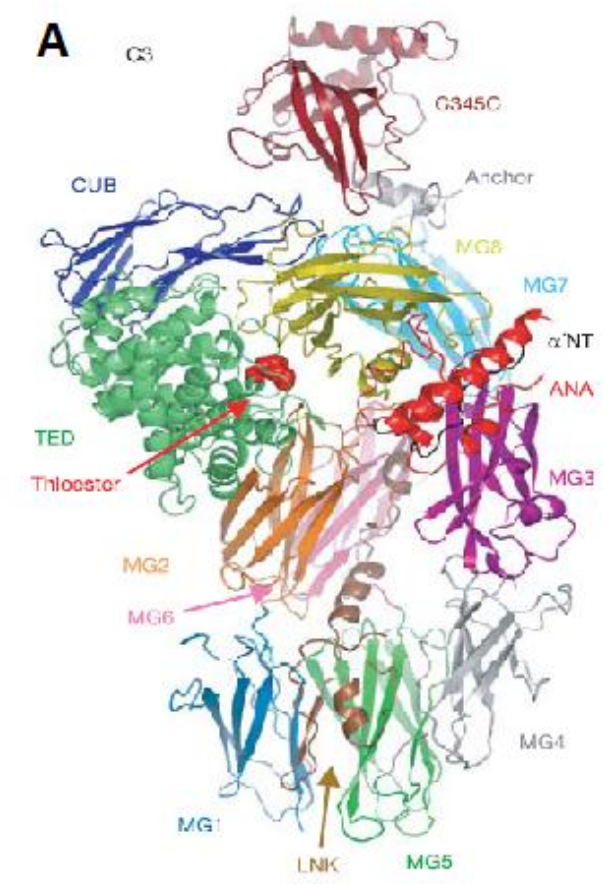

B

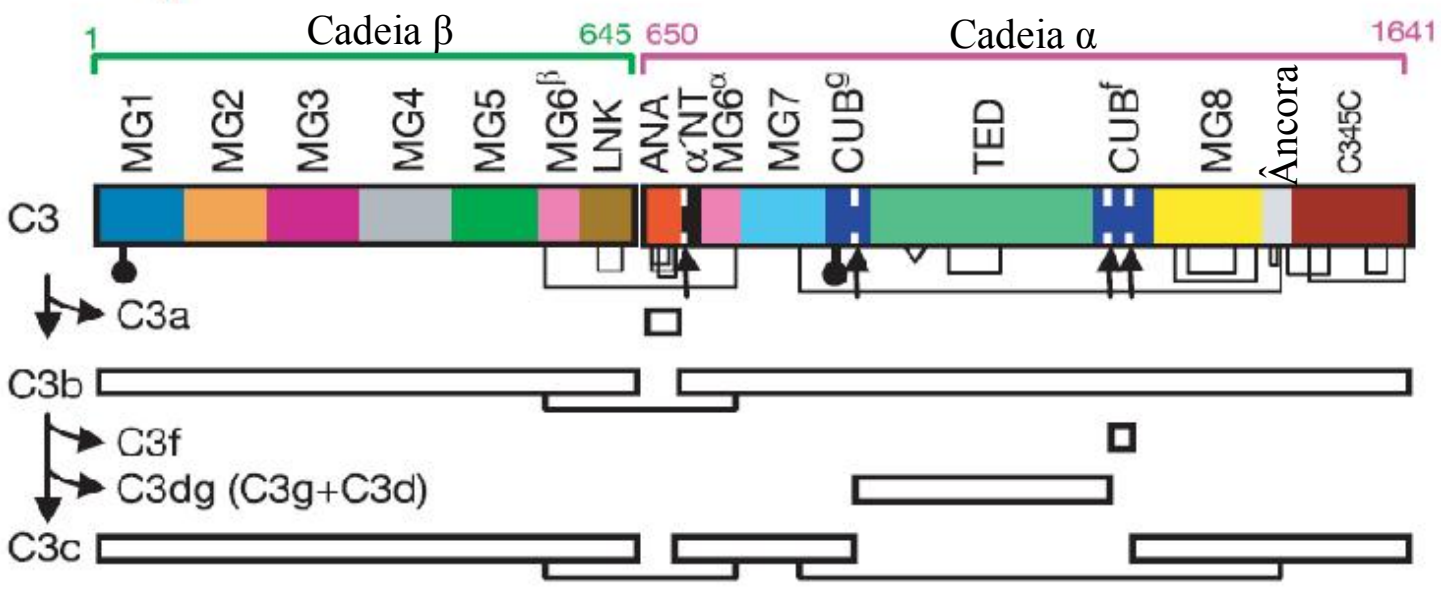

Em A temos a estrutura cristalográfica da proteína C3. Em B temos os domínios presentes na cadeia $\beta$ (1645), e na cadeia $\alpha$ (650-1641). Domínios do tipo macroglobulina de 1 a 8 (MG), domínio ligante (LNK), domínio anafilatoxina (ANA), sítio de clivagem da cadeia $\alpha\left(\alpha^{\prime} \mathrm{NT}\right)$, região dos domínios proteicos 912-962 (CUB ${ }^{\mathrm{g}}$ ) e domínios proteicos 1269-1330 (CUB ${ }^{\text {f) }}$, domínio tiól-éster (TED), domínio carboxi-terminal (C345C). Âncora. Clivagem do $\mathrm{C} 3$ gera C3a e C3b, e clivagem do C3b gera C3c, C3f, e $\mathrm{C} 3 \mathrm{dg}(\mathrm{C} 3 \mathrm{~g}+\mathrm{C} 3 \mathrm{~d})$.

Fonte: modificado de Janssen et al., 2005.

A clivagem do C3 ocorre entre os resíduos 77 e 78 (Arg-Ser) da cadeia $\alpha$ gerando os fragmentos $\mathrm{C} 3 \mathrm{~b}$ e $\mathrm{C} 3 \mathrm{a}$. Esse $\mathrm{C} 3 \mathrm{~b}$ gerado é capaz de se ligar covalentemente a hidroxilas ou 
aminas presentes na superfície de células, complexos carboidratos ou imunocomplexos. Esta ligação é fundamental para a continuada ativação do complemento e é mediada pela ligação tióléster envolvendo uma sulfidrila (Cys 988) e uma carboxila (Glu 990), ambas localizadas na região do C3d (Lambris, 1988). Diferente do C3 nativo, o C3b expressa vários sítios de ligação para várias proteínas do complemento que incluem properdina, FH, FI, FB, CR1 e MCP o que lhe permite a amplificação da ativação do complemento pela C3-convertase (via FB na presença de FD), ou a regulação através da inativação de C3b (via FI na presença de cofatores com MCP, CR1 e FH) (Lambris, 1988).

A regulação do fragmento $\mathrm{C} 3 \mathrm{~b}$ pelo FI é um processo que ocorre em três etapas e requer a presença de cofatores como MCP, CR1 e FH que irão induzir uma mudança conformacional permitindo que o FI possa interagir com C3b. Primeiro ocorre a clivagem da cadeia $\alpha$ entre os resíduos 1281-1282 (Arg-Ser). Em poucos segundos ocorre a clivagem entre os resíduos 12981299 (Arg-Ser) do C3 gerando os fragmentos iC3b e C3f. Em terceiro o FI medeia uma nova clivagem nos resíduos 932-933 (Arg-Glu) do iC3b gerando C3dg que posteriormente será clivado por outras proteases plasmáticas (Lambris, 1988).

Os eventos que levam à clivagem do $\mathrm{C} 3$ originam os fragmentos $\mathrm{C} 3 \mathrm{a}, \mathrm{C} 3 \mathrm{~b}, \mathrm{iC} 3 \mathrm{~b}, \mathrm{C} 3 \mathrm{c}$, C3dg e C3f (Figuras 4 e 6) que exercem várias propriedades biológicas. Os componentes C3b e iC3b participam do mecanismo de opsonização de antígenos, facilitando a internalização desses agentes pelos fagócitos (Walport, 2001). A desgranulação de mastócitos e basófilos é mediada pelo componente $\mathrm{C} 3 \mathrm{a}$, promovendo a liberação de mediadores inflamatórios como a histamina. $\mathrm{O}$ C3b também atua na solubilização e remoção de imunocomplexos formados na circulação. Este fragmento se liga de forma covalente aos imunocomplexos impedindo a formação de grandes complexos que, ao passarem pelo fígado, serão removidos da circulação sanguínea (Davies et al., 1994). O C3b também participa na formação da C5-convertase, via de ativação efetora contra o patógeno. Já o fragmento $\mathrm{C} 3 \mathrm{~d}$ atua na imunidade adquirida, estimulando a síntese de imunoglobulinas antígeno-específico pelas células B (Carroll, 1998; Ricklin et al., 2011).

Hartmann et al. (1997) mostraram que o fragmento C3a é capaz de estimular a quimiotaxia de mastócitos e a mobilização de cálcio livre, Daffern et al. (1995) provaram que C3a e C3adesArg são quimiotáticos para eosinófilos e ativador de neutrófilos, e Mousli et al. (1992) demostraram a eficiência desse fragmento C3a na estimulação da proteína $\mathrm{G}$ na ativação de mastócitos e liberação de histamina. 
Suresh et al. (2003) mostraram que animais C3 deficientes durante epsódio de infecção viral sistêmica causada por vírus da coriomeningite linfocítica tem o mecanismo de expansão de clones de linfócitos $\mathrm{TCD}^{+}$sigficativamente prejudicado diminuindo o número desssas células, mostrando sua necessidade do componente C3 na expansão dessas células efetoras.

Estudos cristalográficos de C3 descreveram minuciosamente cada domínio dessa proteína. O domínio thioester - containing domain (TED) na região 963-1268 aa que inclui os fragmentos C3d e C3g e o domínio CUB (912-962 aa e 1269-1330 aa) estão intimamente ligados (Figura 6). Esses domínios são altamente conservados e associados à proteção do hospedeiro contra o patógeno, compondo uma região nobre da proteína C3. O CUB se insere entre os domínios MG7 (807-911 aa) e MG8 (1331-1474 aa) gerando uma distância estrutural necessária para as interações moleculares e ligação com o domínio TED (Janssen et al., 2005).

A ligação tiól-éster é encontrada em um bolsão hidrofóbico localizado no domínio TED. Esse bolsão é formado por Cys 988 - Gln 991, resíduos altamente conservados entre certas proteínas do complemento e proteínas que pertencem à família $\alpha-2$ macroglobulinas, como é o caso do C3. A mudança conformacional do C3 nativo para que ocorra a hidrólise da ligação tióléster é impedida pelos domínios MG8-TED, bloqueando esta ligação e gerando um mecanismo de controle contra a hidrólise pela água. A posição do domínio TED é essencial para a manutenção e proteção do C3, o TED é sustentado pelas interações com MG2, MG8 e CUB responsáveis pela sua conformação estrutural essencial para ativação desse componente (Janssen et al., 2005).

Os resíduos 1-534 compreende os cinco domínios MG1 a MG5, além dos resíduos 535577 do domínio MG6 ${ }^{\beta}$ e LNK formando a cadeia $\beta$. Juntos os seis domínios MG1 a MG5 e MG6 ${ }^{\beta}$ formam voltas helicoidais como em um anel chave, e os resíduos 578-577 de MG6 formam um laço através desse anel e mais três hélices em uma configuração que se alinha ao domínio MG1 (Janssen et al., 2005).

O domínio ANA (650-726) se liga ao domínio MG6 por um extenso anel que abrange a região N-terminal (730-745). Os resíduos 746-806 formam $\mathrm{MG6}^{\alpha}$ (completando MG6) seguido de um sétimo domínio MG7 (807-911), e o domínio MG8 composto pelos resíduos 1331-1474 corresponde ao domínio $\alpha-2$ macroglobulina. Já os resíduos 1496-1641 formam a região carboxiterminal do domínio $\mathrm{C} 345 \mathrm{C}$ que está covalentemente ligado a MG8 por cadeias 
polipeptídicas e MG7 por uma ponte de sulfeto denominada como região Âncora (1475-1495) (Janssen et al., 2005).

A clivagem do $\mathrm{C} 3$ nativo remove o domínio anafilatoxina (ANA) gerando C3a e C3b, expondo a ligação tiól-éster antes oculta, mostrando o papel crítico que ANA tem na proteção indireta dessa ligação e a interação entre ANA e TED. ANA tem uma extensa interação com MG8 e MG3. Esta interação permite manter a estrutura proteica estável mantendo MG8 em uma posição correta, permitindo o aumento da interação com o domínio TED. As interações entre os domínios proteicos de C3 só são possíveis devido à conformação estrutural da molécula, e mudanças conformacionais que ocorrem durante sua ativação. Qualquer alteração estrutural em qualquer domínio pode ter sérias consequências, comprometendo a ativação e principalmente a função dessa proteína (Janssen et al., 2005).

\subsection{Deficiências do C3 humano}

A deficiência primária do $\mathrm{C} 3$ humano tem sido descrita em pacientes em diferentes regiões do mundo e até hoje 31 casos foram descritos. Suas manifestações clínicas consistem em infecções recorrentes por bactérias Gram-negativas como Neisseria meningitidis, Enterobacter aerogenes, Haemophilus influenzae, Escherichia coli, bactérias Gram-positivas como Streptococcus pneumoniae, otite média e, em alguns casos são acompanhadas por doenças mediadas por imunocomplexos (Reis et al., 2006).

Alper et al. (1972) descreveram pela primeira vez uma paciente africana com 15 anos de idade, suscetível a infecções piogênicas marcantes desde a infância. Esta paciente apresentou episódios de infecções por Streptococcus pneumoniae, Streptococcus pyogenes e Klebsiella pneumoniae, além de meningite e otite média. O estudo do caso mostrou que a paciente era homozigota para a deficiência de C3. Seus níveis séricos dessa proteína correspondiam a um milésimo abaixo do normal (Normal: 15-30 U/mL). Seus pais apresentaram níveis reduzidos de C3 (pai: $11 \mathrm{U} / \mathrm{mL}$, mãe: $7 \mathrm{U} / \mathrm{mL}$ ), quando comparados com pacientes normais. Posteriormente com os avanços da Biologia Molecular, Botto et al. (1992) demonstraram que esta diferença era causada pela deleção de 800 pares de base (pb) codificadores de parte da cadeia $\alpha$ do C3. Constatou-se a deleção dos éxons 22 e 23 e geração de um códon de parada prematuro no RNA 
mensageiro (RNAm) de C3 desta paciente (Alper et al., 1972; Botto et al., 1992) produzindo consequentemente uma proteína truncada.

Ballow et al. (1975) estudaram uma paciente com 4 anos de idade que, com um mês de vida apresentava diarréia persistente e otite média. Aos 17 meses e aos 23 meses de vida apresentou quadro febril associado à infecção por Streptococcus pneumoniae. Aos 20 meses sofreu novamente com quadro de diarreia, otite média e foi diagnosticada com infecção urinária causada por E. coli. A concentração de C3 sérica era $10 \%$ do normal e a análise da atividade microbicida bacteriana neste soro foi aproximadamente $11 \%$ e mesmo após a reconstituição do soro com C3 purificado foi 52\% (Ballow et al., 1975).

Grace et al. (1976) descreveram o caso de uma garota africana com 4 anos de idade que apresentou quadros constantes de meningite causada por pneumococos. A atividade hemolítica mediada pela via clássica (CH50) estava completamente ausente no soro, e o seu nível de C3 era zero. Seu irmão faleceu ainda na infância por meningite. Embora seus pais não possuíssem histórico de consanguinidade, ambos são heterozigotos para a deficiência da proteína C3 (Grace et al., 1976).

Um ano depois, Osofsky et al. (1997) estudaram o paciente S.A que sofreu com febre alta durante 5 dias, erupção máculopapular eritematosa, linfodenopatia, hepatoesplenomegalia, artralgias e otite média. A dosagem do nível sérico de C3 foi $<3 \mathrm{mg} / \mathrm{dL}$ (normal 80-180 mg/dL), e o ensaio hemolítico foi de $4 \mathrm{U} \mathrm{CH} 50 / \mathrm{mL}$ (normal $30 \pm 10 \mathrm{U} / \mathrm{mL}$ ). Enquanto o soro normal matava $100 \%$ de E. coli, o soro da paciente deficiente de $\mathrm{C} 3$ não apresentava essa propriedade. $\mathrm{O}$ paciente S.A tinha um irmão que faleceu, uma irmã normal e, outra irmã com metade do nível normal de C3, assim como outros membros da família testados (24 membros incluindo os pais). Os pais da paciente possuíam laços de consanguinidade (Osofsky et al., 1997).

Ainda em 1977, Davis et al. (1977) descreveram o caso de uma garota que aos 5 meses de idade desenvolveu episódios frequentes de infecção respiratória, febre alta e pneumonia. Com 1 ano de idade teve varicela, aos 3 anos sofreu otite média, convulsões, faringite, e aos 5 anos teve pneumonia. A primeira averiguação da atividade hemolítica mediada pela via clássica, feita na paciente em 1973, indicou $6 \mathrm{U} \mathrm{CH} 50 / \mathrm{mL}$ e, 2 anos mais tarde a atividade hemolítica foi $<1 \mathrm{U}$ CH50/mL (Normal: 32-45 U CH50/mL). A concentração de C3 no soro da paciente era $5 \mathrm{mg} / \mathrm{mL}$ enquanto um indivíduo normal apresentou 100-200 mg/mL (Davis et al., 1977). 
Três anos mais tarde, Pussel et al. (1980) relataram o caso de 3 irmãos de uma família com origem palestino-libanesa com homozigose para a deficiência de C3. Conforme heredrograma da família, o caso da paciente II-3, uma garota com 13 anos de idade, apresentou quadros frequentes de cefaléia, dor abdominal além de proteinúria. A irmã (II-5) com 7 anos de idade, sofria desde o primeiro ano de vida com proteinúria, hematúria e pneumonia. O irmão (II6), um garoto diagnosticado aos 5 anos de idade, aos 3 anos desenvolveu peritonite, proteinúria, e seus pais não possuíam laços de consanguinidade. A concentração de C3 no soro da mãe foi 89\%, e dos três irmãos foi zero, enquanto que o intervalo de normalidade é de $60-130 \%$ e a atividade hemolítica mediada pela via clássica foi $66 \%, 10 \%, 10 \%$ e $10 \%$ respectivamente, em relação ao soro referência (50-125\%) (Pussel et al., 1980).

O caso de uma garota chinesa de 10 anos de idade com completa ausência da proteína C3 foi publicado por Hsieh et al. (1981). Ela teve entrada no hospital com febre alta, tosse, artralgias e erupções cutâneas por uma semana. A paciente teve 12 episódios de pneumonia, 5 de otite média, bronquite e episódios de convulsões. A atividade hemolítica mediada pela via clássica do pai era $12,5 \%$, da mãe $30,0 \%$ e da paciente zero. A paciente tinha uma irmã mais velha que, aos 6 meses, teve pneumonia, meningite e posteriormente faleceu, e seus pais não possuíam histórico de consanguinidade (Hsieh et al., 1981). Mais tarde, em 1994, Huang et al. (1994) utilizando métodos de Biologia Molecular descobriram que esta paciente (na época com 22 anos de idade) apresentava no RNAm de C3 a exclusão de 34 nucleotídeos na região 3' do éxon 10 e substituição da base $\mathrm{G} \rightarrow \mathrm{T}$ no sítio doador de splice do íntron 10 do gene $C 3$, gerando um códon de parada prematuro responsável pela deficiência de C3 (Huang et al., 1994).

Ainda em 1981, foi descrito no Japão o caso de duas irmãs com lúpus eritematoso. A paciente 1 com 19 anos de idade sofria com episódios recorrentes de bronquite, erupções na face e artralgia contínua, embora gozasse de boa saúde até os 10 anos de idade. A paciente 2 com 14 anos de idade possuía um histórico médico semelhante ao da irmã. Os níveis de C3 no soro tanto da paciente 1 quanto da paciente 2 foram indetectáveis. O ensaio hemolítico feito com o soro da paciente 1 apresentou de $6,3 \mathrm{U} \mathrm{CH} 50 / \mathrm{mL}$, e a paciente 2 apresentou 5,8 U CH50/mL, e o SHN mostrou valor de $40 \mathrm{U}$ CH50/mL (Sano et al., 1981).

Roord et al. (1983) estudaram uma família holandesa, residente em um pequeno vilarejo. A família era composta pelo pai com 60 anos de idade, a mãe com 59 anos de idade, e mais 13 filhos com idades variadas. Dentre estes, um faleceu aos 3 anos com meningite, e outro com 6 
anos de idade sem histórico de infecções recorrentes. Conforme heredograma da família os pacientes dos casos II-6, II-10 e II-12 foram os objetos de estudo. A paciente do caso II-6, uma mulher com 26 anos de idade sofria com quadros de otite média constantes, e infecções cutâneas. Aos 5 anos contraiu Staphylococcus aureus, meningite e, aos 9 anos, teve sepse e meningite por Neisseria meningitidis. A paciente do caso II-10, uma garota com 19 anos de idade, desenvolveu meningite pneumocócica com 2 anos de idade e quadros constantes de otite média e posterior desenvolvimento de lesões cutâneas. Já a paciente do caso II-12, uma garota com 16 anos de idade apresentou quadro semelhante ao caso 10 sofrendo de otite média de repetição desde os 8 meses. A atividade hemolítica foi de $17 \mathrm{U} \mathrm{CH} 50 / \mathrm{mL}$ no caso $6,10 \mathrm{U} \mathrm{CH} 50 / \mathrm{mL}$ no caso 10 e 11 U CH50/mL no caso 12 (Normal: 185-261 U CH50/mL). A concentração de C3 funcional foi 232 $\mathrm{U} / \mathrm{mL}$ no caso $6,175 \mathrm{U} / \mathrm{mL}$ no caso 10 e $150 \mathrm{U} / \mathrm{mL}$ no caso 12 , indicando a homozigose para deficiência da proteína C3 entre os pacientes (Roord et al., 1983).

Neste mesmo ano, Berger et al. (1983) investigaram o caso de uma garota com 11 anos que, desde o primeiro mês de vida, apresentou quadros de infecções recorrentes e, aos 4 anos, foi diagnosticada com deficiência de C3. O nível desta proteína no soro da paciente não foi detectável por ensaios hemolíticos ou imunoquímicos. A biópsia renal mostrou proliferação endocapilar, difusão com aumento da matriz mesangial induzindo glomerunonefrite grave, alterações já descritas em outros casos de deficientes de C3 (Berger et al., 1983).

O caso de um garoto laociano com 7 anos de idade com deficiência da proteína C3 foi sucintamente descrito por Borzy e Houghton (1985). Além do baixo nível dessa proteína, o paciente apresentou episódios de infecções persistentes, hematúria, proteínúria, e a análise histopatológica renal mostrou sinais de mesangiopatia com glomerulonefrite transmembranar (Borzy, Houghton 1985).

Dois anos mais tarde em 1987, Cozma et al. (1987) relataram brevemente o caso de uma garota com 12 anos de idade com doença renal terminal e completa ausência da proteína C3. A paciente apresentou deterioramento gradativo do rim e posterior insuficiência renal. Uma biópsia deste órgão revelou $80 \%$ de esclerose glomerular com possível glomérulonefrite membranoproliferativa do tipo I (Cozma et al., 1987).

No Brasil, o primeiro caso de deficiência de C3 foi descrito por Grumach et al. (1988). O paciente C.A sofria desde os 3 meses de idade com infecções recorrentes por Giardia, broncopneumonia, meningite, otite média, febre alta, artrite e infecção urinária. A dosagem do 
C3 no soro da família foi $45 \mathrm{mg} / \mathrm{dL}$ para a mãe, $71 \mathrm{mg} / \mathrm{dL}$ para o pai e de zero para a paciente (Normal: 70-154 mg/dL). Dos indivíduos testados, 8 membros da mesma família apresentaram nível normal dessa proteína, embora outros 4 estavam no limite mínimo de normalidade (Grumach et al., 1988). Mais tarde no nosso laboratório investigou-se o RNAm de C3 desse paciente, quando se descobriu a presença de um códon de parada prematura no éxon 30 causada pela subtituição de um $\mathrm{G}$ por um $\mathrm{A}(\mathrm{G} \rightarrow \mathrm{A})$ na posição 1716 (Reis et al., 2002).

No mesmo ano, Borzy et al. (1988) estudaram o caso de um garoto de 10 anos de idade que, aos 5 meses, foi diagnosticado com infecção por Streptolococcus pneumoniae. Aos 7 meses foi internado com pneumonia lombar, aos 20 meses pela segunda vez teve infecção por $S$. pneumoniae que se repetiram aos 3 e aos 5 anos. Sua biópsia renal mostrou mesangiopatia e glomerulonefrite, mas ainda com função renal normal. Os níveis antigênicos de C3 no soro do paciente eram indetectáveis e no estudo da família apenas metade do nível desta proteína estava presente, quando comparado a um indivíduo normal (Borzy et al., 1988). Mais tarde, Singer et al. (1996) descreveram o caso desse paciente mais detalhadamente. Sua deficiência está associada ao baixo processamento, expressão e secreção de C3 pelas suas células. A expressão de RNA mensageiro de $\mathrm{C} 3$, tanto do paciente quanto dos seus parentes, foi muito baixa, quando comparadas com um indivíduo normal. Os dados sugeriram que o defeito genético esteja na mutação que afeta a transcrição do gene $C 3$, o processamento do RNA e sua estabilização, embora fosse necessário o aprofundamento do estudo molecular para sua confirmação (Singer et al., 1996).

Um ano mais tarde foi feito o breve relato do caso de uma mulher com 28 anos de idade com completa ausência da proteína C3 do complemento. Ela sofreu desde a infância com infecções de repetição, dentre elas pneumonia, meningite meningocócica e otite média. (Weiss et al., 1989).

Botto et al. (1990) descreveram o caso de um paciente com 10 anos que apresentou quadros recorrentes de otite média, infecções respiratórias e seus pais possuíam histórico de consanguinidade. A análise genética do paciente mostrou uma substituição GT $\rightarrow$ AT na região 5' no sítio doador de splicing do éxon 18 causando a deleção do éxon 8 e gerando um códon de parada prematuro no RNAm de C3 levando à deficiência dessa proteína (Botto et al., 1990).

Imai et al. (1991) descreveram o caso de um homem com 23 anos de idade que desde 1984 sofria de proteinúria persistente e microhematúria. Aos 4 anos, ele apresentou meningite e 
erupções cutâneas. Em sua família foram encontradas mulheres deficientes de C3 (homozigotas) portadoras de lúpus eritematoso sistêmico. A concentração de C3 foi $<1 \mathrm{mg} / \mathrm{dL},<9 \mathrm{U} \mathrm{CH} 50 / \mathrm{mL}$, a biópsia renal mostrou ligeira proliferação mesangial e glomerulonefrite, comum nos casos de pacientes homozigotos para a deficiência da proteína C3 (Imai et al., 1991).

Em 1992 foi relatado o caso de um neozelandês de 19 anos de idade que desde a infância apresentou episódios de febre alta, impetigo, pneumonia e meningococcemia. A proteína C3 não foi detectada no soro. A atividade hemolítica dependente da via clássica foi zero, enquanto o normal é $1600 \mathrm{U} \mathrm{CH50/mL}$ e, sua atividade hemolítica mediada pela via alternativa foi $20 \mathrm{U}$ AP50/mL contra 150 U AP50/mL do normal, confirmando sua deficiência (Peleg et al., 1992).

Ainda em 1992, Sanal et al. (1992) publicaram o caso de uma paciente com 4 anos de idade deficiente de C3. Seu histórico médico apresentou quadros de infecções piogênicas, otite média e meningites de repetição. Sua atividade hemolítica foi zero. Após a adição de C3 purificado no soro, a atividade hemolítica mediada pela via clássica subiu para 19,9 U CH50/mL enquanto no indivíduo controle foi 21,9 U CH50/mL (Sanal et al., 1992).

Outro paciente neozelandês com deficiência de C3 foi descrito por Singer et al. (1994). O estudo mostrou uma mutação no éxon 13 do cDNA do C3, alterando uma Asp para Asn em uma região importante e altamente conservada na cadeia $\beta$ do C3. No mesmo ano Katz e colaboradores publicaram um estudo em que eles identificaram nesse paciente o defeito na secreção da proteína C3. Ensaios de imunoprecipitação e de imunofluorescência utilizando fibroblastos mostraram a presença do pró-C3 intracelular, entretanto a proteína C3 não foi detectada no meio extracelular explicando sua deficiência (Singer et al., 1994). Um ano depois novamente Katz e colaboradores descreveram outro estudo feito com a família desse paciente. O pai apresentou uma concentração de C3 de $68 \mathrm{mg} / \mathrm{dL}$, a mãe $47 \mathrm{mg} / \mathrm{dL}$ e a irmã $165 \mathrm{mg} / \mathrm{dL}$ (normal $=130 \mathrm{mg} / \mathrm{dL}$ ). Já atividade hemolítica da via clássica foi de $976 \mathrm{U} \mathrm{CH50/mL} \mathrm{para} \mathrm{o} \mathrm{pai,}$ 925 U CH50/mL para a mãe e 1265 para a irmã (normal= 1370 U CH50/mL) (Katz et al., 1995).

Quatro anos mais tarde (2000), foi relatado o caso de duas irmãs japonesas por Matsuyama et al. (2000). A paciente 1 com 36 anos de idade, aos 16 desenvolveu sintomas de lúpus eritematoso sistêmico (SLE), mesma época do diagnóstico da deficiência de C3. A paciente 2 com 34 anos de idade foi diagnosticada com deficiência de C3 aos 14. A paciente 1 tinha o nível de C3 em $320 \mathrm{mg} / \mathrm{dL}$ e de 6,3 U CH50/mL. Já a paciente 2 tinha $270 \mathrm{mg} / \mathrm{dL}$ e 5,8 U CH50/mL (C3 Normal: 60-110 mg/dL e 40,0 U CH50/ mL). A análise molecular mostrou que as 
irmãs apresentavam a substituição da base $\mathrm{G} \rightarrow \mathrm{T}$ na posição 3303 do cDNA do $\mathrm{C} 3$, causando um códon de parada prematura no éxon 26 do gene $C 3$, resultando na deficiência de C3 (Matsuyama et al., 2000).

Mais tarde, em 2001 o nosso laboratório estudou o caso do paciente L.A.S então com oito anos de idade, histórico de consanguinidade e deficiente de C3 que sofria com adenites graves, sinusites, dois casos de tonsilites purulentas, broncopneumonia e infecção por Giardia lamblia. Sua dosagem de C3 foi $0,15 \mu \mathrm{g} / \mathrm{mL}$. Tanto a atividade hemolítica mediada pela via clássica quanto pela via alternativa de seu soro foi zero, e a expressão de RNAm de C3 era reduzida (Ulbrich et al., 2001). Mais tarde, Reis et al. (2002) estudando este paciente em nosso laboratório descreveram que sua deficiência era desencadeada por um códon de parada prematura na posição 848 no éxon 20 do RNAm de C3 responsável pelos baixos níveis de RNAm desta molécula (Reis et al., 2004).

Já em 2005, no Japão, foi descrito o caso de um homem com 22 anos de idade diagnosticado com lúpus eritematoso sistêmico. Seu histórico mostrou infecções de repetição por pneumonia, febre alta e eritema. Seu nível de C3 não era detectado no soro e seus pais possuíam histórico de consanguinidade. A análise da sequência genética apontou uma mutação no sítio receptor de splice $(\mathrm{AG} \rightarrow \mathrm{GG})$ no íntron 39 com uma alteração de 38 nucleotídeos, levando à deleção do éxon 39 do gene $C 3$. Utilizando fibroblastos do paciente foi possível verificar a presença do pró-C3 intracelularmente, porém a proteína madura não foi detectada no meio extracelular (Tsukamoto et al., 2005).

Bhide (2006) relatou brevemente o caso de uma família deficiente da proteína C3 do complemento. A paciente 1, uma garota com 3 anos de idade sofria com cefaléia, febre, vômitos, otite média e episódios de infecção por Staphylococcus pneumoniae e Escherichia coli. Seu irmão, o paciente 2 com 10 anos de idade que apresentava histórico médico semelhante ao da irmã. A dosagem da atividade hemolítica mediada pela via clássica do paciente 1 foi de apenas $28,5 \%$ e, da paciente 2 de 33,7 \%, contra 80-100\% do normal e, seu nível de C3 foi de 0,06 g/L para ambas as crianças (Normal: 0.7-1,6 g/L) (Bhide, 2006).

Três anos mais tarde, em 2008, Kida et al. (2008) descreveram o caso de um paciente japonês heterozigoto para o gene $C 3$ com 22 anos de idade que desde os 2 anos apresentava infecções bacterianas recorrentes, meningites, bronquites e pneumonia. A concentração de C3 não era detectado no soro, apresentando $<12 \mathrm{U} / \mathrm{mL}$ de $\mathrm{CH} 50$ contra 35-45 U/mL do normal. A 
inserção de um T na posição 3176 do éxon 24 e uma mutação não senso C3303G no éxon 26 resultaram em um códon de parada prematura responsáveis pela deficiência (Kida et al., 2008).

Singh et al. (2009) publicaram o estudo de uma garota que foi internada aos cinco anos de idade com febre alta, dor de cabeça, e sinais de meningite que foram confirmados após investigação médica. Porém a garota sofria desde o nascimento com histórico de infecções de repetição e novo quadro de meningite aos 3 meses. A concentração de C3 era $112 \mathrm{mg} / \mathrm{dL}$ bem abaixo de um indivíduo normal (770-1950 mg/dL). As causas da deficiência ainda não foram descobertas.

O caso de uma garota com 13 anos de idade deficiente da proteína C3 foi relatado em 2010. Em 1973 com cinco anos de idade a paciente desenvolveu caxumba, e três meses mais tarde edema generalizado com glomérulonefrite. Sua concentração de C3 no soro era muito baixa e a análise genética identificou uma mutação no exon 29 do gene de C3. A mutação consiste na deleção de dois nucleotídeos (TT) na posição c.3736_3737 causando um stop códon na posição 1246 alterando TT por fenilalanina causando a deficiência da proteína C3 do complemento (Rodriguez-Marco et al., 2010).

Recentemente no Japão, estudos relataram o caso de um garoto com 4 anos de idade que apresentou dois episódios de infecções com bactéria Estreptococcus pneumoniae, otite média aguda e gastroenterocolite. Seu nível de C3 era $0,3 \mathrm{mg} / \mathrm{dL}$ contra $75-150 \mathrm{mg} / \mathrm{dL}$ do normal e seus pais não tinha histórico de consanguinidade. O estudo genético apontou uma mutação não senso na região $1432 \mathrm{C}>\mathrm{T}$ (Arg 478 terminal) no éxon 12 do gene $C 3$ como causa da sua deficiência (Okura et al., 2011).

A deficiência de C3, como em alguns casos supracitados, é geralmente acompanhada pelo acúmulo de imunocomplexos. Quando a síntese desta proteína é reduzida ou até mesmo completamente ausente, isto pode contribuir para a deposição desses imunocomplexos em tecidos e órgãos causando lesões teciduais ou até mesmo falência do órgão em questão (Chen et al., 2010).

Pacientes deficientes da proteína C3 apresentam um quadro muito comum de infecções frequentes predominantemente bacterianas ou virais. Dos 31 casos aqui relatados, 14 apresentaram otite média, 8 apresentaram pneumonia, 10 apresentaram meningite e 6 relataram febre alta. Em alguns casos foi feito o diagnóstico da infecção caracterizada por Streptococcus 
pneumoniae, Streptococcus pyogenes, Klebsiella aerogenes, Escherichia coli e Giardia (Kida et al. 2008; Okura et al., 2011; Reis et al., 2006; Rodriguez-Marco et al., 2010; Singh et al., 2009 ).

Outros casos de pacientes deficientes de C3 apresentaram quadro de proteinúria, hematúria, faringite, lesões cutâneas, artrite e infecções respiratórias de repetição como bronquites e sinusite. Em apenas um caso houve de uma paciente que apresentou quadro de sepse por Neisseria meningitidis.

A deficiência da proteína C3 é rara na população mundial, com apenas 31 casos qui descritos desde 1972. Ao contrário de várias outras doenças genéticas, as mutações encontradas são exclusivas de cada caso. Observamos que em sua maioria são causados por alterações de nucleotídeos em uma posição específica, ou a deleção de um éxon gerando um códon de parada prematura causando a deficiência de C3, mas somente alguns casos tiveram suas bases moleculares definidas. Por essa razão e devido ao índice de pacientes deficientes de C3 com infecções constantes, é necessário o estudo aprofundado das causas moleculares desta deficiência e sua melhor compreensão para futuras terapias como alternativa de tratamento, e dessa forma promover uma melhor qualidade de vida para esses pacientes. 


\section{OBJETIVOS}

\subsection{Objetivo geral}

O objetivo principal desse trabalho é caracterizar a deficiência primária de $\mathrm{C} 3$ e suas bases moleculares na paciente objeto de estudo.

\subsection{Objetivos específicos}

Determinar os níveis de C3 e outras proteínas do sistema complemento no soro da família objeto de estudo e caracterizar a atividade hemolítica desse soro mediada pelas vias clássica e alternativa do complemento.

Caracterizar o padrão de herança desta deficiência na família objeto de estudo.

Determinar a capacidade de secreção de C3 em sobrenadante de cultura de fibroblastos da paciente e controle, estimulados por LPS. 


\section{MATERIAIS E MÉTODOS}

\subsection{Histórico familiar}

A família em estudo é natural da cidade de São Paulo. A paciente A.S.S nasceu em 24 de janeiro de 2006 e foi encaminhada para investigação desta deficiência pela Dra Anete Servciovic Grumack da Faculdade de Medicina do ABC. De acordo com o histórico médico, a paciente sofre de repetidas infecções graves desde o nascimento. Com sete dias de vida, ela apresentou febre alta seguida de convulsões que levaram ao seu internamento em Unidade de Terapia Intensiva. Durante sua internação ela desenvolveu um quadro de hidrocefalia que foi tratada, obtendo alta 17 dias depois. Com 1 ano de idade, a paciente foi novamente internada em UTI por celulite periorbital e, após alta, apresentou quadro de repetidas infecções das vias aéreas superiores. Com 2 anos de idade, a paciente sofreu nova internação por celulite cervival e infecção aguda das vias aérias superiores (IVAS). Com 3 anos de idade, sofreu nova internação por pneumonia causada por S. pneumoniae.

Para investigar a possibilidade de deficiência de complemento ou deficiência de imunoglobulinas, pesquisou-se as concentrações das proteínas C3 e C4, e de IgA, IgG e IgM, foram determinadas no soro da paciente, conforme Tabela 1.

Tabela 1 - Quantificação das concentrações séricas de C3, C4 e imunoglobulinas

\begin{tabular}{cccccc}
\hline & \multicolumn{2}{c}{ Proteínas $(\mathbf{m g} / \mathbf{m L})$} & \multicolumn{3}{c}{ Igs $\mathbf{( m g / m L )}$} \\
\hline Paciente & $\mathbf{C 3}$ & $\mathbf{C 4}$ & IgA & IgG & IgM \\
2 anos & $<0,10$ & 0,15 & $<0,41$ & 5,29 & 1,35 \\
3 anos & $<0,04$ & 0,18 & 0,30 & 9,18 & 1,60 \\
Valores normais* & 0,90 a 1,80 & 0,10 a 0,40 & Não & Não & Não \\
& & & informado & informado & informado \\
\hline
\end{tabular}

Dados fornecidos pela Dra Anete Sevciovic Grumack da Faculdade de Medicina do ABC.

*De acordo com os valores de referência adotados pelo Laboratório de Imunologia Humana do Instituto de Ciências e Biomédicas da Univercidade de São Paulo do Dr Antonio Condino Neto IgA: 3 meses - 3,9 anos = 0,04 - 1,76 mg/mL; IgG: 3 meses - 17,9 meses = 2,969,36 mg/mL; IgM: 3 meses $-11,9$ meses $/$ Feminino $=0,3-0,91 \mathrm{mg} / \mathrm{mL}$.

A porcentagem de leucócitos presente no sangue da paciente foi determinada, conforme ilustrada na Tabela 2. 
Tabela 2 - Contagem diferencial de leucócitos sanguíneos

\begin{tabular}{|c|c|c|c|c|}
\hline Tipos celulares & Paciente (\%) & $\begin{array}{c}\text { Paciente } \\
\text { (nocels/mL) }\end{array}$ & $\begin{array}{c}\text { Valores normais } \\
\text { (\%) }\end{array}$ & $\begin{array}{c}\text { Valores normais } \\
\text { (no-cels/mL) }\end{array}$ \\
\hline Leucócitos totais & Não informado & 12.960 & Não informado & $4.000-10.000$ \\
\hline $\begin{array}{c}\text { Neutrófilos } \\
\text { bastonetes }\end{array}$ & Não informado & Não informado & $3 \pm 2$ & $50-5.000$ \\
\hline $\begin{array}{c}\text { Neutrófilos } \\
\text { segmentados }\end{array}$ & 44 & 5.663 & $56 \pm 10$ & $2.300-6.600$ \\
\hline Linfócitos & 45 & 5.897 & $30 \pm 10$ & $1.000-4.000$ \\
\hline Monócitos & 6 & 726 & $6 \pm 4$ & $100-1.000$ \\
\hline Eosinófilos & 4 & 492 & $3 \pm 2$ & $50-500$ \\
\hline Basófilos & 1 & 168 & $<1$ & $25-80$ \\
\hline
\end{tabular}

Dados fornecidos pela Dra Anete Sevciovic Grumack da Faculdade de Medicina do ABC.

3.2 Biópsia da pele e coleta do soro

Após consentimento livre e esclarecido, este estudo foi iniciado seguindo as normas da Comissão de Ética em Pesquisa Envolvendo Seres Humanos (CEPSH) do Instituto de Ciências e Biomédicas da Universidade de São Paulo. Foi feita uma biópsia da pele da paciente, do controle e dos familiares, conforme descrito em Vyse e colaboradores (1996). As culturas foram mantidas em estufa de $\mathrm{CO}_{2}(5 \%)$ a $37{ }^{\circ} \mathrm{C}$, em meio de cultura Dulbecco's modified Eagle's medium (DEMEM) (Life Technologies, São Paulo, SP, Brasil), enriquecido com 10\% de soro fetal bovino (Life Technologies) previamente inativado por $1 \mathrm{~h}$ a $56^{\circ} \mathrm{C}$ (SFBi), e $1 \%$ de glutamina. A cultura foi mantida primeiramente em garrafas de $25 \mathrm{~cm}^{2}$ e $75 \mathrm{~cm}^{2}$ e, após proliferação, as células foram posteriormente congeladas em dimetilsulfóxido a 10\% contendo SFBi $90 \%$ e estocadas em nitrogênio líquido. Quando necessário, as células foram descongeladas e mantidas em cultura.

O sangue foi coletado, mantido em gelo por 60 min e centrifugado a $2000 \mathrm{x} g$ por $15 \mathrm{~min}$ a $4{ }^{\circ} \mathrm{C}$. Depois desse processo o soro foi coletado, dividido em alíquotas que foram imediatamente armazenadas em congelador a $-80^{\circ} \mathrm{C}$ até o momento do uso. 
3.3 Determinação da concentração de proteínas por imunodifusão radial

Para quantificar as proteínas C3, C4, FH, FI e FB do sistema complemento nos soros desta família, utilizamos o método de imunodifusão radial simples (Mancini et al., 1965). Uma placa de vidro de $8 \times 8 \mathrm{~cm}$ foi previamente revestida com $2 \mathrm{~mL}$ de agarose a $1 \%$ em água destilada, e secas em estufa a $37^{\circ} \mathrm{C}$. Posteriormente, esta placa foi recoberta com $6 \mathrm{~mL}$ de agarose (1\% em PBS) contendo anticorpos policlonais específicos para cada proteína (Complement Technology, Tyler, Texas, USA) diluídos a 2\%. Uma vez solidificada esta segunda camada de agarose, foram feitos poços de $3 \mathrm{~mm}$ de diâmetro onde foram adicionados (duplicatas) $5 \mu \mathrm{L}$ de soro da paciente, cada membro da família e controle. A placa foi incubada por $48 \mathrm{~h}$ no caso de C3, C4 e FI, e por 24 h para FB e FH em câmara úmida a $4{ }^{\circ} \mathrm{C}$, para difusão das amostras e formação do halo de precipitação. Após o período de incubação, as placas foram lavadas com solução fisiológica $(\mathrm{NaCl} 150 \mathrm{mM})$ por $24 \mathrm{~h} \mathrm{a} 4{ }^{\circ} \mathrm{C}$. Depois de secas, as placas foram coradas com azul de Coomassie por 20 min, e o excesso descorado por $2 \mathrm{~h}$.

Para a construção da curva padrão, incluímos uma mistura de soros humanos de 50 indivíduos normais, com concentrações das proteínas do complemento determinadas previamente. Para essa curva, adotamos as seguintes diluições para o soro: 100\%, 50\%, 25\% e 12,5\%. As diluições foram representadas como "x", e o diâmetro do halo formado em "y" em mm². Sendo assim, construímos uma curva de regressão linear do tipo $\mathrm{y}=\mathrm{a} \mathrm{x}+\mathrm{b}$, para obtermos $\mathrm{a}$ concentração das proteínas de interesse. Somente consideramos os valores, quando $\mathrm{R}^{2} \geq 0,95$. A determinação da concentração proteica foi feita em duplicata.

3.4 Atividade hemolítica mediada pela via alternativa do sistema complemento

Para o ensaio hemolítico da via alternativa do complemento, utilizamos $3 \mathrm{~mL}$ de uma suspensão de hemácias de coelho (1:2) em Alsever estéril (Bioboavista, Valinhos, SP, Brasil) completando para $15 \mathrm{~mL}$ com solução tampão AP-CTD (AP-CTD: VBS ${ }^{-}$[NaCl 20,95 g; Na Barbital 0,5 g; ácido barbitúrico 1,15 g; $\mathrm{pH}=7,2$ ]; EGTA 0,2 M; $\mathrm{MgCl}_{2}$ 0,2 M). Lavamos a suspensão de hemácias 3 vezes após centrifugação a 2500 x g a $4{ }^{\circ} \mathrm{C}$ por 15 min. Após descartar o sobrenadante, coletamos $100 \mu \mathrm{L}$ da papa de células ressuspendendo-a em 9,9 mL de AP-CTD. 
As hemácias diluídas $(100 \mu \mathrm{L})$ foram distribuídas em tubos contendo as diluições 1:4, 1:8, 1:10, 1:16 e 1:32 dos soros da família, da paciente e do controle. Em seguida, incubamos a reação em banho-maria por $30 \mathrm{~min}$ a $37^{\circ} \mathrm{C}$. Passado este período adicionamos $900 \mu \mathrm{L}$ de tampão $\mathrm{VBS}^{--}$ EDTA (VBS - 5x; EDTA 0,2 M) para interromper a ativação, seguido por centrifugação a $2500 \mathrm{x}$ $g$ por 10 min a $4{ }^{\circ} \mathrm{C}$ (Nilsson, Nilsson 1984). Como controle, incubamos as hemácias apenas com a solução VBS $^{-}$EDTA $(0 \%)$; com $\mathrm{H}_{2} 0$ para obtermos a lise total de hemácias $(100 \%)$. Para cada amostra removemos $350 \mu \mathrm{L}$ (em duplicata) do sobrenadante e transferimos para uma nova placa, a qual foi lida no leitor Espectramax Plus 384 (Molecular Devices, Sunnyvale, Califórnia, USA) a $405 \mathrm{~nm}$. Os valores encontrados em cada soro foram comparados com o esperado para lisar $100 \%$ de hemácias descontando-se o controle negativo (branco). A porcentagem de lise foi medida como segue:

$$
\begin{gathered}
\% \text { de lise }=\frac{\text { D.O amostra }- \text { D.O branco }}{\text { D.O } 100 \% 100} \text { Lise }- \text { D.O branco }
\end{gathered}
$$

Com este cálculo e preparo da curva, obtivemos o volume de soro necessário para lisar $50 \%$ de eritrócito, este volume corresponde a uma unidade AP50. O ensaio da atividade hemolítica da via alternativa foi feita em duplicata.

3.5 Atividade hemolítica mediada pela via clássica do sistema complemento

Para esta determinação, utilizamos $7 \mathrm{~mL}$ de suspensão de hemácias de carneiro em Alsever estéril 1:2 BBV (Bioboavista), e completamos para $15 \mathrm{~mL}$ com solução tampão $\mathrm{VBS}^{--}$ (VBS ${ }^{--} ; \mathrm{MgCl}_{2}$ 0,2 mM; $\mathrm{CaCl}_{2} 50 \mathrm{mM}$ ). Lavamos as hemácias 3 vezes por centrifugação a 2500 $\mathrm{x} g$ a $4{ }^{\circ} \mathrm{C}$ por $15 \mathrm{~min}$. Após descartar o sobrenadante, adicionamos $7 \mathrm{~mL}$ de $\mathrm{VBS}^{++}\left(\mathrm{VBS}^{-}\right.$; $\mathrm{MgCl}_{2}$ 0,2 mM; $\mathrm{CaCl}_{2} 50 \mathrm{mM}$ ) e $70 \mu \mathrm{L}$ de hemolisina (soro de coelho anti-hemácias) 1:100. Após incubarmos a reação em banho-maria por 30 min a $37{ }^{\circ} \mathrm{C}$, lavamos 1 vez por centrifugação a $2500 \times \mathrm{g}$ por $10 \mathrm{~min}$ a $4{ }^{\circ} \mathrm{C}$. Em seguida, descartamos o sobrenadante e completamos para o 
volume inicial com $\mathrm{VBS}^{++}$, homogeneizamos e retiramos $100 \mu \mathrm{L}$ de hemácias onde foram adicionados 4,9 $\mathrm{mL}$ de $\mathrm{H}_{2} \mathrm{O}$ Milli-Q estéril. Após esta etapa, diluímos as hemácias em tampão VBS $^{++} 1: 160$, e distribuímos $1,1 \mathrm{~mL}$ em tubos contendo as diluições $1 \mu \mathrm{L}, 1,25 \mu \mathrm{L}, 1,5 \mu \mathrm{L}, 1,75$ $\mu \mathrm{L}$ e 2,0 $\mu \mathrm{L}$ de soro da família, da paciente e do controle. Incubamos os tubos em banho-maria por 30 min a $37{ }^{\circ} \mathrm{C}$, seguido de centrifugação a 2500 x g por 10 min a $4{ }^{\circ} \mathrm{C}$ (Nilsson, Nilsson 1984). Como controle, incubamos as hemácias com a solução VBS- ${ }^{-}$EDTA (0\%) ou com $\mathrm{H}_{2} 0$ para obtermos a lise total de hemácias (100\%). Para cada amostra, $350 \mu \mathrm{L}$ (em duplicata) do sobrenadante foram removidos e transferidos para uma nova placa, a qual foi lida no leitor Espectramax Plus 384 (Molecular Devices) a $405 \mathrm{~nm}$. Os valores encontrados em cada soro foram comparados com o esperado para lisar 100\% de hemácias descontando-se o controle negativo (branco). A porcentagem de lise foi medida como segue:

$$
\begin{gathered}
\% \text { de lise }=\frac{\text { D.O amostra }- \text { D.O branco }}{\text { D.O } 100 \% 100} \text { Lise }- \text { D.O branco }
\end{gathered}
$$

Com este cálculo e preparo da curva, obtivemos o volume de soro necessário para lisar $50 \%$ de eritrócito. Este volume definirá uma unidade $\mathrm{CH} 50$. O ensaio da atividade hemolítica da via clássica foi feita em duplicata.

\subsection{Cultura de fibroblastos e estimulação com LPS}

A partir da biópsia da pele, os fibroblastos foram cultivados em estufa de $\mathrm{CO}_{2}(5 \%)$ a $37{ }^{\circ} \mathrm{C}$, em meio de cultura DEMEM, enriquecido com 10\% de SFBi e 1\% de glutamina.

Após proliferação celular, os fibroblastos foram removidos com uma solução de tripsina 0,1\% ( $\mathrm{pH}=7,8$ contendo glicose 5,5 mM; $\mathrm{NaCl} 137 \mathrm{mM} ; \mathrm{KH}_{2} \mathrm{PO}_{4}$ 5,3 mM; $\mathrm{NaHCO}_{3}$ 4,2 mM e EDTA $0,5 \mathrm{mM}$ ). Amostras de $10^{6}$ células foram transferidas para garrafas de cultura de $75 \mathrm{~cm}^{2}$, onde foram cultivadas em estufa de $\mathrm{CO}_{2}(5 \%)$ a $37{ }^{\circ} \mathrm{C}$, em DEMEM enriquecido com $1 \%$ de glutamina $2 \mathrm{mM}$. Depois de $24 \mathrm{~h}$, as células foram estimuladas com $1 \mu \mathrm{g} / \mathrm{mL}$ de 
lipopolissacarídeo (LPS) de Escherichia coli- (Sigma-Aldrich, Saint Louis, Missouri, EUA) por 24 h. Estas células foram estimuladas entre os repiques R3 e o repique R8. Com este estímulo induzimos um aumento na expressão e secreção desta proteína pelos fibroblastos em cultura.

3.7 Extração de RNA de fibroblastos estimulados com LPS.

Após o estímulo dos fibroblastos com LPS, as células foram removidas com uma solução de tripsina e centrifugadas a 2000 x $g$ por 10 min a $4{ }^{\circ} \mathrm{C}$. Desprezado o sobrenadante, adicionamos $1 \mathrm{~mL}$ de Trizol® Reagent (Life Technologies) e após ação mecânica lisamos as células. Depois de manter a preparação por 5 min à temperatura ambiente, adicionamos $200 \mu \mathrm{L}$ de clorofórmio (Merck, São Paulo, SP, Brasil), passamos o tubo em vórtex por $15 \mathrm{~s}$, e incubamos novamente por 5 min à temperatura ambiente. Centrifugamos cada amostra a $12.000 \mathrm{x} g$ por 15 min a $4{ }^{\circ} \mathrm{C}$ para, dessa forma, separar o RNA total dos demais componentes na camada superior incolor. Em um tubo estéril, recolhemos aproximadamente $2 \mathrm{~mL}$ de suspensão, adicionamos 500 $\mu \mathrm{L}$ de isopropanol (Merck), e misturamos cuidadosamente o conteúdo três vezes por inversão. Feito isso, incubamos por 10 min à temperatura ambiente seguido por centrifugação em $12.000 \mathrm{x}$ $g$ por 10 min a $4{ }^{\circ} \mathrm{C}$. Após desprezar o sobrenadante, lavamos o precipitado com $1 \mathrm{~mL}$ de etanol $75 \%$ por centrifugação a 7.500 x $g$ por 5 min a $4{ }^{\circ} \mathrm{C}$. Secamos o precipitado em cabine de segurança biológica, e adicionamos $15 \mu \mathrm{L}$ de UltraPure DNase/RNase-Free (Invitrogen, São Paulo, SP, Brasil). Incubamos o RNA por $10 \mathrm{~min}$ a $55{ }^{\circ} \mathrm{C}$ para dissolver o precipitado (Chirgwi et al.,1979). A concentração e integridade do RNA total extraído foi determinada por Nanodrop 2000 (Spectrophtometer Thermo Scientific, Wilmington, Estados Unidos, USA) aceitando-se a pureza relativa (D.O. $260 \mathrm{~nm} /$ D.O. $280 \mathrm{~nm}$ ) entre 1,8 e 2,0. Após a quantificação do RNA total, procedemos com a etapa abaixo.

3.8 Extração de DNA genômico de fibroblastos

As células $\left(10^{6}\right)$ foram destacadas da garrafa de cultura com uma solução de tripsina $0,01 \%$ e centrifugadas a $2000 \times \mathrm{g}$ por $10 \mathrm{~min}$ a $4{ }^{\circ} \mathrm{C}$. A extração foi feita utilizando $o$ kit Illustra 
tissue \& cells genomic Prep Mini Spin Kit (GE Healthcare, Inglaterra, Reino Unido), conforme indicação do fabricante.

3.9 Síntese de cDNA empregando transcriptase reversa e amplificação por reação em cadeia utilizando DNA polimerase (RT-PCR)

A síntese de cDNA foi feita utilizando o kit M-MLR Reverse Transcriptase (28025-013 Invitrogen), Oligo (dT) 12-18 Primer (18418-012 Invitrogen) e RNaseOUT ${ }^{\mathrm{TM}}$ (10777-019 Invitrogen), conforme indicação do fabricante. A reação foi submetida ao seguinte programa: Etapa 1: $65^{\circ} \mathrm{C}$ por $5 \mathrm{~min}$, Etapa 2: $0{ }^{\circ} \mathrm{C}$ por $1 \mathrm{~min}$, Etapa $3: 37^{\circ} \mathrm{C}$ por $2 \mathrm{~min}$, Etapa 4: $25^{\circ} \mathrm{C}$ por $10 \mathrm{~min}$, Etapa $5: 37^{\circ} \mathrm{C}$ por $50 \mathrm{~min}$, e Etapa $6: 70{ }^{\circ} \mathrm{C}$ por $15 \mathrm{~min}$.

A amplificação por RT-PCR foi feita utilizando o kit Illustra ${ }^{\mathrm{TM}}$ Taq DNA Polymerase (GE Healthcare), conforme indicação do fabricante, com pares de iniciadores para o gene C3 e fragmento de DNA genômico (Tabela 3). Para a amplificação propriamente dita empregamos o seguinte programa: Etapa 1: $94{ }^{\circ} \mathrm{C}$ por $5 \mathrm{~min}$, Etapa 2: $94{ }^{\circ} \mathrm{C}$ por $30 \mathrm{~s}$, Etapa 3: $54{ }^{\circ} \mathrm{C}$ por $30 \mathrm{~s}$, Etapa 4: $72{ }^{\circ} \mathrm{C}$ por $1 \mathrm{~min}$, Etapa 5: 39 repetições dos passos 2 ao 4 e, por fim, Etapa 6: $72{ }^{\circ} \mathrm{C}$ por 7 min. Para essas reações utilizamos o termociclador PTC 100 TM Programmable Thermal Controller (MJ Research Inc, Watertown, Estados Unidos, USA).

Os resultados foram analisados após eletroforese em gel de agarose 1\% em tampão $1 \mathrm{X}$ (TBE pH 8,0, ácido bórico $89 \mathrm{mM}$, Tris-HCl $89 \mathrm{mM}$ e 0,4\% de EDTA 0,5 M ph=8,0). A coloração do gel foi feita com Sybr Safe DNA gel stain (Invitrogen). Ao término da corrida, o gel foi observado no ImageQuant 300 (GE Life Sciences, Inglaterra, Reino Unido), utilizando luz ultravioleta para evidenciar as bandas dos produtos amplificados. Também foram tiradas fotos dos géis de agarose utilizando este mesmo equipamento.

3.10 Purificação dos produtos de RT-PCR

A purificação do DNA foi feita utilizando o kit Illustra GFX PCR DNA and Gel Band Purification Kit (GE Healthcare). Em $100 \mu \mathrm{L}$ de reação PCR, adicionamos $500 \mu \mathrm{L}$ de tampão de captura e após homogeneizar o volume completo, é transferido para o sistema previamente 
montado de coluna de filtração. Centrifugamos por $30 \mathrm{~s}$ a 16000 x $g$ em temperatura ambiente e descartamos o conteúdo do tubo. Feito isso, adicionamos $500 \mu \mathrm{L}$ de tampão de lavagem na coluna, e centrifugamos por $30 \mathrm{~s}$ a 16000 x $g$ em temperatura ambiente. Descartamos o conteúdo do tubo, adicionamos $15 \mu \mathrm{L}$ de tampão de eluição na coluna, incubamos por $60 \mathrm{~s}$, e centrifugamos por $60 \mathrm{~s}$ a $16000 \mathrm{x} g$ em temperatura ambiente. A concentração e integridade do cDNA total extraído foi determinada empregando-se o equipamento Nanodrop 2000 (Spectrophotometer Thermo Scientific, Wilmington, Estados Unidos, USA), aceitando-se a pureza relativa (D.O. $260 \mathrm{~nm} /$ D.O. $280 \mathrm{~nm}$ ) entre 1,8 e 2,0. Após quantificação do cDNA total, foi realizada a reação de sequenciamento.

3.11 Sequenciamento do cDNA de C3 humano e DNA genômico do gene de C3

O sequenciamento dos fragmentos de cDNA e do próprio gene $C 3$ (Figura 5) foi feito utilizando-se entre $200 \mathrm{ng}$ e $300 \mathrm{ng}$ de DNA total, iniciadores específicos conforme Tabela 3, além de $\mathrm{H}_{2} \mathrm{O}$ Milli-Q estéril e a enzima BigDye (Invitrogen). Na reação de sequenciamento utilizamos apenas um dos oligos, e realizamos duas reações, uma reação foi amplificada no sentido 5'- 3' e outra no sentido 3'- 5'. 
Tabela 3 - Iniciadores e posição dos nucleotídeos (nt) utilizados para RT-PCR e reação de sequenciamento*.

\begin{tabular}{|c|c|c|c|}
\hline INICIADORES (nT) & SENTIDO & Sentido $5^{\prime} \rightarrow 3^{\prime}$ & $\operatorname{Tm}\left({ }^{\circ} \mathrm{C}\right)$ \\
\hline $1-21$ & $\mathrm{~F}$ & СТССТССССАТССТСТСССТС & 66 \\
\hline $530-599$ & $\mathrm{R}$ & TGTTGACCATGACCGTCCGGCCCACGGGTA & 66 \\
\hline $530-602$ & $F$ & GGTCAAGCAGGACTCCTTGTC & 55 \\
\hline $1063-1044$ & $\mathrm{R}$ & TGAGTGCAAGATGACGGTGG & 55 \\
\hline $834-855$ & $\mathrm{~F}$ & GTTCCTCTACGGGAAGAAAGT & 55 \\
\hline $1553-1531$ & $\mathrm{R}$ & CCCTTGTTCATGATCAGGTAGG & 58 \\
\hline $1540-1560$ & $\mathrm{~F}$ & ATCATGAACAAGGGCAGGCTG & 64 \\
\hline $2240-2220$ & $R$ & GCAGTCCAGGAAGACATTCTT & 64 \\
\hline 1841-1855 & $\mathrm{F}$ & TCATGGTGGCCGTGG & 55 \\
\hline $2643-2663$ & $\mathrm{R}$ & CTTGAGCTCTTGGTTCTGCC & 55 \\
\hline $2504-2523$ & $\mathrm{~F}$ & TCTGTGTGGCAGACCCCTTC & 58 \\
\hline 3194-3214 & $\mathrm{R}$ & CCTTCTTGATGAGCTCCAAGG & 58 \\
\hline 3011-3032 & $\bar{F}$ & TGGCCCAGATGACAGAGGATG & 60 \\
\hline $3413-3433$ & $\mathrm{R}$ & TCACGGGCGCATCCTCCTGGA & 60 \\
\hline 3308-3329 & $\mathrm{F}$ & GTCAAGGTCTTCTCTCTGGCT & 60 \\
\hline $3960-3940$ & $R$ & CAGTTGGAGGGACACATCAAG & 66 \\
\hline 3839-3859 & $\mathrm{F}$ & GATACTACGGTGGTGGCTATG & 60 \\
\hline 4404-4425 & $\mathrm{R}$ & CTCAGAGTGTGAGACCTTGTCC & 60 \\
\hline 4278-4297 & $F$ & CATGATGACTGGCTTTGCTC & 64 \\
\hline $5067-5047$ & $\mathrm{R}$ & GGAATGGGGGTGTGGTCAGTT & 64 \\
\hline 6690961 & $F$ & GGATCAGACCGTTGTACCCATT & 60 \\
\hline 6690313 & $\mathrm{R}$ & GCAGACAGAAAGAATCCCCACC & 60 \\
\hline
\end{tabular}

Sentidos dos iniciadores integrado $(\mathrm{F})$ e retrógrado $(\mathrm{R})$, temperatura de hibridação $\left(\mathrm{Tm}^{\circ} \mathrm{C}\right)$. 

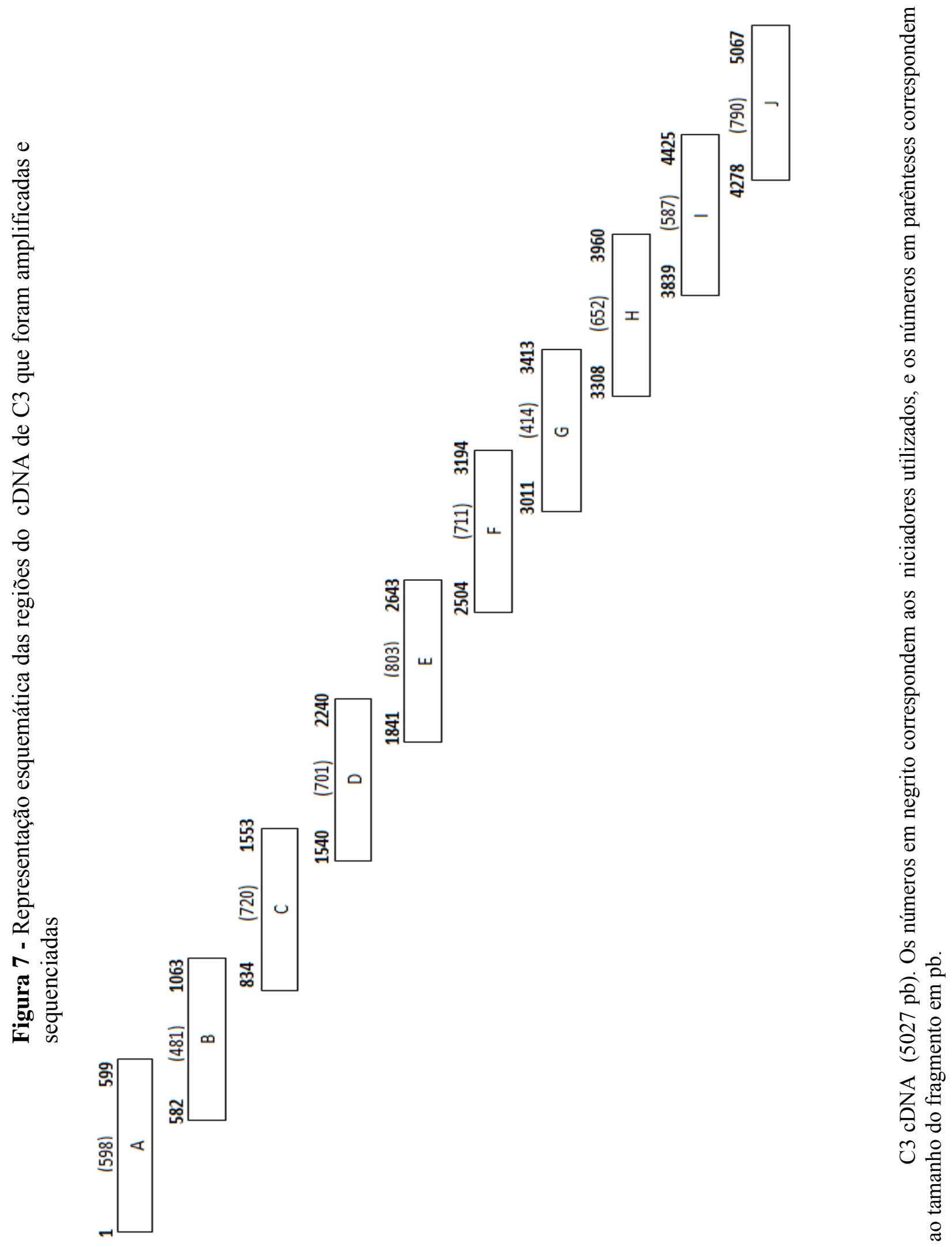
A reação de sequenciamento do cDNA foi realizada com o seguinte programa: Etapa 1: $96{ }^{\circ} \mathrm{C}$ por $2 \mathrm{~min}$, Etapa 2: $96^{\circ} \mathrm{C}$ por $45 \mathrm{~s}$, Etapa 3: $50{ }^{\circ} \mathrm{C}$ por $30 \mathrm{~s}$, Etapa 4: $60{ }^{\circ} \mathrm{C}$ por 4 min, Etapa 5: 39 repetições dos passos 2 ao 4 e, por fim, Etapa 6: $60^{\circ} \mathrm{C} 4 \mathrm{~min}$. Em seguida, as amostras foram precipitadas com $80 \mu \mathrm{L}$ de isopropanol $75 \%$ à temperatura ambiente por 15 min, e centrifugada por $20 \mathrm{~min}$ a $8000 \mathrm{x}$. As amostras foram lavadas com $200 \mu \mathrm{L}$ de isopropanol $75 \%$ e centrifugadas por $5 \mathrm{~min} 8000 \mathrm{x}$. Ao final, o isopropanol foi descartado permitindo que as amostras secassem. A corrida eletroforética para o sequenciamento de nucleotídeos foi realizada no Departamento de Bioquímica no Instituto de Química da USP, empregando o sequenciador ABI PRISM 3100 Genetic Analyzer/HITACHI (Applied Biosystems Foster, Carlsbad, Califórnia, EUA). As sequências obtidas do cDNA e do DNA genômico foram comparadas com os dados depositados no site http://www.ncbi.nlm.nih.gov/blast, utilizando o programa BLAST N (Altschul et al., 1997) com a referência /NM 000064.1/ C3/ Homo sapiens complement component 3 (C3) mRNA para cDNA de C3 (De Bruijn, Fey 1985) e http://www.ensembl.org/Homo_sapiens/Gene/Sequence?db=core;g=ENSG00000125730;r=19:66 77715-6730573 para DNA genômico. Todas as sequências foram analisadas por meio do programa Bio Edit.

\subsection{Concentração de sobrenadante de fibroblastos estimulado com LPS}

A partir da biópsia da pele, os fibroblastos foram cultivados em estufa de $\mathrm{CO}_{2}(5 \%)$ a $37{ }^{\circ} \mathrm{C}$, em meio de cultura DEMEM, enriquecido com 10\% de SFBi e 1\% de glutamina.

Após proliferação celular, os fibroblastos foram removidos com uma solução de tripsina 0,1\% ( $\mathrm{pH}=7,8$ contendo glicose 5,5 mM; $\mathrm{NaCl} 137 \mathrm{mM} ; \mathrm{KH}_{2} \mathrm{PO}_{4}$ 5,3 mM; $\mathrm{NaHCO}_{3}$ 4,2 mM e EDTA $0,5 \mathrm{mM}$ ). Amostras de $10^{6}$ células foram transferidas para garrafas de cultura de $75 \mathrm{~cm}^{2}$, onde foram cultivada em estufa de $\mathrm{CO}_{2}(5 \%)$ a $37{ }^{\circ} \mathrm{C}$, em DEMEM enriquecido com $1 \%$ de glutamina $2 \mathrm{mM}$. Depois de $24 \mathrm{~h}$, as células foram estimuladas com $1 \mu \mathrm{g} / \mathrm{mL}$ de lipopolissacarídeo (LPS) de Escherichia coli- (Sigma-Aldrich, Saint Louis, Missouri, EUA) por 24 h. Passado esse período, o sobrenadante foi coletado em tubo estéril (30 $\mathrm{mL}$ total) e concentrado (30 vezes) em sistema de ultrafiltragem Amicon® Ultra centrifugal Filters Ultracel 30K (Merck S.A ). Feito isso, quantificamos as proteínas totais utilizando o kit BCA TM Protein 
Assay Kit (Thermo Scientific), conforme indicação do fabricante. Posteriormente as amostras foram submetidas à técnica de Western blotting.

\subsection{Western blotting}

As amostras de soro da família da paciente foram submetidas à eletroforese em gel (SDS-PAGE) 10\% em tampão de corrida Tris glicina (Tris-HCl $25 \mathrm{mM}$, glicina $192 \mathrm{mM} \mathrm{e}$ SDS $0,1 \%$, pH 8,3), por um período de $30 \mathrm{~min}$ em $60 \mathrm{~V}$, e por mais $1 \mathrm{~h}$ em $120 \mathrm{~V}$.

Após a corrida eletroforética, o gel foi transferido para uma membrana de nitrocelulose (7,5 cm por 9,0 cm Hybond ECL Nitrocellulose Membrane, Amersham Biosciences, GE Healthcare), e transferido usando a solução (Tris-HCl 25 mM pH=8,3, glicina 192 mM, SDS 0,02\% e etanol 20\%), por $1 \mathrm{~h}$ a 350 A. Os sítios de ligação inespecíficos foram bloqueados com $10 \%$ de leite desnatado em tampão fosfato (cloreto de potássio 2,7 mM, cloreto de sódio $137 \mathrm{mM}$, fosfato dibásico de sódio $10 \mathrm{mM}$ e fosfato monobásico de potássio $1,7 \mathrm{mM}, \mathrm{pH}$ =7,4[PBS]) com detergente Tween 0,05\% (PBS contendo Tween 20 0,05\% [PBS-T]) por $18 \mathrm{~h}$ a $4{ }^{\circ} \mathrm{C}$. Após 3 lavagens por 3 min com PBS-T, as membranas foram incubadas com anti-C3 humano policlonal produzido em cabra (Complement Technology) diluído 1:5000, por $1 \mathrm{~h} \mathrm{em}$ 10\% de leite desnatado em PBS-T. Depois da incubação, lavamos a membrana 3 vezes por 5 min com PBS-T, e a incubamos com anti-IgG de cabra (policlonal) produzido em coelho (KPL) conjugado à peroxidase $(1: 10000)$ por $1 \mathrm{~h}$ em $10 \%$ de leite desnatado em PBS-T. Novamente lavamos a membrana com PBS-T por 5 min por 3 vezes. A revelação foi feita com ECL (Enhanced Chemiluminescence System, Amersham) (Thermo Scientific) segundo instruções do fabricante. A densitometria foi feita utilizando o programa Image J. 


\section{RESULTADOS}

4.1 Análise da concentração de proteínas por imunodifusão radial

A concentração reduzida de C3 pode ser observada tanto em pacientes com deficiência deficiência primária de C3 ou como consequência da deficiência FI ou FH. Estas proteínas são fundamentais para a regulação da alça de amplificação da via alternativa. Na ausência de uma delas, há um consumo exagerado de C3 e redução dos níveis séricos de FB (Walport, 2001). Para eliminar esta hipótese e averiguar que se tratava realmente de deficiência primária de $\mathrm{C} 3$, nosso primeiro passo foi quantificar a concentração dessas proteínas, conforme Tabela 4.

Tabela 4 - Quantificação da concentração sérica de proteínas FB, FH, FI e C3 por imunodifusão radial

\begin{tabular}{ccccc}
\hline Fator pesquisado & FB $\mathbf{~ m g ~} / \mathbf{m L}$ & FH $\mathbf{~ m g} / \mathbf{m L}$ & FI $\mathbf{~ m g} / \mathbf{m L}$ & $\mathbf{C 3 ~} \mathbf{m g} / \mathbf{m L}$ \\
\hline Paciente & 0,26 & 0,57 & 0,043 & Ausente \\
Pai & 0,17 & 0,47 & 0,051 & $\mathbf{0 , 5 2}$ \\
Mãe & 0,25 & 0,38 & 0,044 & $\mathbf{0 , 1 8}$ \\
Irmão & 0,35 & 0,48 & 0,040 & $\mathbf{0 , 3 7}$ \\
\hline $\begin{array}{c}\text { Mistura de soro de } \\
\text { 50 indivíduos } \\
\text { normais }\end{array}$ & $\mathbf{0 , 2 2}$ & $\mathbf{0 , 4 4}$ & $\mathbf{0 , 0 4 7}$ & $\mathbf{1 , 4 0}$ \\
\hline
\end{tabular}

\begin{tabular}{|c|c|c|c|c|}
\hline Média & $\mathbf{0 , 3 4}$ & $0,60 \pm 0,26$ & $0,058 \pm 0,016$ & 0,90 \\
\hline $\begin{array}{l}\text { Intervalo de } \\
\text { normalidade }\end{array}$ & $0,21-0,59$ & $0,23-1,31$ & $0,030-0,103$ & $0,61-1,41$ \\
\hline Faixa etária & $5-6$ anos & $1-5$ anos & 1-5 anos & $3-4$ anos \\
\hline Referências & $\begin{array}{c}\text { Ferriani et al } \\
1999\end{array}$ & $\begin{array}{c}\text { Ferreira de } \\
\text { Paula et al } 2003\end{array}$ & $\begin{array}{c}\text { Ferreira de } \\
\text { Paula et al } 2003\end{array}$ & $\begin{array}{c}\text { Ferriani et al } \\
1999\end{array}$ \\
\hline
\end{tabular}

No momento da coleta de soro a paciente tinha 3 anos de idade.

Observamos que os níveis de FB, FH e FI no soro da paciente A.S.S encontram-se dentro do intervalo de normalidade (Ferriani et al., 1999; Ferreira de Paula et al., 2003). O soro do pai apresentou concentração de FB abaixo da média, e do intervalo de normalidade. Já os níveis da 
proteína $\mathrm{C} 3$ de todos os membros da família se mostraram abaixo do esperado para um indivíduo normal, e em especial no soro da paciente esta proteína não foi detectável, sugerindo um padrão de herança autossômica recessiva, conforme heredograma abaixo.

Figura 8 - Heredograma da família objeto de estudo

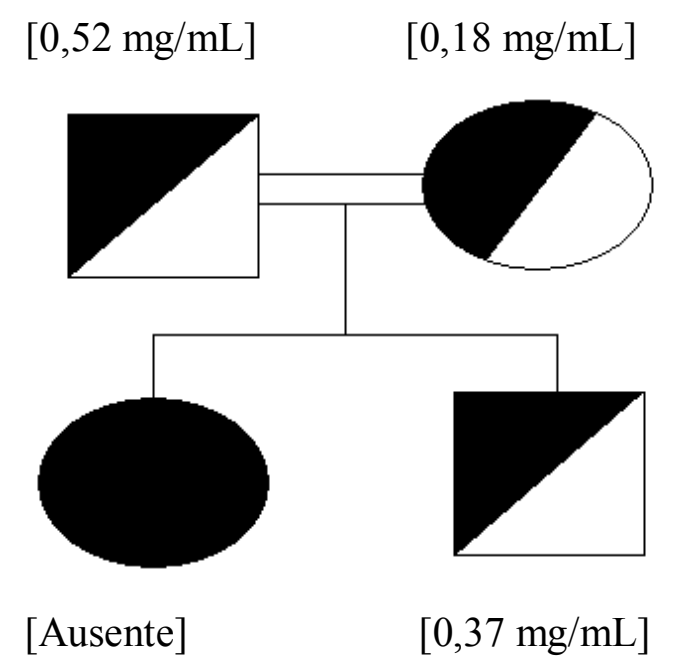

Heredograma da família objeto de estudo. $\boldsymbol{V}$ indivíduo heterozigoto do sexo masculino. $\bullet$ indivíduo heterozigoto do sexo feminino. $\square$ indivíduo do sexo masculino. • paciente afetada. Barra dupla indica consanguinidade (pais são primos em primeiro grau). [] indica a concentração da proteína C3 no soro. Valor normal de C3 para adultos: 1,3 mg/mL (Vick et al., 1991).

4.2 Análise da atividade hemolítica mediada pela via alternativa do sistema complemento

Com o intuito de verificar a funcionalidade da via alternativa, avaliamos a capacidade do soro em ativar o complemento e lisar hemácias de coelho, conforme a Tabela 5. 
Tabela 5 - Atividade hemolítica mediada pela via alternativa do sistema complemento

\begin{tabular}{cc}
\hline Indivíduos & AP50 U/mL \\
\hline Paciente & zero \\
Pai & 75,6 \\
Mãe & 82,5 \\
Irmão & 69,0 \\
Mistura de soro de 50 indivíduos & 130,5 \\
normais & \\
\hline Valor de referência & $\mathbf{1 0 6 , 1 + / - 2 7 , 1 ~ U / m L}$ \\
\hline
\end{tabular}

4.3 Análise da atividade hemolítica mediada pela clássica do sistema complemento

Nós também verificamos a capacidade de ativação da via clássica do complemento, conforme a Tabela 6.

Tabela 6 - Atividade hemolítica mediada pela via clássica do sistema complemento

\begin{tabular}{cc}
\hline Indivíduos & CH50 U/mL \\
\hline Paciente & zero \\
Pai & 61,5 \\
Mãe & 133,1 \\
Irmão & 229,5 \\
Mistura de soro de 50 indivíduos & 606,9 \\
normais & \\
\hline Valor de referência & $628,3+/-130,3 \mathrm{U} / \mathbf{m L}$ \\
\hline
\end{tabular}

Os dados indicaram que as atividades hemolíticas mediadas pela via alternativa, assim como pela via clássica, no soro de todos os membros da família estavam abaixo dos níveis normais, quando comparados a uma mistura de soro de 50 indivíduos normais, e abaixo dos valores de normalidade previamente estabelecidos em nosso laboratório. Em acordo com esta observação, a concentração sérica da proteína C3 dos membros da família também é menor, quando comparada com a de uma mistura de soro de 50 indivíduos normais, e abaixo do intervalo de normalidade.

Esses dados são coerentes com a suposição que os pais são heterozigotos para deficiência da proteína C3 encontrada na paciente, embora seja necessário o sequenciamento genético para esta confirmação. 
4.4 Análise por Western blotting da presença de C3 nos soros da família e análise densitométrica

Em seguida nós analisamos por Western blotting a presença de C3 no soro de cada membro da família, e de um indivíduo controle, conforme mostrado na Figura 9.

Figura 9 - Análise por Western blotting da presença de C3 no soro da família

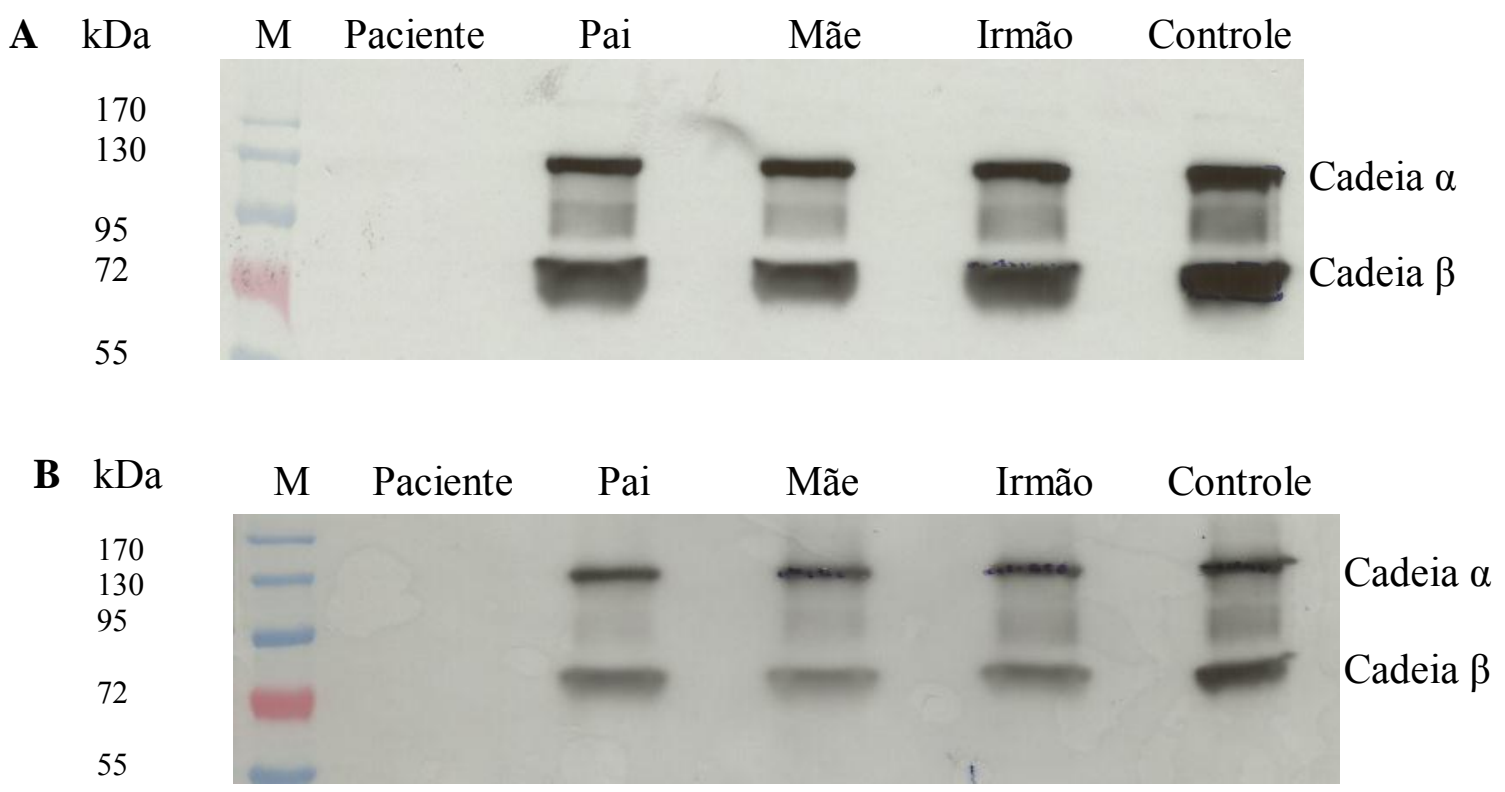

Cadeia $\alpha$ de C3 com 115 kDa e Cadeia $\beta$ com 75 kDa. SDS-PAGE (10\%); empregamos anti-C3 humano (1:5000) e anti-IgG conjugado a peroxidase (1:10000). $\mathbf{A}=$ Soro da paciente $(400 \mathrm{ng} / \mu \mathrm{L})$ e demais soros $(200 \mathrm{ng} / \mu \mathrm{L})$ de proteína total. B igual volume $(0,22 \mu \mathrm{L})$ de cada soro foi aplicado do gel. Controle: soro humano de indivíduo normal $\mathrm{M}=$ marcador de peso molecular. 
Tabela 7 - Análise densitométrica

\begin{tabular}{ccc}
\hline & Densidade (UA) & \% C3 $^{\mathbf{b}}$ \\
\hline Paciente & $0,0 \pm 0,0$ & 0,0 \\
Pai & $108,3 \pm 2,1$ & 70,6 \\
Mãe & $113,2 \pm 2,1$ & 73,8 \\
Irmão & $126,9 \pm 2,2$ & 82,8 \\
Normal & $152,1 \pm 1,7$ & ---- \\
\hline
\end{tabular}

${ }^{a}$ A densidade de cada banda foi representada em unidades arbitrárias (UA) e mensurada usando o programa Image J. Os números correspondem à média de três experimentos independentes (média \pm desvio padrão).

${ }^{\mathrm{b}} \mathrm{O}$ percentual de $\mathrm{C} 3$ foi calculado considerando-se como $100 \%$ os valores obtidos com o indivíduo controle considerando a soma da intensidade das duas bandas equivalente as duas cadeias $\alpha$ e $\beta$ de $\mathrm{C} 3$, representadas na figura 9B.

Nós confirmamos a ausência da proteína C3 no soro da paciente (Figura 9), mesmo utilizando uma concentração duas vezes maior de proteínas $(400 \mathrm{ng} / \mu \mathrm{L}$ para a paciente e 200 $\mathrm{ng} / \mu \mathrm{L}$ para os demais indivíduos). Interessante notar que as bandas correspondentes a ambas cadeias $\alpha$ e $\beta$ de $\mathrm{C} 3$ nos soros dos demais membros da família são relativamente menos intensas que as do indivíduo controle, embora esta não seja uma técnica quantitativa. O mesmo se repetiu quando realizamos o mesmo experimento com igual volume de soro para todos os membros da família e um indivíduo controle. Observamos pela densitometria feita a partir da análise por Western blotting da Figura 9B que o resultado foi zero quando comparada a banda do indivíduo controle.

A próxima etapa do nosso trabalho foi investigar as bases moleculares da deficiência da proteína $\mathrm{C} 3$ na paciente deficiente. Para isso nós estimulamos uma cultura de fibroblastos obtidos a partir de biópsia da pele da paciente e de um indivíduo controle. Após tratamento com LPS por 24 h, extraímos o RNA total por Trizol, conforme descrito em Materiais e Métodos. Utilizando pares de iniciadores específicos (Tabela 3), amplificamos as regiões do pró-C3 cDNA, conforme indicado na Figura 7 por RT-PCR. 
4.5 Análise do gel de agarose com regiões do cDNA de C3 amplificados por RT-PCR

Figura 10 - Eletroforese em gel de agarose (1\%) dos fragmentos de C3 cDNA amplificados por RT-PCR
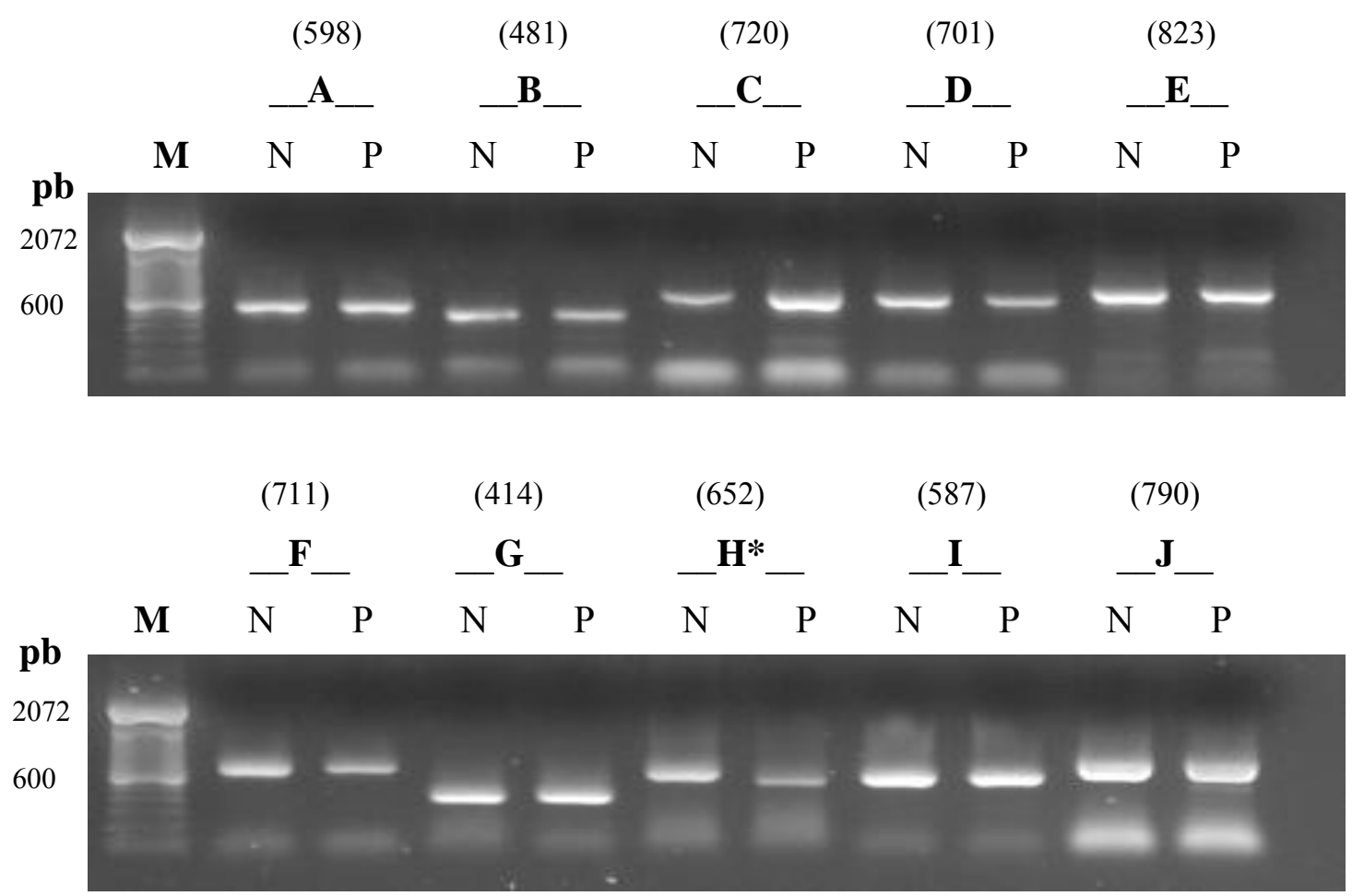

Em parênteses está indicado o tamanho de cada fragmento em pares de base (pb). Em negrito estão representadas as letras equivalentes a cada fragmento (conforme Figura 9). $\mathrm{N}$ indica indivíduo normal e P indica paciente deficiente. Região $\mathrm{H}^{*}$ correspondente à região afetada. $\mathbf{M}$ indica o marcador de tamanho.

Quando analisamos os fragmentos amplificados por RT-PCR, observamos que a banda correspondente ao fragmento $\mathrm{H}$ do cDNA do $\mathrm{C} 3$ da paciente migrou mais rapidamente do que a banda correspondente ao indivíduo controle (Figuras 10 e 11), indicando com isso que se trata de uma região com possível deleção de nucleotídeos.

4.6 Análise do gel de agarose do fragmento H amplificado por RT-PCR

Nosso passo seguinte foi amplificar novamente a região $\mathrm{H}$ do cDNA do C3 da paciente, demais membros da família e do indivíduo controle. Em seguida, submetemos o produto desta amplificação a uma nova corrida eletroforética (Figura 11). 
Figura 11 - Eletroforese em gel de agarose (1\%) com fragmentos amplificados por RT-PCR da região H (3308-3960 nt) do cDNA de C3

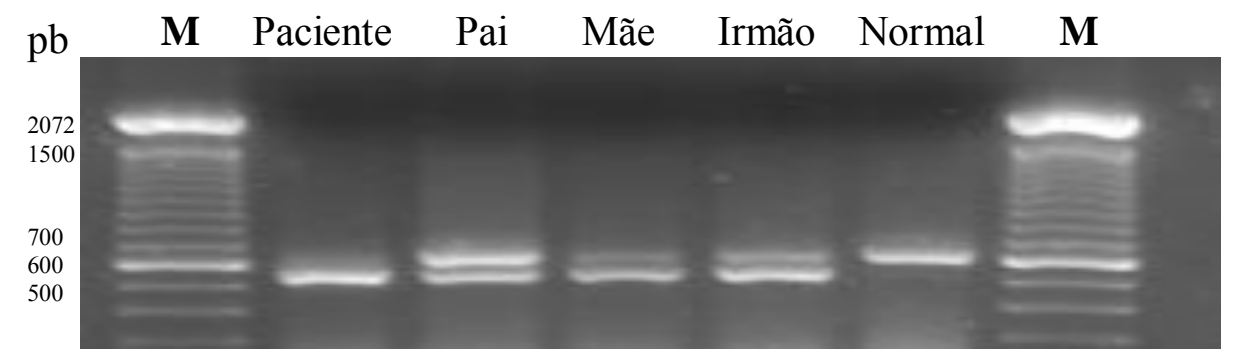

Controle normal com 652pb; paciente deficiente com 553pb. $\mathrm{M}=$ marcador de peso molecular.

Após a corrida eletroforética, observamos diferença entre o tamanho das bandas do fragmento $\mathrm{H}$ dos membros desta família e o controle normal. O cDNA de C3 de indivíduo normal gerou uma única banda de 652 pb, enquanto do pai e da mãe amplificaram duas bandas, uma com $652 \mathrm{pb}$ equivalente ao alelo normal e outra com $553 \mathrm{pb}$ equivalente ao alelo mutado, confirmando a heterozigose para o gene $C 3$. O cDNA de C3 do irmão também gerou duas bandas (652 pb e $553 \mathrm{pb}$ ) assim como os pais, já a paciente apresentou apenas uma banda com 553 pb produto de ambos os alelos mutados.

Depois desta análise, sequenciamos todo os nucleotídeos do C3 cDNA e parte do gene $C 3$.

4.7 Análise do sequenciamento genético da região $\mathrm{H}$ do cDNA de $\mathrm{C} 3$ e do gene $C 3$

Ao analisar o sequenciamento dos nucleotídeos do C3 de cDNA da paciente dos fragmentos A, B, C, D, E, F, G, I e J (Figura 7) não foram encontradas mutações, porém o sequenciamento do fragmento $\mathrm{H}$ indicou a sequência contínua do éxon 26 com o éxon 28, deleção completa do éxon 27, conforme mostra a Figura 12. 
Figura 12 - Sequenciamento dos nucleotídeos do fragmento H do cDNA de C3
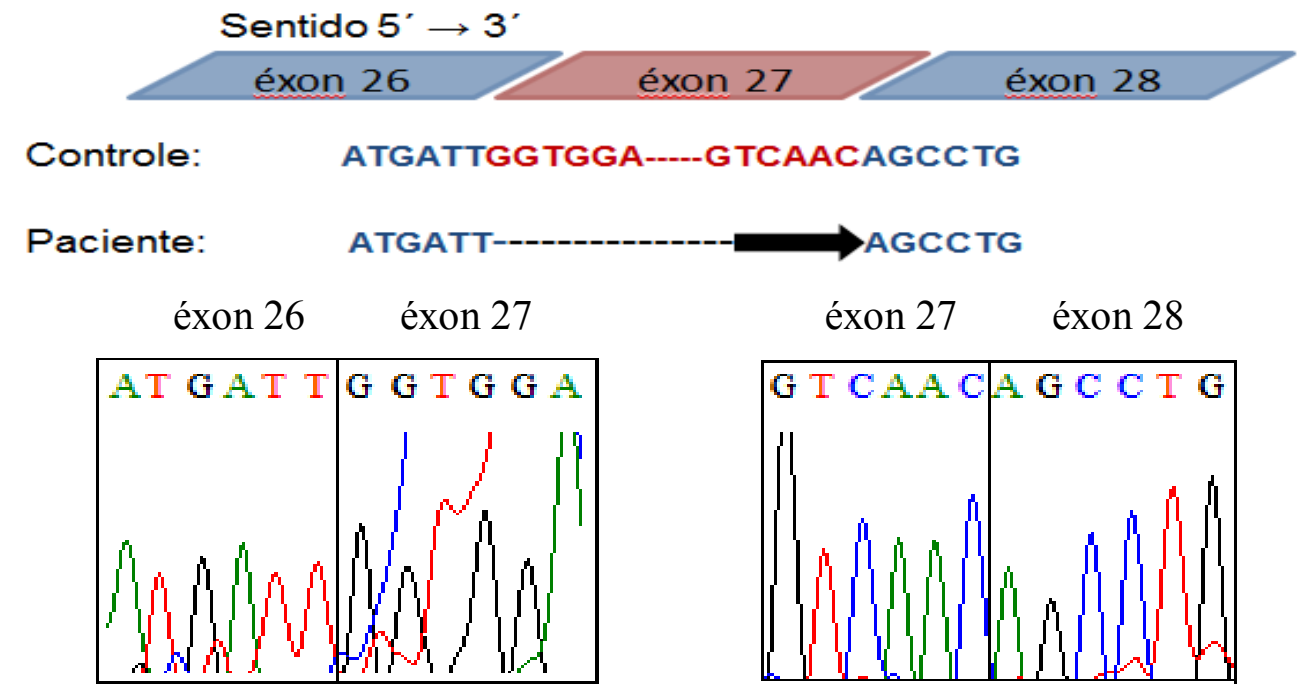

B: Normal

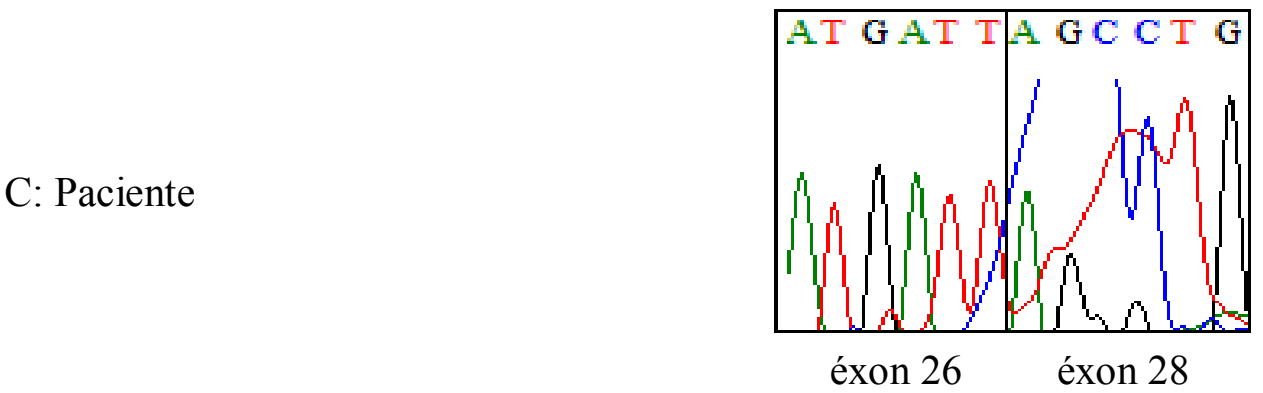

Sequenciamento dos nucleotídeos 3308 a 3960 (fragmento H) do cDNA de C3 $\left(5^{\prime} \rightarrow 3^{\prime}\right)$. Em A temos uma figura esquemática representando a junção do éxon 26, éxon 27 e éxon 28 do cDNA de C3 normal. Em B temos a junção entre o éxon 26 e o éxon 27 de um indivíduo normal, e a junção entre o éxon 27 e o éxon 28 do mesmo indivíduo normal. Em $\mathbf{C}$ temos o éxon 26 e éxon 28 da paciente, portanto com deleção do éxon 27.

O éxon 27 é formado por uma sequência de 99 nucleotídeos posicionados entre 3450 e 3549 do cDNA do C3. Esta região codifica para 33 aa (posição 1131-1163 na cadeia $\alpha$ de C3), e sua ausência pode implicar em sérias consequências para estabilidade e secreção da proteína C3 do complemento humano.

Com o intuito de verificar se a deleção do éxon 27 de C3 da paciente seria causada pela mutação em um nucleotídeo localizado nas sequências intrônicas conservadas GT-AG do gene C3, nós realizamos o sequenciamento genético dessas regiões empregando DNA genômico conforme Figura 13. 
Figura 13 - Sequenciamento dos nucleotídeos da região 6690313 até 6690961 do gene C3 correspondendo aos limites do íntron 26-éxon 27 e éxon 27-íntron 27

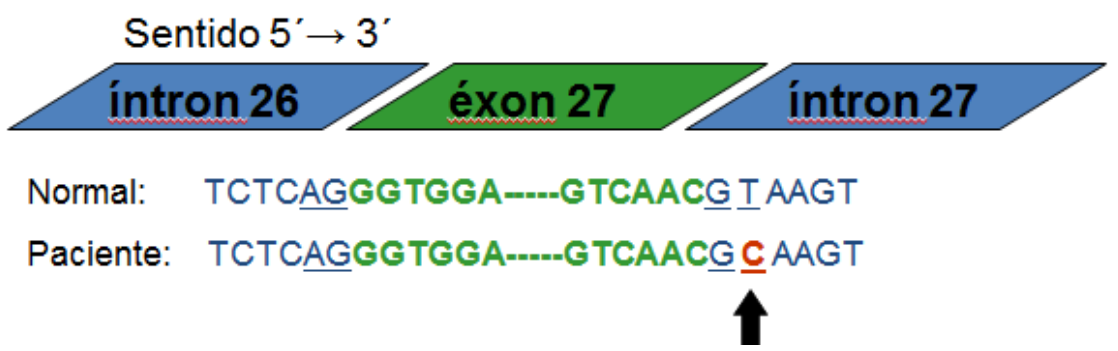

Normal
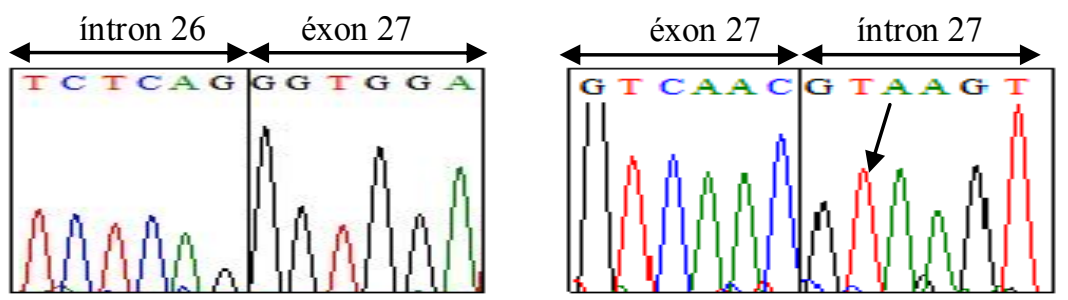

Pai
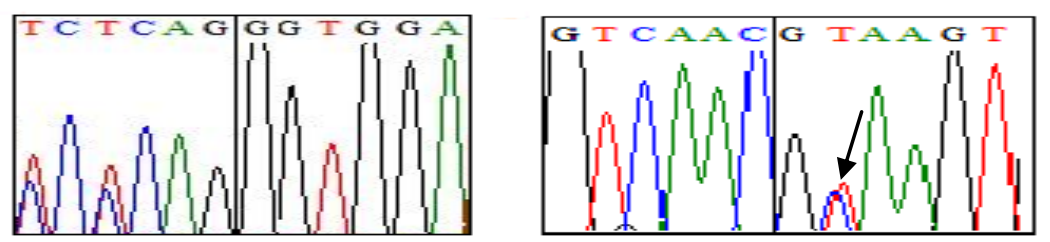

Mãe
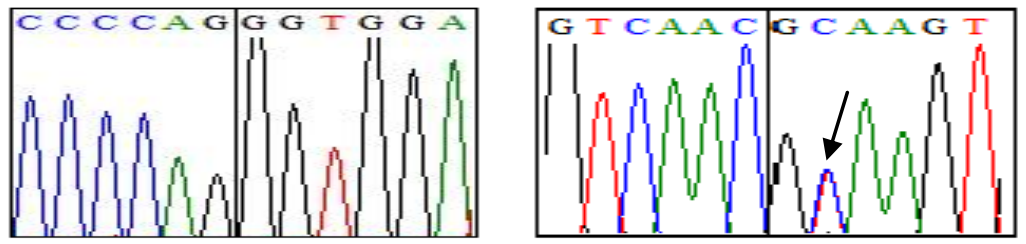

Irmão
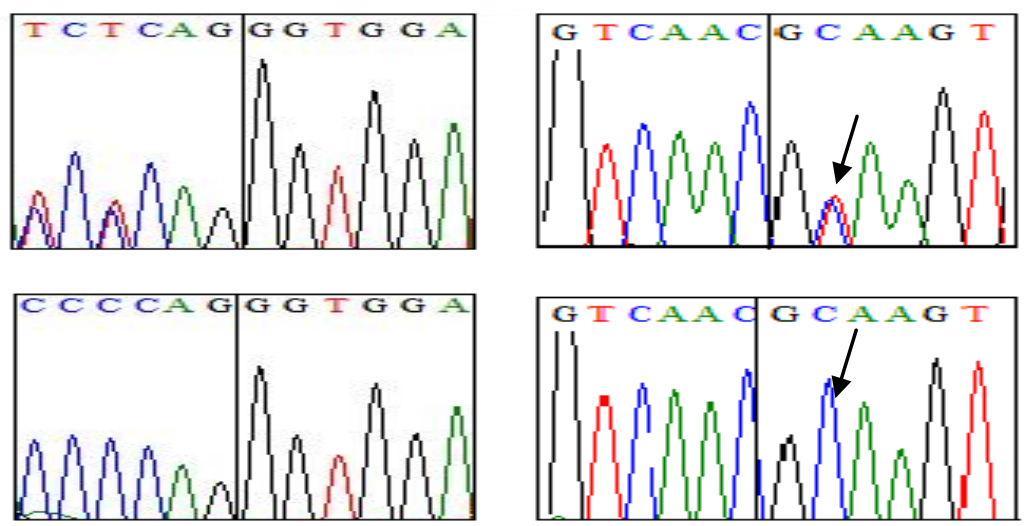

Em A temos representação da junção do íntron 26, éxon 27 e íntron 27. Em $\mathbf{B}$ temos as sequências AG intrônicas (íntron 26- éxon 27) e a sequência GT (éxon 27- íntron 27). As setas mostram dois picos (heterozigose) no gene $C 3$ dos pais, e irmão enquanto a paciente apresentou apenas um único pico (homozigose) (GT $\rightarrow \mathrm{GC}$ ), quando comparado ao gene de $C 3$ do indivíduo normal. 
Ao analisar o sequenciamento do gene na posição 6690626 do genoma humano, observamos a troca do nucleoídeo $\mathrm{T}$ por um $\mathrm{C}(\mathrm{T} \rightarrow \mathrm{C})$ na paciente, quando comparado ao indivíduo controle, o que acreditamos explica a causa da deficiência da proteína C3 na A.S.S. Esta mutação gera um splicing alternativo que excluí o éxon 27 do RNAm do cDNA do C3, que pode levar a síntese de uma proteína mutante que é degradada ainda dentro da célula.

4.8 Análise por Western blotting da presença de C3 no sobrenadante em cultura de fibroblastos estimulados com LPS da família

Com o intuito de verificar a hipótese da síntese de uma proteína instável que poderia sofrer degradação intracelular, nós cultivamos fibroblastos da paciente, sua família e de um indivíduo controle. Após estimulação com LPS por 24 h, nós coletamos o sobrenadante, concentramos por ultracentrifugação e, em seguida, analisamos a presença de C3 por Western blotting.

Figura 14 - Análise por Western blotting de sobrenadante de fibroblastos estimulados com LPS por $24 \mathrm{~h}$

$$
\text { Paciente Pai Mãe Irmão Normal }
$$

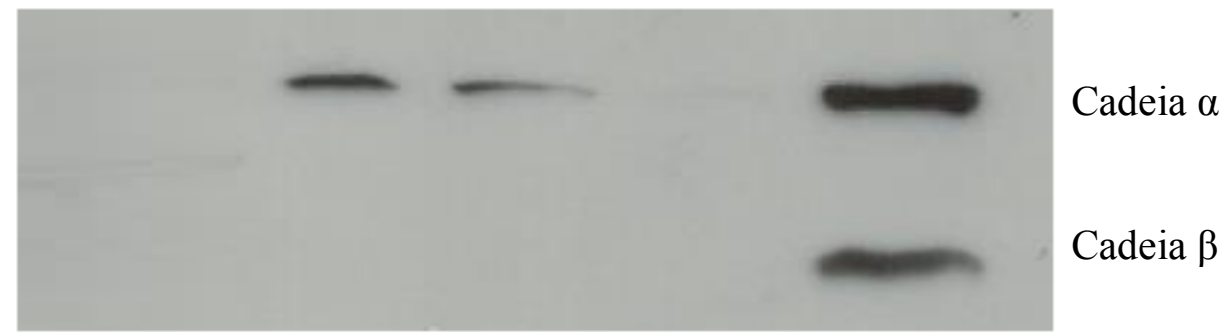

Cadeia $\alpha$ com $115 \mathrm{kDa}$ e Cadeia $\beta$ com $75 \mathrm{kDa}$. Gel SDS-PAGE (10\%) utilizando anti-C3 humano (1:5000) e anti-IgG conjugado a peroxidase (1:10000).

Ao analisarmos por Western blotting o sobrenadante de fibroblastos estimulados com LPS, constatamos a presença da cadeia $\alpha$ e da cadeia $\beta$ de $\mathrm{C} 3$ no indivíduo normal. O pai apresentou a cadeia $\alpha$ assim como a mãe, e o irmão não apresentou esta cadeia. Acreditamos que a ausência da cadeia $\beta$ nos pais e das cadeias $\alpha$ e $\beta$ no irmão ocorreu devido a pouca quantidade de C3 
secretado pelos fibroblastos estimulados, e pela degradação sofrida pela proteína. Na paciente não foi possível identificar nenhuma das cadeias $\alpha$ ou $\beta$. Esta análise está sendo repetida no momento. 


\section{DISCUSSÃO}

O sistema complemento quando ativado gera importantes mecanismos efetores para a defesa contra patógenos, participando tanto da resposta imune inata quanto da resposta imune adquirida. Composto por aproximadamente 40 diferentes proteínas, a deficiência de qualquer uma delas pode levar muitas vezes a defeitos nas vias de ativação ou de regulação e assim trazer sérias consequências ao seu hospedeiro. A deficiência da proteína C3 é rara na população, e como componente central deste sistema, sua ausência causa infecções graves e repetidas por bactérias como Neisseria meningitidis, Haemophilus influenzae, Escherichia coli, Streptococcus pneumoniae, entre outros microorganismos (Reis et al., 2006).

O tratamento de pacientes deficientes de C3 é feito normalmente com a administração de antibióticos para eliminação do patógeno causador da infecção, porém o tratamento com infusão de plasma normal ou componentes purificados do complemento foi estudado em pacientes deficientes de C3 e FI, demostrando restaurar as funções imunológicas do paciente por cerca de 15 dias. Porém o risco de sensibilização do sistema imune pela produção de auto-anticorpos é muito alto possibilitando o desenvolvimento de doença auto-imune, o que torna tal tratamento empregado apenas em casos extremos (Alper et al 1970, Barrett, Boyle 1984; Ziegler et al., 1975). O mais indicado (somado a administração de antibióticos) ainda é a imunização (quando possível) contra patógenos, tratamento empregado na paciente que foi imunizada por vacina pneumocócica 7-valente e 23-valente, vacina meningocócica $\mathrm{A}+\mathrm{C}$ e influenza, como forma de protegê-la contra constantes infecções durante sua vida.

Neste trabalho estudamos as causas da deficiência da proteína C3 em uma paciente brasileira com histórico familiar de consanguinidade. De acordo com os nossos resultados, observamos que seu soro não apresentou atividade hemolítica mediada nem pela via alternativa e nem pela via clássica o que é comum nos casos de deficientes de $\mathrm{C} 3$. A concentração da proteína C3 no soro de todos os membros da família é reduzida, quando comparada a uma mistura de soro de 50 indivíduos normais, e abaixo do valor de referência (Ferriani et al., 1999, Healy et al., 1969). No soro da paciente não foi possível detectar a presença de C3 e o soro dos pais apresentou apenas $50 \%$ da concentração da proteína C3 e aproximadamente $50 \%$ de atividade hemolítica, sugerindo um padrão de herança autossômica recessiva. Esse padrão foi posteriormente confirmado quando o cDNA de C3 e certas regiões intrônicas de $C 3$ foram sequenciadas. A paciente é homozigota para a mutação $\mathrm{T} \rightarrow \mathrm{C}$ na região 6690626 do gene $C 3$, 
enquanto os pais e irmão são heterozigotos. Esses resultados são semelhantes aos encontrados em trabalhos de pacientes deficientes de C3 como os descritos por Osofsky et al., (1997), Davis et al., (1997), Hsieh et al., (1981) entre outros.

Sabendo-se da deficiência de C3 nós analisamos os soros da família, paciente e controle por Western blotting, comprovando a ausência dessa proteína na paciente. Ao analisar os fragmentos do cDNA de C3 amplificados por RT-PCR, observamos uma diferença de tamanho na banda correspondente à região $\mathrm{H}$ (posição 3308 a 3960 nt) (Figura 13). Constatamos que o produto amplificado do indivíduo normal possui uma única banda de $652 \mathrm{pb}$ correspondente aos dois alelos normais. A amplificação do cDNA de C3 do pai e da mãe gerou duas bandas, uma com 652 pb equivalente ao alelo normal e outra com 553 pb equivalente ao alelo mutado, confirmando a condição de heterozigose para o gene $C 3$ nesta família. O irmão também apresentou duas bandas (652 pb e 553 pb) assim como os pais, já a paciente apresentou apenas uma única banda com 553 pb (menor) equivalente aos dois alelos (materno e paterno) mutados. Já o sequenciamento de nucleotídeos da região $\mathrm{H}$ nos forneceu um dado muito importante: a continuidade do éxon 26 com o éxon 28, isto é, a deleção completa do éxon 27. A deleção de éxon também foi relatada por Huang e colaboradores em 1994, em que a paciente apresentava no RNAm de C3 a exclusão de 34 nt na região 3' do éxon 10 e substituição da base $\mathrm{G} \rightarrow \mathrm{T}$ no sítio doador de splicing do íntron 10 do gene $C 3$ gerando um códon de parada prematuro. Tsukamoto e sua equipe em 2005 descreveram o caso de um homem com mutação no sítio receptor (AG $\rightarrow \mathrm{GG}$ ) no íntron 39 com uma alteração de $38 \mathrm{nt}$, levando à deleção do éxon 30 do gene $C 3$.

A concentração sérica de $\operatorname{IgA}$, IgG e IgM da paciente A.S.S esteve dentro da faixa de normalidade para crianças de mesma idade. Neste estudo infelizmente não foram determinadas as concentrações séricas de sub-classe de IgG. Sabemos que soro de pacientes deficientes de C3 podem apresentar aproximadamente $8,2 \mu \mathrm{g} / \mathrm{mL}$ de $\mathrm{IgG} 4$, enquanto soro de indivíduos normais apresentam cerca de $292 \mu \mathrm{g} / \mathrm{mL}$ desta sub-classe (Bird, Lachmann, 1988). Mesmo considerandose que a concentração de IgG4 representa apenas $2 \%$ do total de $\operatorname{IgG}$, esta observação é importante, pois indica que C3 deve provavelmente influenciar a expressão dessa sub-classe de IgG. Hazlewood et al. (1991) estudaram os níveis séricos de anticorpos específicos para um polissacarídeo da cápsula bacteriana de pneumococos no soro de pacientes homozigotos deficientes de C1r, C2, C1INH, C5b-9 e C3 do complemento. O estudo mostrou que 3 dos 4 pacientes deficientes de C3 tiveram uma baixa produção de anticorpos específicos para o 
polissacarídeo da cápsula bacteriana de pneumococos, indicando a participação dessa proteína na resposta imunológica mediada pelas células B na produção de anticorpos específicos.

Waldmann e Lachmann (1975) analisaram a resposta in vitro de células do baço de ratos para linfócitos $\mathrm{T}$ dependentes e $\mathrm{T}$ independentes na presença ou ausência de soro humano. Os autores mostraram que in vitro a resposta de IgM e IgG específica para ambos os antígenos $\mathrm{T}$ dependente ou $\mathrm{T}$ independente é menor em meio livre de soro humano. Da mesma forma a resposta de anticorpos é menor quando em meio contendo soro humano com inibidor de C3b, mostrando a importância do complemento nessa resposta.

A contagem diferencial de leucócitos mostrou alteração nos linfócitos e basófilos que na época do exame estavam acima dos valores normais. Conforme Material e Métodos, a paciente foi internada com pneumonia por S. pneumoniae aos 2 anos de idade (época da coleta de sangue para realização do exame) o que pode explicar essa alteração e o aumento no número dessas células. A infecção por S. pneumoniae ocorre pela transposição das barreiras naturais do hospedeiro, colonização das células epiteliais da nasofaringe e proliferação nos alvéolos pulmonares. Sua colonização pode ser resultado da sobrevivência dessas bactérias à fagocitose por macrófagos alveolares, onde liberam substâncias inflamatórias como endotoxinas bacterianas. A secreção de anticorpos naturais pela mucosa do hospedeiro, a produção da proteína C-reativa e o sistema complemento possuem um papel importante contribuindo na resposta imune inata contra pneumococos. Na infecção por essas bactérias a secreção de $\operatorname{IgM}$ e o aumento na concentração da proteína C-reativa são capazes de ativar a via clássica do complemento resultando na formação dos fragmentos $\mathrm{C} 3 \mathrm{~b}$ e iC3b que participam ativamente do processo de fagocitose, além da geração de $\mathrm{C} 5 \mathrm{a}$ que medeia o recrutamento de leucócitos para o foco inflamatório e a formação do MAC na superfície da célula alvo promovendo a eliminação do patógeno (AlonsoDeVelasco et al., 1995). A deficiência de C3 na paciente A.S.S e consequentemente de seus fragmentos pode ser uma das causas que permitiram a evolução do quadro clínico para pneumonia, uma vez que o sistema complemento tem um importante papel na resposta imune inata contra $S$. pneumoniae e na paciente esse sistema é deficiente. 
Figura 15 - Modelo baseado na estrutura cristalográfica da proteína C3

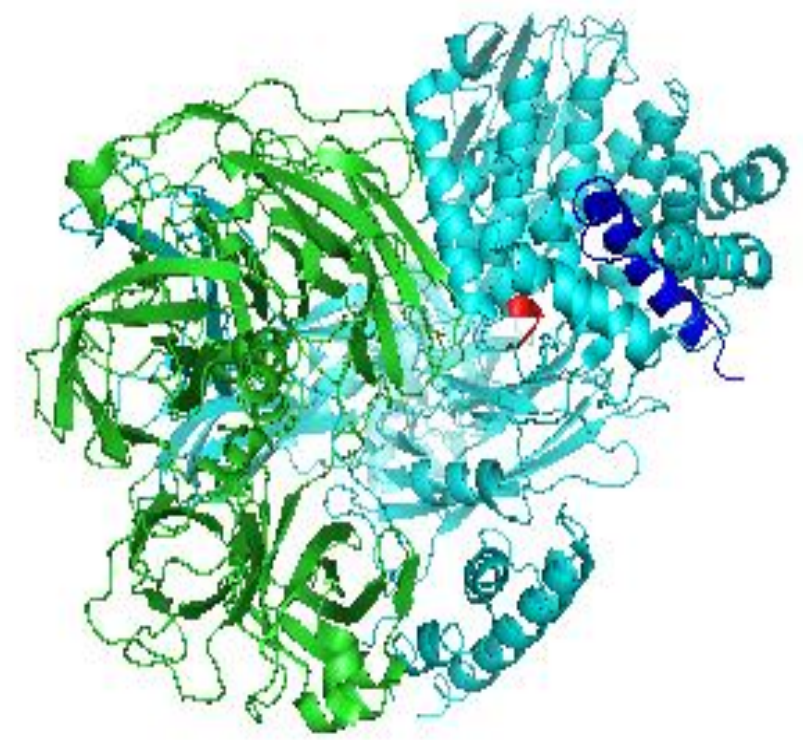

Em verde a cadeia $\beta$, em azul claro a cadeia $\alpha$, em vermelho a ligação tiól-éster, em azul escuro os 33 aa (posição 1131-1163) codificados pelo éxon 27. Figura feita utilizando o programa Pymol molecular graphis software. Fonte: Baseado em Janssen et al., 2005.

O processo de síntese e secreção de proteínas em células de eucariotos envolve vários mecanismos e o funcionamento defeituoso em qualquer um desses mecanismos pode causar a ausência da proteína no indivíduo. A síntese protéica adequada para ser completa depende da transcrição do gene, tradução do RNAm e seu endereçamento para os ribossomos. A análise do sequenciamento da região compreendida entre os nt 6690313 a 660961 do gene $C 3$ da paciente, mostrou a troca do nucleotídeo $\mathrm{T}$ por um $\mathrm{C}(\mathrm{T} \rightarrow \mathrm{C})$ na junção intrônica de splicing do éxon 27 (Figura 13) o que não acontece no indivíduo controle, e que acreditamos ser a causa da deficiência da proteína C3 na paciente por causar um splicing defeituoso que excluí o éxon 27 e a deleção de 33 aa na proteína $\mathrm{C} 3$.

$\mathrm{O}$ mecanismo de splicing é dependente do reconhecimento de pequenas sequências altamente conservadas localizadas nas extremidades éxon-íntron e no interior dos íntrons. Essas sequências são formadas por GT-AG para DNA, GU-AG (Figura 16) para pré-RNA no sentido $5^{\prime} \rightarrow 3^{\prime}$ do gene, e um ponto de ramificação onde se encontra uma adenosina no interior do íntron responsável por identificar o sítio de splicing 3'mais próximo como alvo para a ligação com o sítio de splicing 5'(Jurica, Moore, 2002). 
Figura 16 - Mecanismo de transcrição, splicing em RNAm e tradução para síntese proteica

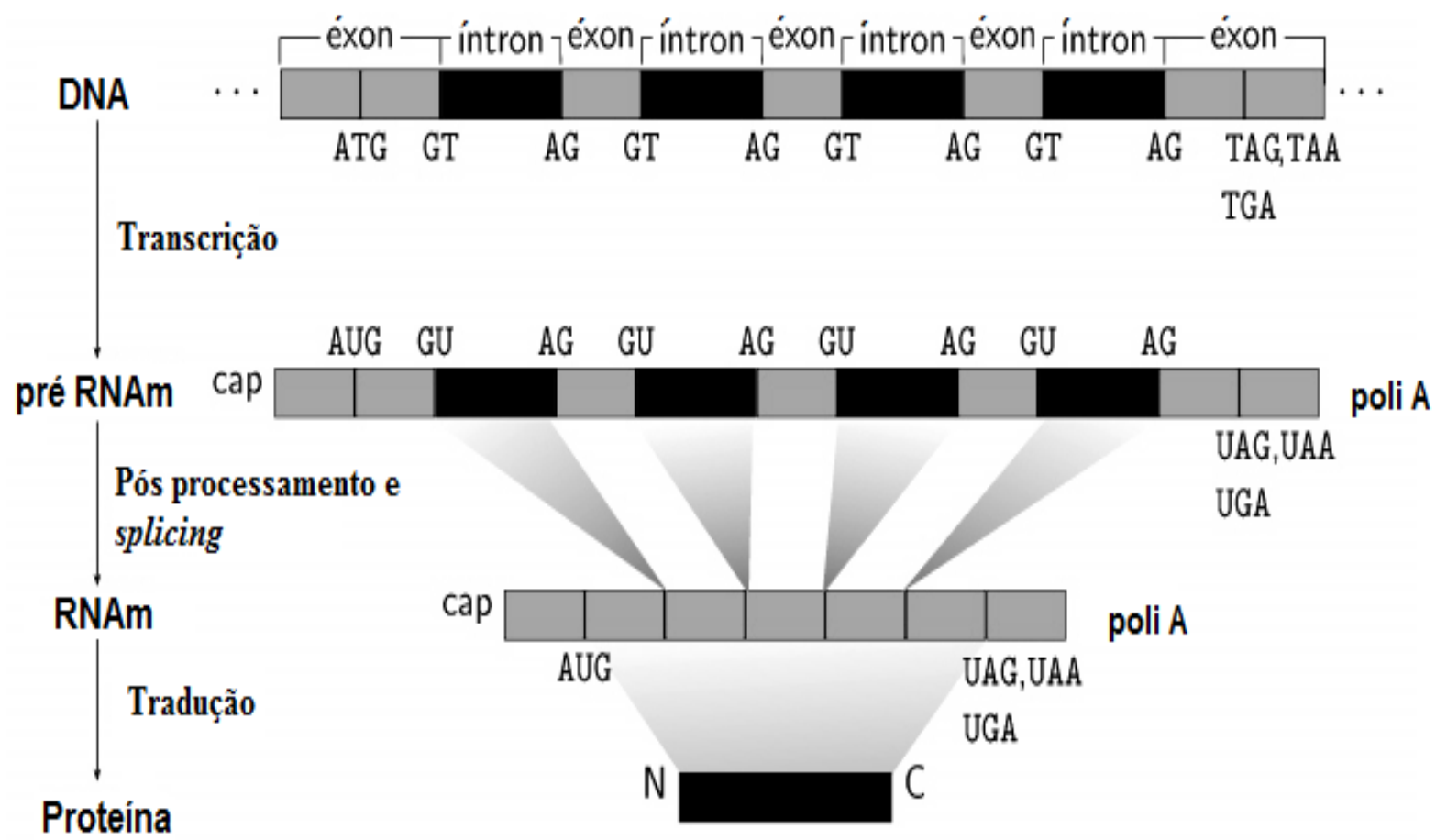

As bases GU-AG no pré-RNAm altamente conservadas nas extremidades íntron-éxon são reconhecidas durante o processo de splicing (exclusão do íntron) seguido da ligação de um éxon com o seguinte, formando o RNAm. Após a tradução do RNAm temos a síntese da proteína.

Fonte: Joseph et al., 2009.

Esse processo também envolve pequenos RNAs nucleares (snRNAs) denominados U1, U2, U4, U5, U6 e mais 60 polipeptídeos (Cartegni et al., 2002). Essas moléculas se agrupam a outras proteínas formando o spliceossomo responsável por reconhecer os locais de início e término dos íntrons removidos durante a transcrição. Proteínas reguladoras ( $\mathrm{SR}$ - das siglas em inglês $S$ para serina e $A$ para arginina) também controlam o mecanismo de splicing definindo os éxons e os íntrons que serão encaminhandos para o spliceossomo para clivagem do pré-RNAm em pontos específicos. As SR se ligam a esses pontos chamados ativadores exônicos de splicing (ESE - exonic splicing enhancers) nos nts, definindo o éxon alvo e recrutando os snRNAs U1 e U2 para o ponto de splicing nas extremidades dos íntrons adjacentes (Keren et al., 2010).

O U1 inicia o splicing reconhecendo as sequências altamente conservadas entre a extremidade $3^{\prime}$ do éxon e o GU da extremidade 5' do íntron, onde o pré-RNAm é cortado. Com o 
auxílio dos snRNAs U6 e U4 ocorre o dobramento do íntron formando uma alça (Figura 17). Esses snRNAs também recrutam outras proteínas dando origem ao spliceossomo que irá excluir os íntrons e unir os éxons para síntese do RNAm maduro (Keren, et al., 2010).

Durante esse processo, as SR podem agir reconhecendo e se ligando a sítios ativadores exônicos de splicing (ESE - exonic splicing enhancers) nos éxons para seu encaminhamento para o spliceossomo, ou a sítios intensificadores de splicing intrônico (ISE - intronic splicing enhancers) nos íntrons suprimindo esse íntron que será retirado do transcrito final. As ribonucleoproteínas heterogêneas nucleares (hnRNPs) podem atuar nessa fase se ligando a sítios de silenciamento exônico de splicing (ESS - exonic splicing silencers) ou ainda a sítios silenciadores de silenciamento intrônico (ISS - intronic silencing silencers) suprimindo um éxon ou íntron respectivamente (Keren, et al., 2010). 
Figura 17 - Representação do mecanismo de splicing

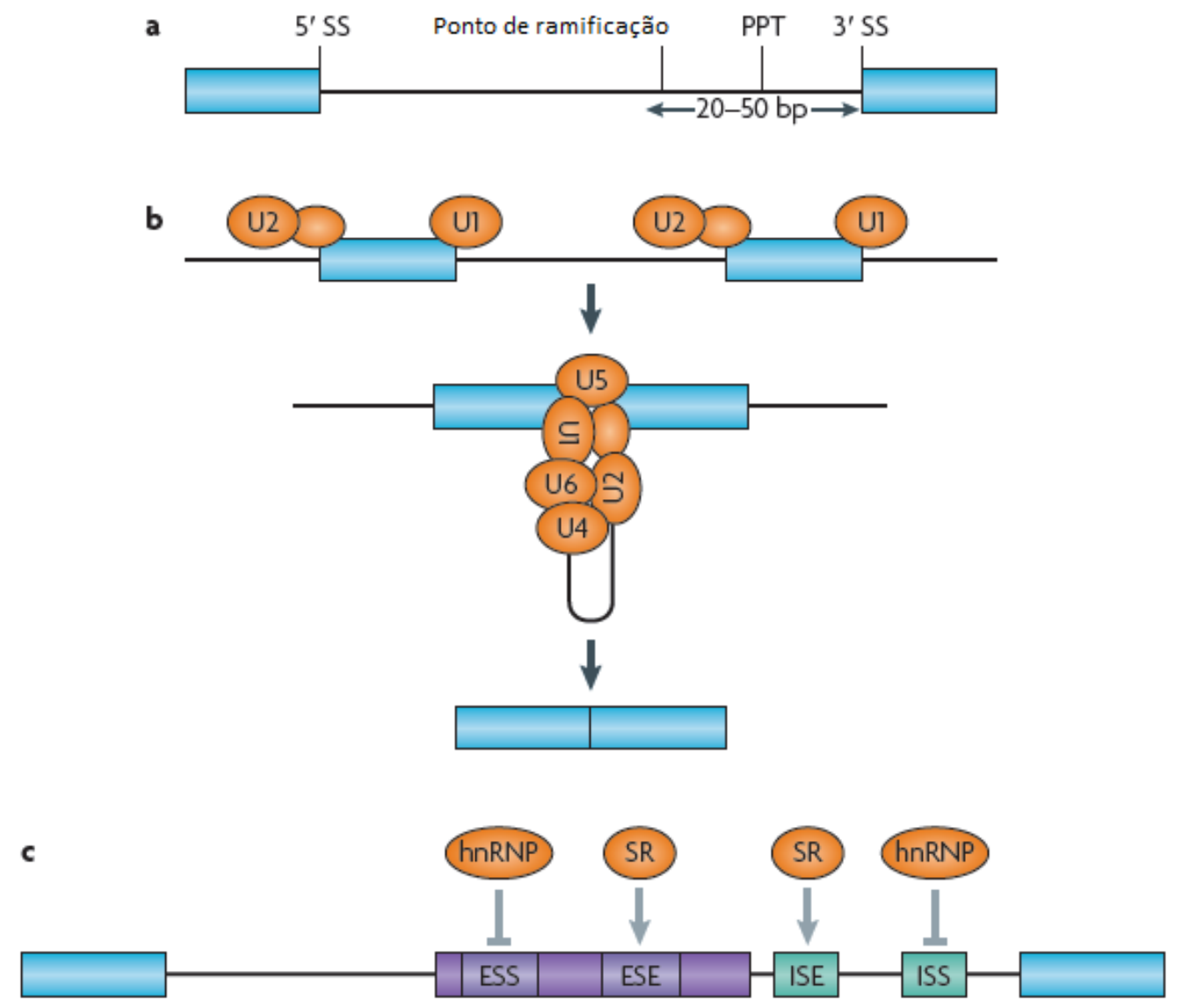

Em a temos os éxons constitutivos (azul) no sentido $5^{\prime} \rightarrow 3^{\prime}$. O sítio de splicing (SS) onde se encontram as sequências conservadas GT-AG (DNA) e GU-AG (RNA), o ponto de ramificação rico em pirimidina ou purina localiza-se 20-50 nt do sítio 3' onde também se localiza o trato polipirimidínico (PPT - polypyrimidine tract). Em b temos o reconhecimento das sequências conservadas GU-AG (RNAm) reconhecidas pelos pequenos RNAs nucleares U1 e U2 onde irão se ligar formar uma alça e remover íntron durante o splicing. Sinalização dos RNAs nucleares U1, U2, U5, U4 e U6 formando o spliceossomo que retita o íntron e une os éxons. Em c temos os éxons (roxo) com o Sítio de silenciamento exônico de splicing (ESS - exonic splicing silencers) onde a ribonucleoproteína heterogênea nuclear (hnRNPs) irá se ligar e sinalizar para a supressão do éxon. Sítio ativadores exônicos de splicing (ESE exonic splicing enhancers) onde a proteína reguladora (SR) irá se ligar para sinalizar o éxon que será encaminhado para o splaceossomo. Em verde temos os íntrons com o Sítio intensificador de splicing intrônico (ISE - intronic splicing enhancers) onde a SR se liga sinalizando o íntron que será encaminhado para o splaceossomo, e o Sítio silenciador de silenciamento intrônico (ISS - intronic silencing silencers) onde a hnRNPs irá se ligar e sinalizar para a supressão do íntron.

Fonte: Modificado de Keren et al., 2010.

Porém, uma falha nesse mecanismo de remoção dos íntrons pode gerar um RNAm anormal que é instável, uma sequência defeituosa ou uma isoforma protéica deletéria de uma proteína fundamental para o indivíduo. Mudanças no splicing de RNAm podem implicar em: a) exclusão ou inclusão de um éxon; b) mecanismo de splicing que reconhece pontos de splicing 
alternativo 3' para um íntron; c) mecanismo que reconhece os pontos de splicing alternativo 5'; d) exclusão de um ou mais éxons num sistema de exclusão mútua; e e) inclusão de um íntron que será mantido na transcrição final do RNAm (Cartegni et al., 2002).

Figura 18 - Formas de splicing alternativo em eucariotos

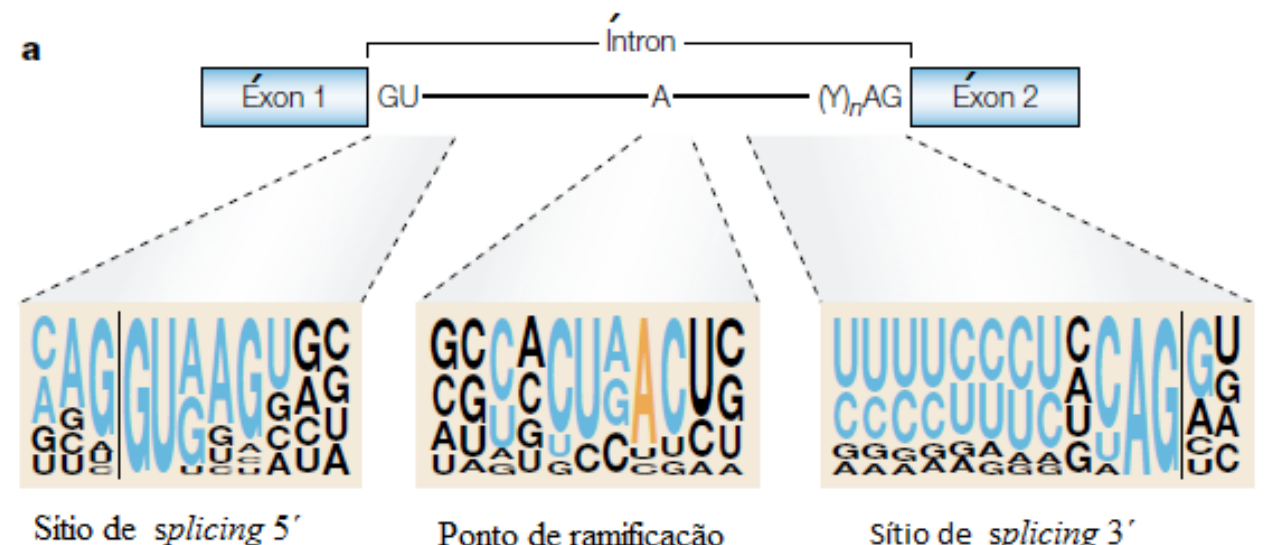

b

Inclusão/exclusão de éxon

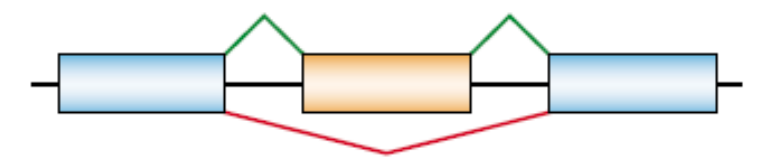

Sitio de splicing alternativo $3^{\prime}$

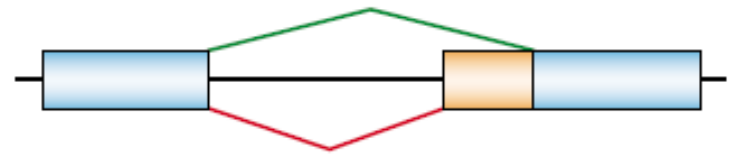

Sitio de splicing alternativo $5^{\prime}$

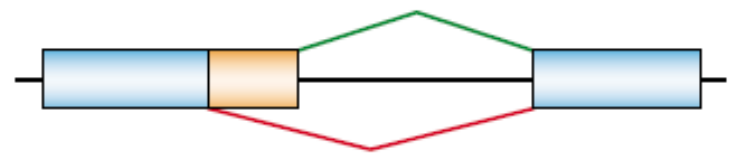

Exclusão mútua de éxon

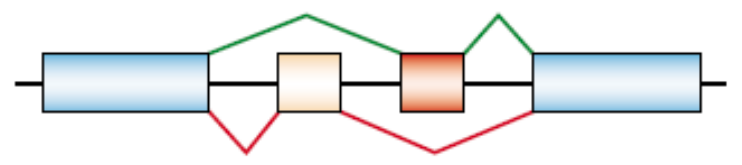

Retenção de intron

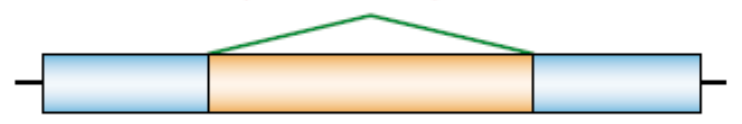

$\square$ Éxon $\quad \square \square$ Éxon de splicing alternativo

Em a temos uma figura esquemática das regiões reconhecidas durante o mecanismo de splicing alternativo e seus respectivos nucleotídeos (caixas = letras em formato maior são os nucleotídeos mais comuns encontrados nestas regiões e os menores são os que surgem com menor frequência). Em b temos as cinco formas mais comuns de splicing alternativo.

Fonte: Modificado de Cartegni et al., 2002. 
Nossos resultados mostram que a paciente possui uma troca de nucleotídeos $(\mathrm{T} \rightarrow \mathrm{C})$ na região 6690626 do gene $C 3$ que leva ao não reconhecimento das sequências sinalizadoras intrônicas, gerando um splicing responsável pela exclusão do éxon 27 no pré-RNAm de C3. O U1 responsável por clivar o pré-RNAm de C3 entre a extremidade 3' do éxon e o GU da extremidade $5^{\prime}$ do íntron não é capaz de exercer sua função uma vez que ela não reconhece a sequência GC presente na paciente. Quando esse splicing inadequado acontece gerando a tradução de um RNAm mutado que posteriormente implicará em diferença de 33 aa (posição 1131 até 1163 na proteína) codificados pelo éxon 27 excluído, isso dará origem a uma proteína mutante que pode ser degradada ainda dentro da célula. Isaac e Isenman (1992) mostraram que proteínas mutantes de C3 incapazes de formar a ligação tiól-éster podem ser instáveis e susceptíveis à degradação intra-celular. Como o éxon 27 está localizado dentro do domínio TED (963-1268 aa) abrangendo parte do domínio CUB (912-962 aa e 1269-1330 aa) (Figura 7) em uma região altamente conservada, a deleção desses 33 aa poderia significar uma mudança conformacional prejudicial reduzindo o espaço físico de interação entre os domínios que poderiam comprometer o domínio TED com consequente formação de uma proteína C3 mutante instável que é rapidamente degradada, não sendo secretada para o meio extracelular, conforme observado na Figura 14.

Nosso grupo também demostrou o caso de um rapaz então com 19 anos de idade deficiente do componente $\mathrm{C} 5$ do complemento. O sequenciamento do cDNA de C5 mostrou a deleção de 153 pb correspondentes aos nucleotídeos 3877-4029 codificados pelo éxon 30. Depois da análise do sequenciamento do gene $C 5$ das regiões entre os éxons 29 e 31, constatou-se a substituição de uma base $\mathrm{C} \rightarrow \mathrm{G}$ na posição 31055723 no íntron 30 do gene $C 5$, responsável pela deficiência desta proteína no paciente (Ramirez-Aguilar et al., 2009). Semelhante ao nosso caso, esse paciente deficiente de C5 possui uma mutação que leva a deleção de um éxon inteiro, porém difere quanto à sequência e a troca do nucleotídeo na região intônica do pré-RNAm de C5.

Acreditamos que a mutação no RNAm de C3 da paciente A.S.S possa gerar a síntese de uma sequência mutate devido a deleção do éxon 27 e uma conformação estrutural diferente, o que pode levar a sua degradação ainda dentro da célula. O exossomo é um grande complexo protéico formado por exonucleases em associação. Este complexo é capaz de degradar o préRNAm que não sofreu um splicing adequado eliminando possíveis defeitos genéticos. Uma vez que este RNAm mutado (devido à ausência do éxon 27 no caso da paciente em estudo) é 
processado, possivelmente ele poderia ser reconhecido ainda no núcleo pelo exossomo e degradado, e dessa forma o RNAm mutado não seguiria para o processo de tradução, interrompendo a síntese protéica (Schmid et al., 2008).

A tradução de um RNAm mutado poderia também representar como consequência a síntese de uma proteína truncada que pode não ser reconhecida pelas chaperonas, causando um não dobramento protéico adequado com posterior degradação. Esta proteína truncada pode ainda ser marcada pela ubiquitina e endereçada para degradação no proteossoma, ou a síntese de uma proteína truncada pode acabar levando ao seu aprisionamento dentro da célula (Katz et al., 1994).

Dos 31 casos aqui descritos de pacientes deficientes de $\mathrm{C} 3 \mathrm{em}$ que as bases moleculares foram desvendadas, 7 deles tratam de alteração de nucleotídeos que levam a um códon de parada prematura e ausência da proteína, porém cada caso é único, confome comentado anteriormente (1.10 página 35). Em todos os relatos de deficientes de $\mathrm{C} 3$ foram descritas mutações em regiões distintas do gene $C 3$, mostrando a individualidade de cada deficiência descrita. Nosso trabalho mostrou algo inédito, a troca de nucleotídeos $(\mathrm{T} \rightarrow \mathrm{C})$ na região 6690626 do gene $C 3$ jamais descrita antes para esta deficiência. Isso torna o nosso achado ainda mais interessante para a compreensão das bases moleculares das imunodeficiências, um passo necessário para o estudo de futuras terapias na tentativa de melhora e promover uma melhor qualidade de vida para esses pacientes. Além disso, a investigação dessa área tem um potencial para ajudar a elucidar ainda mais a função e a relação do sistema complemento com as imunodeficiências a ele ligadas. 


\section{CONCLUSÕES}

1- A proteína C3 está ausente no soro da paciente, confirmada por imunodifusão e por ensaios hemolíticos que mostraram a incapacidade de seu soro em lisar as hemácias utilizadas neste ensaio.

2- O sequenciamento genético das regiões 6690313 até 6690961 do gene $C 3$ confirmou a heterozigose dos pais, e do irmão para a mutação presente na paciente que se mostrou homozigota para tal mutação.

3- Identificarmos a completa deleção do éxon 27 no RNAm de C3 da paciente, responsável pela codificação de 33 aa no domínio TED da proteína C3. A troca de nucleotídeos $(\mathrm{T} \rightarrow \mathrm{C})$ na região 6690626 do gene $C 3$ leva ao splicing defeituoso que exclui o éxon 27, gerando uma proteína instável sendo, portanto a causa da deficiência da proteína C3 do complemento na paciente. 


\section{REFERÊNCIAS*}

Agarwal S, Specht CA, Huang H, Ostroff GR, Ram S, Rice PA, Levitz SM. Linkage specificity and role of properdin in activation of the alternative complement pathway by fungal glycans. Mbio. 2011;2:1-10.

Ahearn JM, Fearon DT. Structure and function of the complement receptors, CR1 (CD35) and CR2 (CD21). Adv. Immunol.1989;46:183-19.

Aleshin AE, Schraufstatter IU, Stec B, Bankston LA, Liddington RC, DiScipio RG. Structure of complement C6 suggests a mechanism for initiation and unidirectional, sequential assembly of membrane attack complex (MAC). J Biol Chem. 2012;287(13):10210-22.

AlonsoDeVelasco E, Verheul AFM, Verhoef J, Snippe H. Streptococus pneumoniae: virulence factors, pathogenesis, and Vaccine. Microbiol Rev. 1995;59(4):591-03.

Alper CA, abramson N, Johnston RB Jr, Jandl JH, Rosen FS. Studies in vivo and in vitro on an abnormality in the metabolism of C3 in a patient with increased susceptibility to infection. J Clin Invest. 1970; 49(11): 1975-85.

Alper CA, Colten HR, Rosen FS, Rabson AR, Macnab GM. Homozygous deficiency of C3 in a patient with repeated infections. Lancet. ii: 1972;1179-81.

Alper CA, Rosen FS. Genetics of the complement system. Adv Hum Genet. 1989;7:88-41.

Altschul SF, Madden TL, Schaffer AA, Zang Z, Miller W, Lipman DJ. Gapped BLAST and PSIBLAST: a new generation of protein database search programs. Nucleic Acids Res. 1997;25:3389-3402.

Amara U, Flierl M A, Rittirseh D, Klos A. Chen H, Acker B, Bruckner BU, Nilsson BO, Gebhard F, Lambris J D, Lang MH. Molecular intercommunication between the complement and coagulation Sistems. J Imunol . 2011;185:5628-36.

Ballow M, Shira JE, Harden L, Yang SY, Day NK. Complete Absence of the third component of complement in Man. J. Clin. Invest. 1975;56:703-10.

Barrett DJ, Boyle MD. Restoration of complement function in vivo by plasma infusion in factor I (C3B) inactivator deficiency. J Pediatr. 1984;104(1):76-81.

*De acordo com: International Committee of Medical Journal Editors. [Internet]. Uniform requirements for manuscripts submitted to Biomedical Journal: sample references. [updated 2011 Jul 15]. Available from: http://www.icmje.org 
Berger M, Balow JE, Wilson CB, Frank MM. Circulating immune complex and glomerulonephritis in a patient with congenital absense of the third component of complement. New England J Med. 1983;308: 1009-12.

Berman S, Gewurz H, Mold C. Binding of C-Reative protein to nucleated cell leads to complement activation without citolysis. J Imunol. 1986;136(4):1354-64.

Bhakdi S, Bhakdi-Lehnen B, Bjerrum OJ, Tranum-Jensen J. Diference in antigenic reactivity and ultrastructure between fluid-phase C5b-9 and the C5b-9 membrane attack complexof human complement. Febs Lett. 1979;1:15-19.

Bhide SS. Recurrent meningitis in a family with C3 deficiency. Letter to the Editor. Indian Pediatr. 2006;43:269-270.

Bird P, Lachmann PJ. The regulation of IgG subclass production im man: low serum igG4 in inherited deficiencies of the classical pathway of C3 activation. Eur J Immunol.1998;18(8):121722.

Bohnsack JF, Cooper NR. CR2 ligands modulate human B cell activation. J. Immunol.1988; 141(8)2569-76.

Bokisch VA, Müller-Eberhard HJ. Anaphylatoxin inactivator of human plasma: its isolation and caracterization as a carboxypeptidase. J Clin Invest. 1970;49:2427-36.

Borzy MS, Gerwurz A, Wolff L, Houghton D, Lovrien E. Inherited C3 deficiency with recurrent infections and glomerulonephritis. Am J Dis Child. 1988;142:79-83.

Borzy MS, Houghton D. Mixed-pattern immune deposit glomerulonephritis in a child with inherited deficiency of the third component of complement. Am. J Kidney Dis. 1985;5(1): 54-59.

Botto M, Fong KY, SO AK, Rudge A, Walport MJ. Molecular basis of hereditary C3 deficiency. J Clin Invest. 1990;86:1158-63.

Botto M, Fong KY., SO, A.K., BARLOW, R., ROUTIER, R., MORLEY, B J. Homozygous hereditary C3 deficiency due to a partial gene deletion. Proc. Natl. Acad. Sci. 1992; USA 89:4957-61.

Bresson S M, Conrad, NK. The human nuclear poly(A)-binding protein promotes RNA hyperadenylation and decay. PLOS Genetics. 2013; 9(10):1-17.

Bruji MHL, Fey GH. Human complement component C3: cDNA coding sequence and derived primary structure. Biochemisty. 1985; 84:708-12.

Campbell RD., Booth, NA., FothergilL, JE. Purification and Characterization of Subcomponent C1s of the First Component of Bovine Complement. Biochem. J. 1979; 183:579-88. 
Carrol MC. The Role of Complement receptors in induction and regulation of immunity. Immunology. 1998;16:545-68.

Cartegni L, Chew SL, Krainer AR. Listening to silence and understanding nonsense: exonic mutations that affect splicing. Nat Rev Genet. 2002;3(4):285-98.

Carter RH, Fearon DT. CD19: lowering the threshold for antigen receptor stimulation of B lymphocytes. Science. 1992;256(5053):105-07.

Catterall FC, Lyons, A, Sim B R., DAY, J A., HARRIS, R J T. Characterization of the primary amino acid sequence of human complement control protein Factor I fron an analysis of cDNA clones. Biochem. J. 1987;242:849-56.

Chen M, Daha MR, Kallenberg CGM. The complement system in systemic autoimmune disease. J Autoimmun. 2010;34:j276-82.

Chirgwi JM, Przbyla AE, Macdonal RJ, Rutter WJ. Isolation of biologically active ribonucleic acid from sources enriched in ribonuclease. Biochemistry. 1979;18:5294-49.

Cole FS, Mattehews WJ, Marino JT, Gash DJ, Colten HR. Control of complement synthesis and secretion in bronchoalveolar and peritoneal macrophages. J Immunol. 1980; 125(3):1120-24.

Cornacoff JB, Hebert LA, Smead WL, Vanaman ME. Primate erythrocyte- immune complexclearing mechanism. J. Clin. Invest. 1983;71:236-47.

Cozma G, Aburumeih S, Mallk-Cozma MC, Johny KV. CAPD in a patient with complete absence of C3. Clin. Nephrol. 1987;27(5):269.

Croix DA, Ahearn JM, Rosengard AM, Han S, Kelsoe G, Ma M, Carroll, MC. Antibody Response to a T-dependent Antigen Requires B Cell Expression of Complement Receptor. J Exp Med. 1996; 183:1857-64.

Czop J, Nussenzweig V. Studies on the mechanism of solubilization of immune precipitates by serum. J Exp Méd. 1976;143;615-30.

Daffern PJ, Pfeifer PH, Ember JA, Hugli TE. C3a is a chemotaxian for human eosinophils but not for neutrophils. I C3a stimulation of neutrophils is secondary to eosinophil activation. J Exp Med. $1995 ; 181: 2119-27$.

Dahl MR, Thiel S, Matsushita M, Fujita T, Willis AC, Christensen T, Vorup-Jensen T, Jensenius JC. MASP-3 and its association with distinct complexes of the mannan-binding lectin complement activation pathway. Immunity. 2001;15(1):127-35.

Davies ME, Schifferli JA, Walport MJ. Complement deficiency and immune complex disease. Springer Semin Immunopathol. 1994;15(4):397-16. 
Davis AE, Davis JS, Rabson AR, Osofsky SG, Colten HR, Rosen FS, Alper CA. Homozigous C3 deficiency: detection of C3 by radioimmunoassay. Clin Immunol. Immunop. 1977;8: 543-550.

De Bruijn MHL, Fey C H. Human complement component C3: cDNA coding sequence and derived primary structure. Proc. Natl. Acad. Sci. USA. 1985;82:708-12.

Dempsey PW, Allison MED, Akkaraju S, Goodnow CC, Fearon DT. C3d Complement as a Molecular Adjuvant: Bridging Innate and Acquired Immunity. Science. 1996;271:348-50.

Elsner J, Oppermann M, Czech W, Kapp A. C3a activates the respiratory burst in human polymorphonuclear neutrophilic leukocytes via pertussis toxin-sensitive G-proteins. Blood. 1994;83(11): 3324-31.

Endo Y, Takahashi M, Iwaki D, Ishida Y, Nakazawa N, Kodama T, Matsuzaka T, Kanno K, Liu Y, Tsuchiya K, Kawamura I, Ikawa M, Waguri S, Wada I, Matsushita M, Schawaeble WJ, Fujita T. Mice deficient in ficolin, a lectin complement pathaway recognition molecular, are suceptible to Streptococcus pneumoniae infection. J. Immunol. 2012;189: 5860-66.

Erdös EG, Sloane EM. An enzyme in human bloodplasma that inactivates bradykinin and kallidins. Biochem Pharmacol. 1960; 11:582-92.

Fearon DT, Austen F, Ruddy S. Properdin factor D: chacarterization of its sctive site and isolation of the precursor form. J. Exp. Med. 1974;139:355-66.

Fearon DT, Austen F. Properdin: binding to C3b and stabilization of the C3b-dependent C3 convertase. J. Exp. Med. 1975; 142:852-63.

Ferreira de Paula P, Barbosa JE, Junior PR, Ferriani VP, Latorre MRDO, Nudelman V, Isaac L. Ontogeney of complement regulatory proteins - concentrations of Fator H, Fator I, C4b-binding protein, properdin and vitronectin in healthy children of different ages and adults. Scand $\mathbf{J}$ Immunol. 2003;58:572-77.

FERREIRA DE PAULA, P. Intervalos de normalidade da concentração de algumas proteínas regulatórias do sistema complemento em crianças e adultos saudáveis brasileiros. 2003. 109 f. Dissertação (Mestrado em Imunologia - Instituto de Ciências Biomédicas, Universidade de São Paulo, São Paulo, 2002.

Ferriani VPL, Barbosa JE, Carvalho IF. Complement haemolytic activity classical and alternative pathaways, C3, C4 and factor B titres in healthy children. Acta Paediatr. 1999, 88:1062-66.

Ferries CT, Lachmann JP, Harrison AR. Analysis of the interactions between proprerdin, the third componebt of complement (C3), and its physiological activation products. Biochem. J. $1988 ; 252: 47-54$.

Francis K, van Beek J, Canova C, Neal JW, Gasque P. Innate Immunity and brain inflammation: the key role of complement. Expert Rev Mol Med. 2003; 5:1-19. 
Fritz B. What is clusterin? Clin Exp Immunol. 1992; 88:375.

Fujita T, Gigli I, Nussenzweig V. Human C4-binding protein: role in proteolysis of C4b by C3binactivator. J Exp Med. 1978; 148:1044-51.

Gerard, C, Hugli TE. Identification of classical anaphylatoxin as the des-Arg form of the C5a molecule: evidence of a modulator role for the oligosaccharide unit in human des-Arg ${ }^{74}-\mathrm{C} 5 \mathrm{a}$. Proc Natl Acad Sci USA. 1981; 78(3):1833-37.

Gigli I, Fujita T, Nussenzweig V. Modulation of the classical pathway C3 convertase by plasma proteins C4 binding protein and C3b-inactivator. Proc Natl Acad Sci USA. 1979;76: 6596-00.

Golan MD, Burger R, Loos M. Conformational changes in $\mathrm{Clq}$ after binding to immune complexes: detection of neoantigens with monoclonal antibodies. J Imunol. 1982; 129(2):445-47.

Grace HJ, Brereton-Stiles GG, Vos GH, Scholand M. A Family with partial and total deficiency of complement C3. S. Afr. Med. J. 1976;50:139-40.

Grumach AS, Vilela MM, Gonzalez CH, Starobinas N, Pereira AB, Dias-da-Silva W, CarneiroSampaio MM. Inherited C3 deficiency of the complement system. Brazilian J. Med. Biol. Res. 1988;21:247-57.

Hartmann K, Henz BM, Krüger-Krasagakes S, Köhl J, Burger R, Guhl S, Haase I, Lipper U, Zuberbier T. C3a and C5a stimulate chemotaxis of human master cells. Blood. 1997; 89 (8):2863-70.

Hazlewood MA, Kumararatne DS, Webster ADB, Goodall M, Bird P. An association between homozygous Ce deficiency and low levels of anti-pneumococcal capsular polysaccharide antibodies. Clin Exp Immunol. 1991;87(3):4004-09.

Helmy KY, Katschke KJJr,Gorgani NN, Kljavin NM, Elliott JM, Diehl L, Scales SJ, Ghilardi Nico, Campagne ML. CR1g: a macrophage complement receptor required for phagocytosis of circulating pathogenes. Cell. 2005;124:915-27.

Hsieh KH, Lin CY, Lee TC. Complete absence of the third component of complement in a patient with repeated infections. Clin. Immunol. Immunopathol. 1981;20(3):305-12.

Hugli TE. Structure and function of the anaphylatoxins. Springer. Semin. Immunopathol. 1984; $7(2-3): 193-19$.

Hung JL, Lin CY. A hereditary C3 deficiency due to aberrant splicing of exon 10. Clin Immunol Immunopathol. 1994;73(2):267-73.

Imai K, Nakajima K, Eguchi K, Endoh M, Tomino Y, Nomoto Y, Sakai H, Hyodo Y. Homozigous C3 deficiency associated with IgA nephropathy. Nephron. 1991;59:148-52. 
Isaac L, Isenman DE. Structure requirements thioester bond formaion in human complement component C3. J. Biol. Chem. 1992; 267(14):10062-69.

Janssen BJ, Gros P. Structural insights into the center complement component C3. Mol Immunol. 2007;44(1-3):3-10.

Janssen BJ, Huizinga EG, Raaijmakers HC, Roos A, Daha MR, Ekdahl KN, Nilsson- Ekdahl K, Nilsson B, Gros P. Strutures of complement component C3 provide insight sinto the function and evolution of immunity. Nature. 2005;437(22):505-11.

Jenne D, Stanley KK. Molecula cloning of S-proiein, a link between complement, coaglation and cell-substrate adhesion. EMBO J. 1985;12(4):3153-57.

Joseph R. Genetcs and Evolution of Life From Other Planets. Cosmology. 2009;1:150-200.

Jurica MS, Moose MJ. Capturing splicing complexes to study structure and mechanism. Methods. 2002; 28:336-45.

Kang YS, Do Y, Lee HK, Parck SH, Cheong C, Lynch RM, Loeffer JM, Steinmam RM, Parck CG. A dominant complement fixation pathway for pneumococcal polysaccharides initiated by SIGN-R1 interacting with C1q. Cell. 2006;125:47-58.

Kaplan MH, Volanakis JE. Interaction of C-reactive protein complexes with the complement system. I. Consumption of human complement associated with the reaction of C-reactive protein with pneumococcal C-polysaccharide and with the choline phosphatides, lecithin and sphingomyelin. J. Immunol. 1974; 112(6):2135-47.

Katz T, Singer L, Wetsel RA, Schlesinger M, Fishelson Z. Inherited complement C3 deficiency: a defect in C3 secretion. Eur J Immunol. 1994;24:1517-22.

Katz Y, Revel M, Strunk RC. Interleukin 6stimulates sybthesis of complement proteins factor B and C3 in human skin fibroblasts. Eur J Immunol. 1989; 19:983-88.

Katz Y, Wetsel RA, Schlesinger M, Fishelson Z. Compound heterozygoius complement C3 deficiency. Immunol. 1995;94:5-7.

Kemper C, Mitchell LM, Zhang L, Hourcade DE. The complement protein properdin binds apoptotic $\mathrm{T}$ cell and promotes complement activation and phagocytosis. Proc Natl Acad Sci USA. 2008;105 (26):9023-9028.

Kida M, Fujioka H, Kosaka Y, Hayashi K, Sakiyama Y, Ariga T. The first confirmed case with C3 deficiency caused by compound heterozygous mutations in the C3 gene: a new aspect of pathogenesis for C3 deficiency. Blood Cell Mol Dis. 2008;40:410-13.

Keren H, Lev-Maor G, Ast G. Alternative splicing and evolution: diversification, exon definition and function. Nat Rev Genet. 2010; 11(5):345-55. 
Korb LC, Ahearn JM. C1q binds directly and specifically to surface blebs of apoptotic human keratinocytes: complement deficiency and systemic lupus erythematosus revisited. J. Immunol. $1997 ; 158(10)$ 4525-28.

Kretzschmar T, Jeromin A, Gietz C, Bautsch W, Klos A, Kohl J, Rechkemmer G, BitterSuermann D. Chronic myelogenous leukemia-derived basophilic granulocytes express a functional active receptor for the anaphylatoxin C3a. Eur. J. Immunol. 1993; 23(2):558-61.

Lacroix BM, Aude CA, Arlaud JG. Colomb M. Isolation and functional chracterization of the proenzyme from of the catalytic domains of human C1r. Biochem. J. 1989;257:885-91.

Lambris JD. The multifunctional role of $\mathrm{C} 3$, the third component of complement. Immunol. Today. 1988;9(12):387-93.

Levin Y, Skidgel RA., Erdös EG. Isolation and caracterization of the subunits of human plasma carboxypeptidase N (kininase I). Proc Natl Acad Sci USA. 1982;79:4618-22.

Lublin DM, Atkinon PP. Decay-accelerating factor: biochemistry, molecular biology, and function. Annu. Rev. Immunol. 1989;7:35-58.

Mancini G, Carbonara AO, Hereremans JF. Immunochemical quantitation of antigens by single radial immunodifusion. Immunochemistry. 1965;3:235-64.

Manthey HD, Woodruff TM, Taylor SM, Monk PN. Complement component 5a (C5a). Int J Biochem Cell Biol. 2009;41(11):2114-7.

Martin DE, Zalman LS, Müller-Eberhard HJ. Induction of expression of cell superface homologous restriction factor upon anti-CD3 stimulation of human peritpheral lymphocytes. Immunology.1987;85:213-17.

Mastellos D, Papadimitriou JC, Franchini S, Tsonis PA, Lambris JD. A novel role of complement: mice deficient in the fifth component of complement (C5) exhibit impaired liver regeneration. J Immunol. 2001 Feb 15;166(4):2479-86.

Matsushita M, Endo Y, Fujita T. Complement-activating complex of ficolin and mannosebinding lectin-associated serine protease. J. Immunol. 2000;164:2281-84.

Matsushita M, Fujita T. Activation of the classical complement pathway by mannose-binding protein in association with a novel C1s-like serine protease. J.Exp. Med. 1992;176: 1497-02.

Matsuyama W, Nakagawa M, Hakashima, H, Muranaga F, Sano Y, Osame M. Identification of a novel mutation (Tyr1081Ter) in sisters with hereditary component C3 deficiency and SLE-like symptoms. Hum. Mut. 2000;17: 79. 
Matsuyama W, Nakagawa M, Takashima H, Muranaga F, Sano Y, Osame M. Molecular analysis of hereditary deficiency of theird component of complement (C3) in two sister. Internal Med. 2001;40(12):1254-1258.

Meri S, Morgan BP, Davies A, Daniel RH, Olavesen MG, Waldmann H, Lachmann PJ. Human protectin (CD59), an 18,000-20,000 MW complement lysis restricting factor, inhibits C5b-8 catalysed insertion of C9 into lipid bilayers. Immunology. 1990;71(1):1-9.

Mevorach D, Mascarenhas O, Gershov D, Elkon KB. Complement-dependent clearance of apoptotic cell by human macrophages. J Exp Med.1998;188(12)2313-20.

Milis L, Morris CA, Sheehan MC, Charlesworth JA., Pussel BA. Vitronectin-mediated inibition of complement: evidence for different binding sites for C5b-7 and C9. Clin Exp Immunol. 1993;92:114-19.

Mollnes TE, Song WC, Lambris JD. Complement in inflammatoryvtissue damage and disease. Trends Immunol. 2002;23(2):61-4.

Mousli M, Hugli TE, Landry Y, Bronner C. A mechanism of action for anaphylatoxin C3a stimulation of mast cells. J. Immunol. 1992;148(8):2456-61.

Murphy BF, Kirszbaum L, Walker ID, d'Apice AJF. SP-40,40, a Newly identified normal human serum protein found in the SC5b-9 complex of complement and in the immune deposits in glomerulonephritis. J Clin Invest. 1988;81:1858-64.

Nauta AJ, Castellano G, Xu W, Woltman AM, Borrias MC, Daha MR, Kooten C, Roos A. Opsonization whit $\mathrm{Clq}$ and manosse-binding lectin targets apoptotic cells to dendritic cell. J Imunol. 2004;173:3044-50.

Nilsson UR, Nilsson B. Simplified assays of hemolytic activity of the classical and alternative complement pathways. J Immunol. 1984;72:49-59.

OHTA, M., OKADA, M., YAMASHINA, I., KAWASAKI, T. The mechanism of carbohydratemediated complement activation by the serum mannan-binding protein. J. Biol. Chem. 1990;265(4):1980-84.

Okura Y, Yamada M, Takezaki S, Nawate M, Takahashi Y, Kida M, Kawamura N, Ariga T. Novel compound heterozygous mutations in the C3 gene: hereditary C3 deficiency. Pediatr Int. 2011;53:e16-e19.

Osofsky SG, Thompson BH, Lint TF, Gewurz H. Hereditary deficiency of the third component of complement in a child with fever, skin rash and arthralgias: Response to transfusion of whole blood. J. Pediatr. 1977;90:180-6. 
Pangburn KM, Schreiber DR, Müller-Eberhard JH. Human complement C3b inativador: isolation, characterization, and demonstration of an absolute requerement for the serum protein $\beta 1 \mathrm{H}$ for cleavage of C3b and cab in solution. J Exp Med. 1977;146:257- 70.

Pangburn MK, Müller-Eberhard JH. Relation of a puntative trioester bond in C3 to activation of the alternative pathway and the binding of $\mathrm{C} 3 \mathrm{~b}$ to biological targets of complement. J. Exp. Med. $1980 ; 152: 1102-14$.

Pangburn MK, Müller-Eberhard JH. The C3 convertase of the alternative pathway of human complement. Enzime properties of the biomolecular proteinase. Biochem J. 1986; 235:723-30.

Pangburn MK. Differences between the binding sites of the complement regulatory proteins DAF, CR1, and factor H on C3 convertases. J. Immunol. 1986;136(6):2216-21.

Peleg D, Harit-Bustan H, Katz Y, Peller S, Schlesinger M, Schonfeld S. Inherited C3 deficency and meningococcal disease in a teenager. Pediatr. Infect. Dis. J. 1992;11:401-04.

Pensky J, Hinz CF, Todd EW, Wedgwood RJ, Boyer JT., Lepow IH. Properties of highly purified human properdin. J. Immunol. 1968;100:142.

Pepys MB. Role of complement in induction of antibody production in vivo. J.Exp. Med. 974.140:126-45.

Podak ER, Müller-Eberhard JH. Isolation of human S-protein, an inhibitor of the membrane attack complex of complement. J. Biol. Chem. 1979;254(19):9808-14.

Potempa J, Korzus E, Travis J. The serpin superfamily of proteinase inhibitors: structure, function, and regulation. J. Biol. Chem. 1994;269(23):15957-60.

Prodinger W M. Complement receptor type two (CR2,CR21): a target for influencing the humoral immune response and antigen-trapping. Immunology. 1999;20(3):187-94.

Pussell BA, Nayef M, Bourke E, Morris S, Peters DK. Complement deficiency and nephritis: A report of a family. Lancet. 1980;I:675-77.

Ramirez-Aguilar P, Reis ES, Florido MPC, Barbosa AS, Farah CS. Skipping of exon 30in C5 result in complete human $\mathrm{C} 5$ deficiency and demostrates the importance of C5d and CUB domains for stability. Mol Immunol. 2009;46:2116-23.

Reis ES, Falcão DA, Isaac L. Clinical Aspects Molecular Basis of Primary Deficiencies of complement Component C3 and its Regulatory Proteins Factor I and Factor H. Scand J. Immunol. 2006;63(3): 155-68.

Reis ES, Barach GV, Lima AS. Homozygous hereditary C3 deficiency due to a premature stop códon. J Clin Immunol. 2002;22(2):321-29. 
Reis ES, Barbuto AM, Isaac L. Human monocyte-derived dendritic cells are a source of several complement proteins. Inflamm Res. 2006;55(5):179-84.

Reis ES, Barbuto AM, Isaac L. Complement componentes, regulators and receptores are produced by human monocyte-derived dendritic cells. Immunoloy. 2007; 212(3):151-57.

Reis ES, Barbuto AM, Isaac L. Impaired dendritic cell differentiation and maturation in the absence of C3. Mol Immunol. 2008;45(7):1952-62.

Reis ES, Falcão DA, Isaac L. Clinical aspects molecular basis of primary deficiencies of complement component C3 and its regulatory proteins Factor I and Factor H. Scand J Immunol. 2006;63:155-68.

Reis ES, Nudelman V, Isaac L. Nonsense-codon-mediated decay in human hereditary complement C3 deficiency. Immunogenetics. 2004;55(10):667-73.

Rezende MS, Elizabeth R, Lane DA. Coagulation, inflamation, and apoptosis: diferente roles for protein S and protein S-C4b binding protein complex. Blood. 2004;103: 1192-00.

Rhichard JQ, Nichoson-Weller A, Cybulsk AV, Badalamenti J, Salant DJ. Decay accelerating factor regulates complement activation on glomerular epithelial cells. J Imunol. 1989;142:877-82.

Ricklin D, Hajisshengalli G, Yanag K, Lambris J. Complemetn: a key system for immune surveillance ans homeostasis. Nat Immunol. 2010;11(9):785-97.

Ripoche J, Day JA, Harris RJT, Sim BR. The complete amino acid sequence of human complement factor H. Biochem. J. 1988;249:593-02.

Rodriguez-Marco A, Bradbury M, Riley P, Arkwright PD. Autoimmunity and recurrent infections in partial complemente C3 immunodeficiency. Rheumatology. 2010;49:1017-19.

Roord JJ, Daha M, Kuis W, Verbrugh HA, Verhoef J, Zegers BJM, Stoop JW. Inherited deficiency of the third component of complement sssociated with recurrent pyogenic infections, circulating immune complex, and vasculitis in a dutch family. Pediatrics. 1983;71(1):81-7.

Sanal O, Loos M, Ersoy F, Kanra G, Ssemeer G, Tezcan I. Complement component deficiencies and infection: C5, C8 and C3 deficiencies in three families. Eur. J. Pediatr. 1992;151:676-79.

Sanchez-Corral P, Garcia C, Cordobas R. Isoforms of human C4b-binding protein, I: molecular basis for the C2BP isoform pattern and its variation in human plasma. J Imunol. 1995;155:403036.

Sano Y, Nishimukai H, Kitamura, H, Nagaki K, Inai S, Hamasaki Y, Maruyama I, Igata A. Hereditary deficiency of the third component of complement in two sisters with systemic lupus erythematosus-like symptoms. Arthritis Rheum - US. 1981;24:1255-60. 
Scharfstein J, Ferreira A, Gilgi I, Nussenzweig V. Humam C4-binding protein: Isolation and caracterization. J Exp Med. 1978;148:207-22.

Schmid M., Jensen TH. The exosome: a multipurpose RNA-decay machine. Trends Biochem Sci. 2008;33(10):501-510.

Seya T, Turner JR, Atkinson JP. Purification and characterization of a membrane portein (gp4570) that is a cofactor for cleavage of C3b and C4b. J Exp Med. 1986;163:837-55.

Shinkai Y, Takio K, Okumura K. Homology of perforin to the ninth component of complement (C9). Nature. 1988;334:525-27.

Sim RB, Arlaud GJ, Colomb MG. C1 inhibitor-dependent dissociation of human complement component C1 bound to immune complexes. Biochem J 1979;179(3):449-57.

Singer L, Hee MLV, Lokki MJ, Kramerb J, Borzy MS, Wetsel RA. Inherited complement C3 deficiency: reduced $\mathrm{C} 3 \mathrm{mRNA}$ and protein levels in a lotin kindred. Clin Immunol Immunopathol. 1996;81(3):244-52.

Singer L, Whitehead WT, Akama H, Katz Y, Fishelson Z, Wetesel R A. Inherited human complemen C3 deficiency. J Biol Chem. 1994;269(45):28494-99.

Singh DK, Rai R. Recurrent meningitis secondary to isolated C3 deficiency. Indian J Pediatr. 2009;76:95-96.

Snyderman R, Phillips JK, Mergenhagen SE. Biological activity of complement in vivo. Role of $\mathrm{C} 5$ in the accumulation of polymorphonuclear leukocytes in inflammatory exudates. J Exp Med. 1971;134(5):1131-43.

Suresh M, Molina h, Salvato MS, Mastellos D, Lambris JD, Sandor M. Complement component 3 is required for optimal expansion of CD8 T cell during a systemic viral infection. J Immunol. 2003; 170:788-94.

Takabayashi T, Vannier E, Clark BD, Margolis NH, Dinarello CA, Burke JF, Gelfand JA. A new biologic role for $\mathrm{C} 3 \mathrm{a}$ and $\mathrm{C} 3 \mathrm{a}$ desArg: regulation of TNF-alpha and IL-1 beta synthesis. J. Immunol. 1996;156(9):3455-60.

Takizawa F, Tsuji S, Nagasawa S. Enhancement of macrophage phagocytosis upon iC3b deposition on apoptotic cell. FEBS Lett.1996;397:269-72.

Tandon N, Morgan BP, Wetman AP. Expression and function of membrane attack complex inhibitory proteins on thyroid follicular cells. Immunology. 1992;75(2):372-377. 
Thiel S, Vorup-Jensen T, Stover CM, Schwaeble W, Laursen SB, Poulsen K, Willis AC, Eggeleton P, Hansen S, Holmskov U, Reid KB, Jensenius JC. A second serine protease associated with mannan-binding lectin that activates complement. Nature. 1997;386(6624):50610.

Trouw LA, Daha MR. Role of complement in innate immunity and host defense. Immunol Lett. 2011;138:35-37.

Tschopp J, Podack ER, Müller-Eberhard JH. The membrane attack complex of complement: C5b-8 complex as accelerator of C9 polymerization. J. Immunol 1985;134(1):495-99.

Tsukamoto H, Horiuchi T, Kokuba H, Nagae S, Nishizaka H, Sawabe T, Harashima S, Himeji D, Koyama T, Otsuka J, Mitoma H, Kimoto Y, Hashimura C, Kitano E, Kitamura H, Furue M, Harada M. Molecular analysis of a novel hereditary C3 deficiency with systemic lupus erythematosus. Biochem Bioph Res Co. 2005;330:298-04.

Ulbrich AG, Florido MPC, Nudelman V, Reis ES, Baracho G, Isaac L. Hereditary human complement C3 deficiency owing to reduced levels of C3 mRNA. Scand. J. Immunol. 2001; 53:622-26.

Vick DP, Amiquet P, Moffat GJ, Fey M, Barras FA, Wetesel RA, Tack BF. Structural feature of human $\mathrm{C} 3$ gene: intron/exon organization, transcriptional start site, and promoter region sequence. Biochemistry. 1991;30(4):1080-85.

Vyse TJ, Moley, BJ, Bartók I, Theodoridis ES, Davies KA, Webster DB. The molecular basis of hereditary complement factor I deficiency. J. Clin. Invest. 1996;97:925-33.

Waldmann H, Lachmann PJ. The failure to show a necessary role for C3 in the in vitro antibody response. Eur J Immunol. 1975; 5(3):185-93.

Walport M J. 2001. Complement. First of two parts. N Engl J Med. 2001;344(14):1058-66.

Wang XL, Li DJ, Yuan MM, Yu M, Yao XY. Enhancement of humoral immunity to the hCG $\beta$ protein antigen by fusing a molecular adjuvant C3d3. J Reprod Immunol. 2004;63;97-10.

Ware CF, Kolb WP. Assembly of the funcional membrane attack complex of human complement: Formation of disculfide-linked C9 dimer. Immunology. 1981;78 (10):6426-30.

Warren HB, Pantazis P, Davies PF. The Third Component of complement is transcribed and secreted by cultured human endothelial cell. Am J Pathol. 1987;129:09-12.

Weiss L, Ficher E, Cavaillon HN, Jouvin MH, Appay, MD, Bariety J, Kazatchkime M. The human C3b receptor (CR1). Adv Nephrol. 1989;18:249-70.

Weiss RM, Schulz EJ. Complement deficiency in Sweet's syndrome. Correspondense. 1989;41315. 
Whaley K, Ruddy S. Modulation of the alternative complement pathway by $\beta 1 \mathrm{H}$ globulin. J Exp Med. 1976;144:1147-63.

Whaley K. Biosynthesis of the complement components and the regulory proteins of the alternative complement pathaway by human peripheral blood monocytes. J Exp Med. 1980; 151:501-16.

Whitehead AS, Solomon E, Chambers S, Bodmer WF, Povey, S, Fey G. Assignment of the structural gene for the third component of human complement to chromosome 19. Proc Natl Acad Sci. 1982;79:5021-25.

Yonemasu K, Sasaki T, Shinkai H. Purification and characterization of subcomponent C1q of the first component of bovine complement. Biochem. J. 1980; 88(5):1545-54.

Young JDE, Cohn ZA, Podack ER. The ninth component of complement and the pore-forming protein (perforin I) from cytotoxic $\mathrm{T}$ cell: strutural, immunological, and functional similarities. Science. 1986;233:184-90.

Ziccardi RJ. A new role for C-1-inhibitor in homeostasis: control of activation of the first component of human complement. J. Immunol. 1982;128(6):2505-08.

Ziegler JB, Alper CA, Rosen RS, Lachmann PJ, Sherington L. Restoration by purified C3B inactivator of complement mediated function in vivo in a patient with $\mathrm{C} 3 \mathrm{~B}$ inactivator deficiency. J Clin Invest. 1975; 55(3): 668-72. 